UNIVERSIDADE DE SÃO PAULO

FACULDADE DE FILOSOFIA, LETRAS E CIÊNCIAS HUMANAS

DEPARTAMENTO DE GEOGRAFIA

PROGRAMA DE PÓS-GRADUAÇÃO EM GEOGRAFIA HUMANA

FLORA MEDEIROS LAHUERTA

\title{
Geografias em movimento: território e centralidade no Rio de Janeiro joanino (1808- 1821)
}

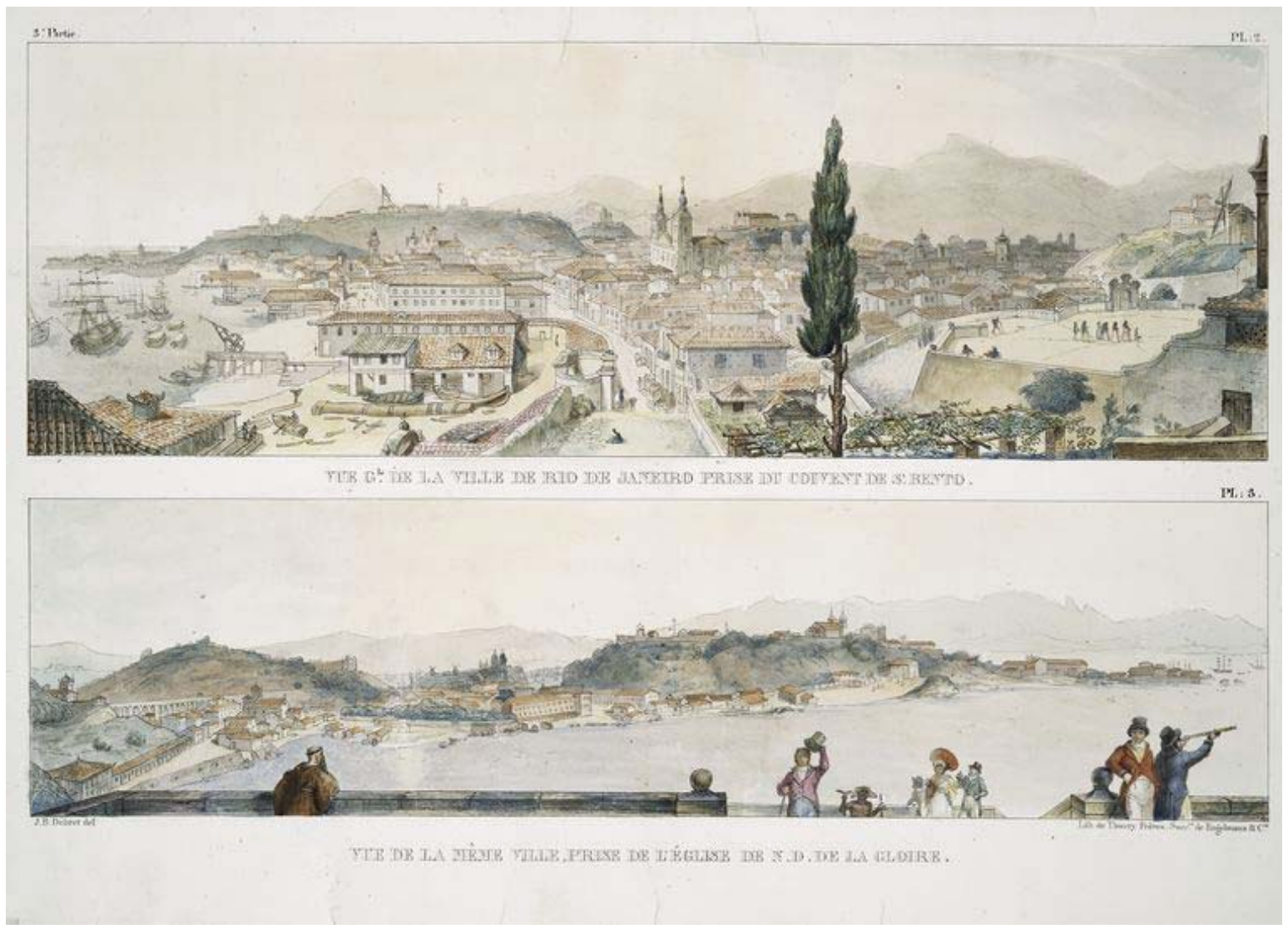

São Paulo, 2009 


\author{
UNIVERSIDADE DE SÃO PAULO \\ FACULDADE DE FILOSOFIA, LETRAS E CIÊNCIAS HUMANAS \\ DEPARTAMENTO DE GEOGRAFIA \\ PROGRAMA DE PÓS-GRADUAÇÃO EM GEOGRAFIA HUMANA
}

\title{
Geografias em movimento: território e centralidade no Rio de Janeiro joanino (1808- 1821)
}

FLORA MEDEIROS LAHUERTA

Dissertação apresentada ao

Programa de Pós-Graduação em

Geografia Humana da Faculdade de Filosofia, Letras e Ciências Humanas da Universidade de São Paulo, para a obtenção do título de Mestre em Geografia Humana

Orientador: Antonio Carlos Robert Moraes 


\title{
RESUMO
}

Pretendeu-se investigar, nesta dissertação, as transformações espaciais ocorridas no Rio de Janeiro no período em que a cidade foi morada da família real portuguesa (18081821), a partir de diferentes escalas. Primeiramente, a escala da cidade, centrando a análise nas adaptações e ajustes necessários para transformar uma cidade colonial em cidade de corte. Em seguida investiga-se a configuração da região polarizada pelo Rio de Janeiro, observando-se os mecanismos de ocupação do território e exploração dos sertões, através do estreitamento de interesses entre a elite local e os emigrados da corte. Por fim, analisa-se a cidade na escala de suas relações intercontinentais: tanto como a capital de um Reino espalhado por quatro continentes, quanto como um porto dinâmico, que se consolida como centro de uma vasta rede articulando fluxos continentais e marítimos. Esta experiência de quase inversão de papéis, ao transformar-se a antiga capital colonial em sede da monarquia portuguesa e de um grande Império, teve consequências consideráveis para o processo de independência do Brasil, que vislumbrou na vastidão e potencialidade do território um de seus alicerces principais.

Palavras-chave: geografia histórica, território, centralidade, Rio de Janeiro, período joanino

\begin{abstract}
This research tries to investigate the spatial changes that took place in the city of Rio de Janeiro during the stay of the Royal family, after escaping from Napoleon. The scale of the city itself is the subject of the first chapiter that focus on the adaptations and adjusts needed to transform the colonial city into a court city. On the following chapiter, the mechanisms of occupation of the region polarized by the city in analyzed, including the exploitation of the borders (sertões). Finally, we go back to the scale of the city, but now to think of it as an intercontinental port that articulates terrestrial and maritime fluxes, and also as the capital of a vast kingdom. This experience of changing roles between colony and metropolis had some important consequences to the process of independence developed in Brazil. A political process that considered the territory as one of its most valuable basis.
\end{abstract}

Key-words: historical geography, territory, centrality, Rio de Janeiro, d. João VI period 
Agradeço a Antonio Carlos Robert Moraes, pela orientação atenciosa, e a todos os demais professores e colegas que participaram direta ou diretamente deste processo.

Agradeço também à FAPESP (Fundação de Amparo à Pesquisa do Estado de São Paulo), que financiou a pesquisa de mestrado durante dois anos, cujo apoio foi fundamental para a realização deste trabalho.

$* * *$

Email: flora.ml@gmail.com 


\section{ÍNDICE}

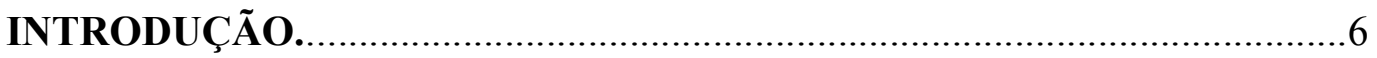

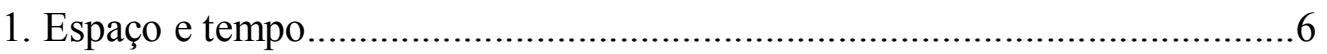

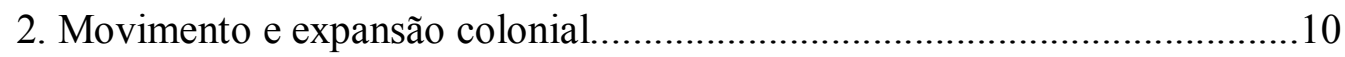

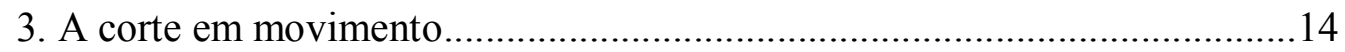

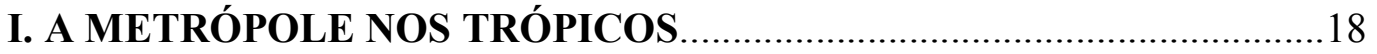

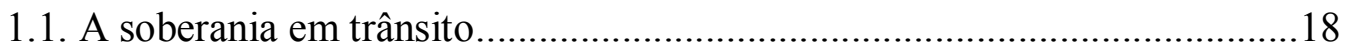

1.2 Abrindo as janelas: a cidade em transformação..........................................26

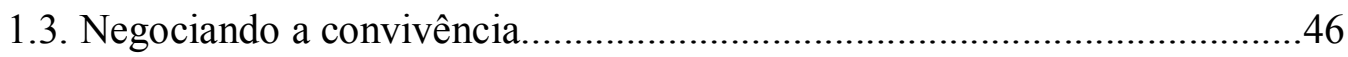

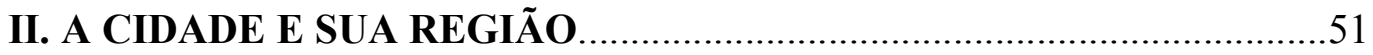

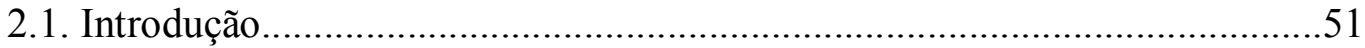

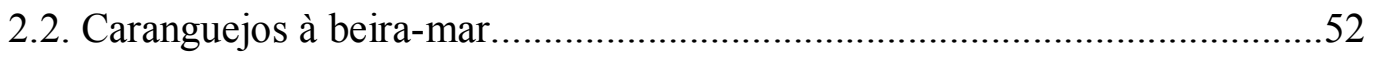

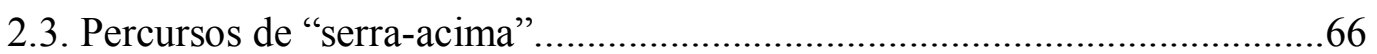

2.3.1. Entre pontes e desenganos....................................................... 72

2.3.2. Abrindo as portas do sertão..........................................................77

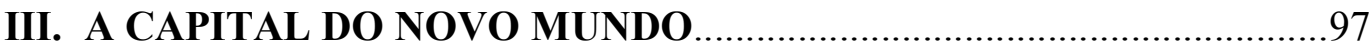

3.1. O Rio de Janeiro: olho do Brasil, cabeça do Império.....................................97

3.2. Os olhos sobre o Brasil: a paisagem, o mapa, o relato.................................107

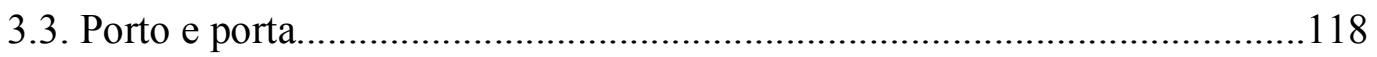

APONTAMENTOS FINAIS: TERRITÓRIO E CENTRALIDADE NO RIO DE JANEIRO JOANINO 


\title{
INTRODUÇÃO
}

\author{
"Cette allusion au mouvement est pour moi capitale \\ dès lors qu'il s'agit de géographie, car c'est en \\ verité le mouvement, l'action hors des espaces \\ familiers, qui est, depuis de siècles, la raison d'être \\ fondamentale de ce savoir"
}

Yves Lacoste (1990: 6)

\section{Espaço e Tempo}

A geografia foi por muito tempo identificada com o estudo de formas fixas, tais como elas se mostravam no presente. Maurício de Abreu (1995:14) chamou a atenção para este fato, demonstrando que a relação entre Geografia e História, enquanto duas disciplinas distintas, foi sempre pautada por uma necessidade de diferenciação, no intuito de delimitar bem as fronteiras de cada campo. Com isso, convencionou-se que estudo do presente caberia a uma e do passado à outra.

Pode-se dizer que esse traço se mantém até os dias de hoje, quando continua existindo uma grande dificuldade de diálogo, agravada pela disputa de legitimidade sobre a qual nos fala Pierre Bourdieu (2004). Mas o fato é que, apesar de certos "corporativismos" do campo seguirem vigentes, também existe uma tendência à interdisciplinaridade, que se manifesta não necessariamente no diálogo entre disciplinas, mas no compartilhamento de referências quando se trata de determinado assunto.

Essa tendência é perceptível, por exemplo, no aumento do interesse da teoria social pelo estudo do espaço, enquanto dimensão explicativa da sociedade. Edward Soja (1993) detecta este movimento, destacando Anthony Giddens, Michel Foucault e Henri Lefèbvre como exemplos de autores que se reportaram de alguma forma à dimensão espacial da sociedade, resgatando certos temas e conceitos da Geografia, e acabaram por influenciar novas pesquisas geográficas. 
O interessante é que esta "valorização" do estudo do espaço, ao estimular a incorporação de debates sociológicos e filosóficos pela geografia, não restringiu a percepção do tempo enquanto fator intrinsecamente relacionado à dimensão espacial, mas, pelo contrário, ressaltou a importância de quebrar a tradição kantiana de definição do espaço e do tempo enquanto categorias separadas. Reflexões atuais sobre a questão do espaço na "pós-modernidade" destacam a necessidade de se refletir sobre a realidade em termos de espaço-tempo (Harvey, 2002; Massey, 1994), vista a intrínseca inseparabilidade destas dimensões.

Mas pensando estritamente em Geografia História, enquanto sub-campo da Geografia, e apesar da referida tendência a aprisionar o estudo geográfico ao tempo presente, não é de hoje que se dá mais atenção à historicidade no estudo do espaço. Henry Clifford Darby (1983) cita um Atlas alemão de 1846 intitulado "The Historical Geography of the Holy Land" como um dos primeiros exemplos de utilização do termo. No século XIX, as mudanças nas fronteiras políticas e na extensão dos Estados motivavam estudos geográficos que dessem conta do processo formador dos territórios. No início do século $\mathrm{XX}$, as monografias da geografia clássica francesa tinham na contextualização histórica um de seus diferenciais, fruto das relações entre essa disciplina e a produção historiográfica da Escola dos Annales. A partir desse contato, pode-se afirmar que a geografia de Vidal de la Blache também teve grande influência sobre o trabalho de diversos historiadores, como Lucien Fèbvre, Fernand Braudel e Marc Bloch (Lira, 2008).

Justamente por essa tradição, os estudos geográficos da primeira metade do século XX sempre tinham um capítulo dedicado a uma reconstituição histórica do lugar estudado, antecedendo o estudo propriamente dito, que deveria ser composto por diversas observações empíricas e trabalhos de campo. Alan Baker (2003) destaca que é somente em meados dos anos 1950 que começa a aparecer uma produção bibliográfica atenta às questões da "Geografia Histórica" assim definida. Segundo ele, o resgate da historicidade torna-se necessário para entender o presente, mas não necessariamente toda geografia histórica tem que ser "retrospectiva", conforme pregam alguns autores, demasiadamente presos à idéia de geografia como ciência do presente. 
Já está claro que o presente está imbuído do passado. Conforme Carl Sauer (1991: 41), “cada paisagem humana, cada habitação, é sempre uma acumulação de experiência prática, e do que Pareto costumava chamar resíduos". Milton Santos, por sua vez, definiu o espaço como um "acúmulo de tempos" (1997), afirmando que na materialidade do espaço podem-se encontrar algumas chaves para o entendimento do passado. Entretanto, a geografia histórica não necessariamente necessita chegar ao estudo do contemporâneo, pois também pode se propor a entender o passado em sua própria complexidade, ou as transformações espaciais em um dado período, se diferenciando dos intuitos disciplinares da história pelo enfoque dado ao objeto de estudo.

Afinal, como afirma Baker (1997: 240, 241):

A geografia histórica é de fato um estudo histórico: seu foco de interesse repousa na geografia de algum tempo passado, ou nas mudanças geográficas em algum período passado. Assim, compartilha a legitimação intelectual e moral com todos os estudos históricos. Mas geografia histórica também é fundamentalmente um estudo geográfico: ela coloca questões geográficas ao passado, e oferece uma perspectiva geográfica sobre o passado. Sua contribuição distintiva ao conhecimento e entendimento do passado é feita essencialmente enquanto geografia e não história.

O resgate dessa historicidade do espaço é importante, pois a visão que aprisionava a geografia ao estudo do presente acabou por restringir muitos trabalhos a meras descrições. E mesmo depois de feita a crítica a esse tipo de estudo houve dificuldade teórica em formular uma associação entre espaço e tempo que ultrapassasse o nível do discurso, conforme lembra Milton Santos. Para este autor, a saída talvez estivesse em relacionar espaço e tempo enquanto categorias mutuamente includentes, que expressassem ao mesmo tempo uma concretude e uma idéia de processo. Afinal, "em qualquer momento, o ponto de partida é a sociedade humana em processo, isto é, realizando-se". Esta realização se dá, por sua vez, "sobre uma base material: o espaço e seu uso; o tempo e seu uso; a materialidade e suas diversas formas; as ações e suas diversas feições" (Santos, 2002a: 54)

Para David Harvey (2002), a discussão moderna sobre o espaço e o tempo tem raízes complexas, sendo toda ela permeada por um conflito entre o ser e o vir-a-ser. Nestas 
duas categorias filosóficas encontra-se a contradição entre o que é estático e o que flui. Essa contradição se tornou uma grande questão da modernidade: como dar conta do que muda incessante e rapidamente, como ter certezas se "tudo que é sólido desmancha no ar”? (Berman, 1986). As concepções sobre espaço e tempo na modernidade também vivenciaram este dilema: muitas vezes o tempo foi visto como fecundo, âmbito do possível, da criação, pela teoria social; e o espaço, por sua vez, visto como uma categoria ligada à estabilidade do lugar, materialidade inerte. Segundo a teoria crítica, no entanto, com a aceleração do tempo própria da modernidade este tempo se torna "espacializado", frente ao exagero da racionalização ${ }^{1}$, enquanto o espaço se "temporaliza" frente ao avanço fáustico do progresso.

Mesmo a constatação da fragilidade das certezas, provocada pela modernidade, não abala a idéia de um tempo linear e progressivo e de espaço inerte. Para Edward Soja (1993), a concepção de espaço como algo estático teria sido responsável pela falta de atenção das grandes teorias sociais, como o marxismo, para esta dimensão. Mesmo quando críticas à idéia de progresso, as variadas correntes de pensamento de inspiração marxista privilegiaram o tempo como categoria da revolução, da transformação, em detrimento da fixidez do espaço. Afinal, o caráter transformador do tempo, tão propagado pela modernidade capitalista, impregnou também a sua própria crítica.

Harvey demonstra como essa idéia de tempo tem origem no processo de "encolhimento" do mundo, graças ao avanço do capitalismo. Valendo-se da técnica, houve uma visão que defendia que o tempo acabava "aniquilando o espaço" pelo fim das distâncias, homogeneizando as diferenças. "A redução do espaço a uma categoria contingente está implícita na própria noção de progresso" (2002: 190), em que a idéia da flecha do tempo em direção ascendente se mostrava hegemônica. As raízes desse processo se encontram na Renascença e na produção de uma nova visão do espaço e do tempo, seja a partir das viagens que revelaram "um mundo finito e potencialmente apreensível" (Harvey, 2002: 221) seja a partir do desenvolvimento do cronômetro e sua possibilidade de medida do tempo linear e progressiva.

\footnotetext{
${ }^{1}$ Para Georg Lukács, o homem, em função da racionalização do processo produtivo, passa a ser mera "parte mecanizada" no sistema de reprodução, tornando-se a "carcaça do tempo". Junto com essa idéia o autor elabora que "o próprio tempo se torna abstrato perdendo sua qualidade mutável e fluida" e fixandose num continuum quantitativamente mensurável. Relacionando o aprisionamento do tempo com uma "espacialização do tempo", Lukács demonstra que o espaço sempre foi visto como rígido, estático.(1974:103).
} 


\section{Movimento e expansão colonial}

Antes que fosse apropriado de fato, o espaço potencial do globo foi apropriado na imaginação, a partir da incorporação de concepções científicas, como o perspectivismo ptlomaico, que permitiam a visão do globo como totalidade, "conquistável e contível para fins de ocupação humana" (Harvey, 2002: 225). Concepções estas necessárias para a justificativa dos empreendimentos marítimos de grande ambição. Na época das navegações, pensando do ponto de vista da descoberta da existência de "outros mundos", pode-se pensar num alargamento do mundo, extrapolando o umbigo mediterrâneo ${ }^{2}$. Esse movimento animado pelas trocas comerciais entre as revitalizadas cidades, envolvendo rotas que alcançavam China e Índia em busca de especiarias, coloca a geografia como "uma missão da Renascença" (Harvey, 2002, 224), a partir da incorporação e do conhecimento dos novos mundos, acompanhados de uma representação cartográfica re-elaborada por preceitos matemáticos nada fantasiosos.

Trata-se do expansionismo que está na origem das acumulações primitivas, antecipando o dinamismo capitalista, e trazendo uma centralização estatal necessária à organização dos estados territoriais, balizados pelas práticas mercantilistas de controle de rotas e produtos. "O controle do espaço está no centro das motivações do expansionismo quinhentista. O monopólio dos lugares - seja para produzir, comerciar ou simplesmente trafegar - era vital para o desenvolvimento das economias nacionais européias" (Moraes, 2000: 48)

Tendo isto em vista, a idéia de movimento colocada por Yves Lacoste na epígrafe desta introdução nos parece adequada para pensar a geografia, principalmente a geografia histórica, ou, melhor ainda, a geografia de países de passado colonial, como o Brasil, cuja formação deriva desse expansionismo. O movimento no espaço indica uma ação que é social e também temporal, ou seja, considera que as formas que se destacam no espaço são construídas e dotadas de historicidade. Não existe estudo do espaço possível sem a apreensão desta historicidade.

\footnotetext{
${ }^{2}$ Benedict Anderson acredita que é nesse contato com os "outros mundos" que se identifica o início de uma "territorialização da fé", o que geraria um sentimento inconsciente de identidade, semente do futuro nacionalismo. (1983: 12-18).
} 
Lacoste destaca a ação que se dá "fora de espaços familiares", mostrando que a meta do movimento se dá sobre novos espaços, mas sempre com o intuito de torná-lo conhecido. Para isso, se valem os exploradores das cartas geográficas, representações necessárias à familiarização do desconhecido. No caso de países de passado colonial, a construção do território se dá enquanto expansão e movimento, a partir de um outro país, o que implica o reconhecimento e ordenamento destas terras e homens. Segundo Douglas Santos, no processo de colonização do novo mundo descoberto, "há de construir-se uma nova geografia para que as terras novas deixem de ser novas e tornem-se uma extensão 'limpa' e 'segura' do 'velho' continente europeu” (Santos, D. 2002: 119).

Para Antonio Carlos Robert Moraes, “já em termos genéticos, a historia do Brasil remonta ao expansionismo lusitano. O país tem, por antecedente, o signo da conquista territorial"3. Ou seja, é a partir da colonização lusitana que se constrói o Brasil, "na apropriação de terras 'desconhecidas' dessa porção do Novo Mundo, na submissão das populações nativas defrontadas, na ocupação perene de certos lugares"4. Por este motivo, para este autor a geografia, enquanto apreensão deste processo, possui alto teor explicativo nas formações territoriais coloniais.

E se o expansionismo europeu, conforme citado anteriormente, constituiu uma característica de um período, aquele de transição do feudalismo para o capitalismo, a especificidade dos países ibéricos nesta empreitada merece ser ressaltada, uma vez que: “inventada, projetada e organizada por uma concepção espacial e territorialista, a América Ibérica não pode ser integralmente compreendida se a Ibéria não revelar suas entranhas"(Barboza Filho, 2000: 103). Inegável que a América se forma com contribuições das culturas indígenas e africanas, numa imbricação de valores, crenças, costumes. Mas se pensarmos na ação intencional do colonizador, com suas instituições e ordenamentos, podemos concluir, que a América é "medularmente ibérica".

Rubem Barboza Filho (2000) define a sociedade ibérica como intrinsecamente territorialista, característica peculiar que se perpetua em suas possessões coloniais, ainda que com inovações. Mesmo antes do impulso expansionista moderno, quando a glória

\footnotetext{
${ }^{3}$ Antonio C. R. Moraes. Ideologias geográficas. São Paulo, Hucitec, 1988, p. 94.

${ }^{4}$ Idem. Bases da formação territorial do Brasil, p. 410.
} 
de um Estado passou a ser associada a suas possessões (territórios e populações), esta característica já poderia ser percebida na Ibéria. Por isso é possível afirmar que:

"os ibéricos se empenharam em desenvolver, ao longo de quase um milênio, uma variante civilizacional do ocidente que tinha no espaço - metageograficamente entendido - a sua categoria básica e fundante. Durante séculos eles se movimentaram animados por uma fome insaciável de espaço, de novos territórios, consolidando o territorialismo como determinação intrínseca de suas formas de vida" (Barboza Filho, 2000: 14)

Tanto a crença na missão religiosa quanto a própria estrutura social ibérica contribuíram para a construção desta característica. Na tradição medieval ibérica, a legitimidade do Rei se pautava na distribuição de honrarias e riquezas, e não em sua capacidade de direcioná-las para a realização do monopólio da lei e da violência. O rei adorado era paternal, figura que emprestava algo da bondade divina, que distribuía riquezas, sem, no entanto, ferir os privilégios, jurisdições e direitos existentes. Sua figura poderia dar inicio a uma estratégia de centralização do poder, algo que lhe permitiria alterar de alguma forma a estrutura social. "Nas circunstâncias históricas da Ibéria medieval, entretanto, o rei só dispunha de uma saída: a expansão territorial e o avanço sobre outras sociedades, gerando novas ocasiões de agraciamento e novos recursos para a distribuição interna na ausência de um processo de acumulação do tipo capitalista" (Barboza Filho, 2000: 242).

Se a Guerra Santa e a Reconquista haviam representado episódios de incorporação de novos domínios ao âmbito cristão, a expansão territorial possibilitada pelo comércio e pelas grandes navegações possibilitou, para além da missão religiosa, a reiteração de um modelo rígido de organização social; um movimento que reforçava o imutável. Por este movimento, as tensões sociais eram empurradas para o limite da fronteira, sem que fossem postas em cheque. Desse modo, "Espanha e Portugal buscam o movimento e a expansão para se manterem idênticos, recusando, inibindo e extirpando possíveis elementos de mudança e alteração do quadro geral da sociedade" (Barboza Filho, 2000: 247).

Já se observou como os traços feudais se mantiveram na transição para o capitalismo, dominando as formas de poder. Afinal, conforme destaca Antonio Carlos R. Moraes, "a 
passagem de um modo de produção a outro desdobra-se com a convivência - muitas vezes associada - de relações próprias da ordem que se finda e da que emerge, alem de outras formas específicas geradas na transição"(Moraes, 2000: 33). No caso ibérico, o territorialismo e a preocupação com o controle social se perpetuaram através do desenvolvimento de meios para a preservação da ordem social. O papel do capital mercantil nesse caso é de realizar uma transformação na produção sem grandes mudanças.

Daí a ambigüidade: por um lado ele concretiza as condições prévias de instituição do novo modo de produção (ao mercantilizar a produção, monetizar as relações, expropriar, etc.), por outro constitui poderoso entrave à plena dominância do capital (ao sustentar privilégios, restringir a produção, barrar a circulação, etc.)(Moraes, 2000: 39).

Talvez seja um exagero dizer que Portugal e Espanha se mantiveram "idênticos" (Barboza Filho, 2000: 247). O próprio autor investiga como o Barroco foi a expressão de uma inovação, ainda que sujeita à reprodução da ordem hierárquica. Entende-se que se deve buscar ambas as dimensões dos processos sociais: tanto aquilo que remete à reiteração quanto o que permite o surgimento do novo. Ao analisarmos a sociedade colonial pela chave da sua espacialidade podemos nos deparar com certas heranças materializadas no espaço, que condicionam as ações, mas que também podem possibilitar novos usos.

Segundo Dodgshon (1998: 162), as sociedades teriam uma tendência à inércia, acentuada pelas estruturas espaciais. As mudanças, por este ponto de vista, sempre “envolvem uma interação entre passado e presente, não sendo apenas um 'olhar para frente', uma exploração sem custo das possibilidades presentes e de suas futuras potencialidades”. Milton Santos acrescenta que esta inércia do espaço seria dinâmica, pois imersa no constante movimento das sociedades, representando uma condição para uma eventual superação. "O processo social está sempre deixando heranças que acabam constituindo uma condição para novas etapas" (Santos, 2002a: 140) 


\section{Uma corte em movimento}

As invasões napoleônicas terão distintos efeitos sobre as colônias das metrópoles ibéricas invadidas. Na América Hispânica, a prisão do rei Fernando VII condiciona a uma crise sobre a legitimidade dinástica, o que acaba acarretando a irrupção de organizações autônomas, manifestas, por exemplo, nas proclamações de "cabildo aberto" como ocorreu em Buenos Aires e Caracas (Pimenta, 2002). Já em Portugal, a transmigração da Corte para o Brasil, em 1808, acaba trazendo para a colônia o projeto imperial lusitano, que tentou agregar as elites coloniais e propagar o expansionismo territorial, delegando a uma força central os poderes militares e enfraquecendo as iniciativas regionais (Jancsó, 2002).

Nas palavras de Rubem Barboza Filho: "enquanto o rex absconditus dos criollos tornase um rei inimigo, o rei português transubstancia-se para os brasileiros em rex praesens" (2000: 425). Este fato, o da vinda da família real portuguesa para a América, acabou motivando um desenrolar de uma história muito peculiar, em que a independência se fez sob a égide da monarquia e com a manutenção da escravidão, após a transformação da "periferia" em "centro".

Ou seja, era a primeira vez que a "parte" se colocava à frente do "todo". E, apesar da urgência com que foi tomada a decisão, a transferência da capital do império português para o Brasil, como colocado por Araújo, foi "singular, mas não acidental” (Araújo, 2005), uma vez que a idéia não representava nenhuma novidade para os estadistas portugueses.

A cidade do Rio de Janeiro, enquanto morada da família portuguesa, vivencia um momento de rupturas e inovações, que acabam levando a um processo de independência que se realiza, por sua vez, através da manutenção de certas heranças, como a monarquia, a escravidão e o vasto território em formação. O paradoxal é que, durante a estadia da corte na cidade, ao mesmo tempo em que se desejava apagar qualquer vestígio da antiga condição de colônia (mantendo-se porém a instituição da escravidão), procurava-se reiterar o Antigo Regime no Novo Mundo, numa articulação entre novo e velho que renovava certos princípios para poder perpetuar outros. Chegadas pela porta do porto do Rio de Janeiro, agora aberto às "nações amigas", idéias novas circulavam 
pelas ruas da cidade e, mesmo que se tentasse censurar livros e periódicos, era difícil conter sua propagação.

No primeiro capítulo, buscamos analisar como, com a transferência da corte para o Rio de Janeiro, foi necessária a construção de uma imagem positiva do Brasil, como representação da esperança de um grande e poderoso Império, frente aos tempos de crise. Com a chegada da família real à cidade do Rio de Janeiro pretendeu-se compreender, a partir da escala do habitat da realeza, sua Corte, as mudanças ocorridas na cidade para adequar-se ao status de morada do Príncipe Regente e da família real. Visto que, na sociedade de Corte, a casa do Rei era o centro de seu governo, a transferência da metrópole para uma colônia é, em si, um fato que gera a necessidade de inúmeros ajustes e readaptações. A questão da aparência, pelo viés espacial, é tratada aqui, relacionando-se a "abertura das janelas", simbólica e efetiva (com a remoção das rótulas) com a articulação entre as heranças espaciais a as novas materialidades.

Nesse lócus urbano que era agora a nova Corte é que se construirão as relações sociais entre os portugueses recém-chegados, os "reinóis", e a elite local, em grande parte ligada ao comércio e ao tráfico de escravos. A partir de uma investigação sobre estas relações se chega à segunda escala de análise proposta por este trabalho: a da cidade e sua região, investigando-se a ocupação da capitania do Rio de Janeiro através da doação de sesmarias para esta elite fluminense, fato em si representativo de um tipo de relação de reciprocidade que se estabeleceu entre os negociantes locais e o Príncipe Regente, e futuro Rei. No segundo capítulo, busca-se entender a intensificação das comunicações entre cidade e a capitania, agora dinamizada pela alta produtividade canavieira de Campos, a incipiente ocupação das terras do Vale do Paraíba, e o abastecimento proveniente de várias partes da capitania, e também do sul de Minas (Lenharo, 1992; Lobo, 1978; Lamego,1945, 1946, 1964). Esse processo, que constrói “pontes” entres os lugares, também "abre portas", como no caso dos "sertões do Macacu" na região de Cantagalo, tomados por garimpos clandestinos e tribos de "índios bravos" até o fim do século XVIII, quando se inicia o controle pela Coroa e se concedem sesmarias para a produção agrícola, como a do café.

Por fim, no último capítulo, pretendeu-se retornar à cidade, mas para pensá-la numa escala mundial. O Rio de Janeiro, descrito como "olho do Brasil" e "cabeça do 
Império", vivencia a elevação do Brasil a reino e a única aclamação de um rei europeu em terras tropicais. Investigam-se as consequências desta inversão de papéis, frente aos olhos do mundo. E se o Rio de Janeiro era o "olho do Brasil", ele passa a ser porta de entrada para os olhares que se estendiam pelo Brasil, leia-se os dos viajantes estrangeiros que adentravam pelos portos recém-abertos. A construção de imagens sobre o Brasil é também analisada no último capítulo, que se debruça sobre o porto do Rio de Janeiro em seu papel articulador de redes continentais e marítimas.

A centralidade que esta localidade, e conseqüentemente todo o Centro-Sul da colônia, adquire a partir do século XVIII é somente reforçada com a instalação da Corte portuguesa na cidade em 1808. As teorizações de Maria Odila Dias (1972) sobre a “interiorização da metrópole" abrem importante discussão sobre o papel de importância que adquire o Rio de Janeiro em relação às outras províncias, além de chamarem a atenção para a ampliação do aparato burocrático e mercantil que se dá na colônia. Logo, estudar o Rio de Janeiro no inicio do século XIX significa compreender a sua dimensão centralizadora de fluxos e redes continentais e marítimas, sendo estes tanto econômicos quanto políticos. Além disso, conforme coloca Ilmar Rohloff Mattos (2003), nessa época também forja-se a idéia do Rio de Janeiro como a cabeça da monarquia, imagem associada à idéia de Brasil.

É a partir da concretude das formas e dos conteúdos que se manifestam no território que visamos compreender as ações e as idéias que se fazem sobre ele. Afinal, "em uma geografia do movimento, espera-se, em primeiro lugar, reconhecer o encontro de um tempo real e de um espaço real" (Santos, 2002a: 51).

Por isso a eleição de alguns objetos (a ponte, a porta, a janela...), como símbolos que transbordam sentidos a partir da forma. Esses objetos, materialidades de formas no espaço, ganham significado quando animados pelas ações sociais. Sem o movimento inerente à sociedades, o espaço - e seus objetos - é inerte, destituído de vida. Por isso a necessidade de desvendar formas e conteúdos em conjunto, a partir das realidades estudadas. Afinal, como dizia Milton Santos, "uma geografia social deve encarar, de modo uno, isto é, não-separado, objetos e ações ‘agindo’ em concerto”. (2002: 86) 
Acredita-se que o ato de relacionar geografia e história para o entendimento de realidades coloniais não só é possível, como necessário, para não cairmos na armadilha de transportar o estudo das formas fixas do presente para o exame do passado, sem perceber seu dinamismo. Remetendo-se a uma associação explicativa pautada por um movimento, que lida ora com o fluido, ora com o estático, ora com idéias e ações, ora com materialidades, esta reflexão conduz o pensamento à constante travessia da ponte entre a rigidez da conceituação e a fluidez da realidade sobre a qual se debruça. 


\section{A METRÓPOLE NOS TRÓPICOS: inversões no espaço}

\subsection{A soberania em trânsito}

A súbita transferência de toda a corte e seus pertences para a capital daquela que era a mais rica das colônias portuguesas foi um evento inusitado e sem precedentes. Trata-se de um momento singular na história, em que se invertem os papéis tradicionais, provocando um abalo na ordem das coisas. Afinal, conforme Ana Cristina Araújo (2005):

Nunca antes uma monarquia européia abdicara do seu território originário em prol de uma extensão periférica do seu império colonial. E, por mais importante que fosse a prosperidade econômica da parte em relação ao todo, nunca antes se vira uma colônia elevada à dignidade de reino.

Esta singularidade originou metáforas como a de "Versalhes Tropical", usada por Kirsten Schultz (2001), em livro bastante interessante que discute o período de permanência de D. João VI no Brasil. Quando pensamos em Versalhes, entretanto, estamos diante do tipo ideal da sociedade de corte, e "o produto mais visível desta interação entre a grandeza do reino e a grandeza da corte régia" (Elias, 1987: 20), no auge do Antigo Regime europeu. Podemos, a partir dessa experiência chave, pensar algumas semelhanças e diferenças com o Brasil joanino.

Ao deslocar-se o monarca para a periferia de seu vasto Império, toda uma dimensão simbólica muito forte é posta em risco. Afinal, segundo Norbert Elias: "o que se entende por 'corte' do antigo regime é, em primeiro lugar, a casa de habitação dos reis [...], de suas famílias, de todas as pessoas que, de perto ou de longe, dela fazem parte". Desse modo, "o rei domina o país por um processo que é a extensão da autoridade do príncipe sobre a sua casa e a sua corte" $(1987: 19,20)$. Por isso ser a autoridade real considerada como patrimonial, uma vez que ela se origina dessa autoridade pessoal.

O Rei do Antigo Regime era considerado a cabeça do corpo social, o qual se inspirava em seu comportamento, numa "concepção organicista do poder encarnado no corpo do rei, que, em si, resume toda a coletividade" (Souza, 1998: 23). Da mesma forma, o 
Império era visto como um corpo, o que se exemplifica no discurso de Antonio D’Oliva de Sousa Sequeira, que se refere ao Brasil como a cabeça do Império português ${ }^{5}$ :

[...] o tronco e cabeça formam a maior parte do corpo, e a essencia da vida; os membros extremos formão parte do todo, mas não são essenciaes para a existencia; ora sendo Portugal em relação ao Brasil, apenas um dos membros extremos, ou uma fracção, não padece duvida, que o grande corpo Portuguez ficaria informe com a cabeça fora do tronco, ou n'uma de suas fracções. Por outro lado, tambem não he menos inadmissivel, o dizer-se que o Brasil deve ceder á Mãi-Patria, e contentar-se com um Vice-Rei; na verdade, que a expressão tem euphonia, mas claramente manifesta um absurdo, porque he fóra de todo o encaixe, que o Reino seja sessenta vezes menor, que o Vice-Reinado. [grifos nossos]

É interessante ressaltar, para além da associação do espaço ao corpo humano, que D’Oliva localizava o Brasil como seu principal membro, sua cabeça, o que mostrava uma aceitação da hegemonia econômica e territorial da colônia sobre a metrópole.

$\mathrm{Na}$ acepção de Antonio Manuel Hespanha e Ângela Xavier, para a concepção organicista de poder, deveria existir um equilíbrio entre as partes do corpo, ou no caso, do Império, não sendo a centralização excessiva vista com bons olhos. Pensando sobre a administração e a partilha do poder, os autores afirmam que "tão monstruoso como um corpo que se reduzisse à cabeça, seria uma sociedade, em que todo o poder estivesse concentrado no soberano" (Hespanha \& Xavier, 1993: 123). Entretanto, fica latente no discurso de D’Oliva o entendimento de que, apesar de os "membros externos" formarem "parte do todo", eles não seriam essenciais para sua existência, visivelmente conferindo mais importância à "cabeça" do que ao resto do "corpo".

Contestando um tipo de interpretação que nega excessivamente a centralização, Rubem Barboza Filho (2000) realiza um longo percurso analítico que permite entrever de que maneira foi possível, em Portugal, a convivência de uma centralização em torno da figura do Rei com a possibilidade de brechas abertas pela infinidade de cargos

\footnotetext{
5 "Projecto para o estabelecimento político do Reino-Unido de Portugal, Brasil e Algarves, offerecido aos illustres legisladores em Cortes Geraes e Extraordinarias". Antonio D'Oliva Sousa Sequeira, 1821. IEBUSP.
} 
requeridos pela administração colonial ${ }^{6}$. Num mesmo sentido, as considerações de Laura de Mello e Souza (2006: 49, 50) visam a ponderar algumas contribuições da linha de pensamento que Hespanha vem consolidando: "O apreço ao esquema polissinodal e à microfísica do poder levam-no a enfraquecer excessivamente o papel do Estado e criar armadilhas para si próprio".

Era o próprio tipo de territorialidade vigente no Antigo Regime, fundado em princípios dinásticos, que garantia uma flexibilidade à centralização encabeçada pelo rei. Segundo Benno Teschke (2002), o território não era o ponto de partida de constituição da soberania, mas uma propriedade adjunta da dinastia vigente. Isso significa que a territorialidade dinástica se definia pela governança da Casa Real e não pela contigüidade territorial, inclusive admitindo, através dos diferentes domínios, a nãouniformidade administrativa: "a natureza personalista e imperfeita da soberania dinástica, assim como a lógica aditiva das aquisições territoriais impunha uma nãouniformidade administrativa" (Teschke, 2002: 24). Ou seja, apesar dos territórios pertencerem ao mesmo soberano, eles poderiam estar esparsamente localizados pelo globo, governados por leis que se adaptavam a cada contexto.

Mais que isso, uma vez que a soberania não estava fixada a um aparato estatal abstrato, ela poderia viajar com a Coroa $^{7}$, o que nos ajuda a compreender os diferentes projetos de mudança da Corte de Portugal para a América, muito antes das invasões napoleônicas, à medida em que se foi vislumbrando a crescente importância da América portuguesa para a sustentação de Portugal. Desde o século XVI podem-se localizar alguns germens desta idéia, que aparecia como uma alternativa às recorrentes ameaças que a Espanha representava ao trono português, sendo este tipo de alternativa defendida pelo jesuíta Antonio Vieira ${ }^{8}$.

\footnotetext{
6 "A rede administrativa, com seus postos e oportunidades [...] materializava para o rei uma espécie de território virtual a ser distribuído entre a alta nobreza, a hidalguía ascendente e a clerezia, com a nomeação de vice-reis, governadores, bispos, oficiais militares, capitães de navios, ouvidores, juizes, tesoureiros, contratadores e toda a procissão de personagens que povoaram a história da Ibéria e das Américas nestes séculos" (Barboza Filho, 2000: 273).

7 "Sovereignity was still not pegged to an abstract state apparatus, but travelled with the Crown" (Teschke, 2002: 23)

${ }^{8}$ Para uma explicação mais detalhada dos projetos de transferência da Corte para o Brasil ver Oliveira Lima (1996), Lyra (1994), Schultz (2006: 15-31).
} 
No século XVIII, o conselheiro Antonio Rodrigues da Costa se preocupava com a "balança" entre Portugal e Brasil, pois percebia o peso desta colônia em relação à Metrópole:

e bem se deixa ver que, posto em uma balança o Brasil, e na outra o Reino, há de pesar com grande excesso mais aquela que esta; e assim, a maior parte e a mais rica não sofrerá ser dominada pela menor, mais pobre; nem a este inconveniente se lhe poderá achar fácil remédio ${ }^{9}$

Um pouco depois, D. Luis da Cunha e o duque de Silva Taroca "enfatizaram, entre a década de 30 e 50 do século XVIII, a possibilidade de o Brasil se tornar cabeça do Império português" (Souza, 2007: 106) ${ }^{10}$. Percepção que também figurava entre as preocupações do Secretário Martinho de Mello e Castro, nas instruções dadas ao vicerei Luís de Vasconcelos e Sousa em 1779, em que dizia que: "sem Brasil, Portugal é uma insignificante potência; e que o Brasil sem forças, é um preciosíssimo tesouro abandonado a quem o quiser ocupar" ${ }^{\prime 1}$.

D. Rodrigo de Souza Coutinho considerava, em 1801, que Portugal já não era "a melhor parte da Monarquia" e que ainda restaria "ao seu soberano e aos seus povos o irem criar um poderoso império no Brasil, donde se volte a reconquistar o que se possa ter perdido na Europa” (apud Lyra, 1994, 110). No capítulo "O novo Império lusitano”, Maria de Lourdes Lyra (1994) discorre sobre a construção dessa idéia de criação de um grande e poderoso Império centrado no Brasil, utopia que foi tecida com ajuda dos discursos de ingleses, como o ministro William $\mathrm{Pitt}^{12}$, e que influenciaram ilustrados portugueses “anglófilos”, como o próprio Sousa Coutinho.

Para Rubem Barboza Filho (2000: 425), “o que d. Rodrigo de Souza Coutinho e outros anteviram foi a necessidade de sincronizar o centro político com o centro econômico do

\footnotetext{
9 "Consulta do Conselho Ultramarino a S.M., no anno de 1732, feita pelo conselheiro Antonio Rodrigues da Costa”, Revista IHGB, vol. 7. Apud Souza, 2007: 106.

10 “...considerei talvez visionariamente que Sua Majestade se achou em idade de ver florentíssimo e bem povoado aquele imenso continente do Brasil, se nele, tomando o título de imperador do Ocidente, quisesse estabelecer a sua corte, levando consigo todas as pessoas que de ambos os sexos o quisessem acompanhar, que não seriam poucas, com infinitos estrangeiros". D. Luis da Cunha. Instruções Políticas. (org. Abílio Diniz Silva). Lisboa, Comissão Nacional para as comemorações dos descobrimentos portugueses, 2001.

${ }_{11}^{11}$ Apud Bicalho (2006: 19).

12 "A diplomacia inglesa participou e pressionou, com firmeza, a mudança da sede do império português para o Brasil, chegando a reivindicar a autoria da idéia e, evidentemente, a co-participação nos frutos da instalação do império no Novo Mundo". (Lyra, 1994, 113)
} 
Império, situado no Brasil", percebendo a impossibilidade de dissociar a fonte de riquezas da fonte de poder. Além disso, também havia a questão da dimensão territorial do Brasil e as promessas de seus recursos, que seriam, por assim dizer, condição de sua potência e, ao mesmo tempo, possibilidade quase infinita de sua manutenção e ampliação. Tanto que para D’Oliva, escrevendo numa época em que a Corte já se encontrava no Rio de Janeiro, seria totalmente "fora de encaixe" que se revertesse o Brasil à condição de Vice-Reino, fazendo com que o Reino [Portugal] fosse "sessenta vezes menor do que o Vice-Reinado".

O fato é que seria mais fácil manter-se no plano das especulações ideais sobre o futuro da monarquia, se não tivesse ocorrido um evento que exigisse a tomada de medidas reais e urgentes, como foi a ofensiva napoleônica e o avanço das tropas de Junot sobre Portugal, em 1807, efetivando-se o tão comentado projeto de transferir a corte portuguesa para os trópicos ${ }^{13}$. Logicamente, a transferência não agradaria a todos, a começar pelos que divergiam da posição de d. Rodrigo, como o Conde da Barca, considerado "francófilo"14. Ainda, a decisão foi um duro golpe para boa parte da população lisboeta, que não tinha lugar reservado nas naus prestes a se lançar no Atlântico e se sentiu preterida. De acordo com Schultz (2000: 7), a mudança foi, "identificada pelos contemporâneos como um evento que desafiou as hierarquias políticas, culturais e econômicas consolidadas, contestou os modos tradicionais de representação e demandou a redefinição da legitimidade política no mundo português".

O Rei, ou, no caso, Príncipe Regente, era a figura que tinha um forte apelo paternal sobre seus súditos, o que transformava a "fuga" em um triste acontecimento, deixando toda uma nação de órfãos, como fica claro na memória do Visconde do Rio Secco:

O muito nobre, e sempre leal Povo de Lisboa, não podia familiarisar-se com a idéa da sahida d'El-Rey para os Dominios Ultramarinos. Encarava o futuro, e alem da

\footnotetext{
13 "Não havia já alternativa, em que escolher: ou se havia de abandonar ElRei, e Sua Real Familia á discrição do inimigo, para subir hum jugo, que não alliviaria a Nação [..] ou aproveitar a Esquadra para transportar estes preciosos restos da Gloria Portugueza para alguma de suas vastas possessões ultramarinas. Prevaleceu esta ultima resolução no Conselho: e, ou lhe desse pezo o perigo imminente, ou a brilhante perspectiva da riqueza do Brasil, ou a recordação do plano, que ao senhor D. José propozera o Marquez de Pombal, ou a idéa da união com a Inglaterra, para cooperar de concerto contra o inimigo, ou qualquer outra razão, que o Visconde do Rio Secco ignora..." "Exposição Analytica, e Justificativa da Conducta, e Vida Pública do Visconde do Rio Secco", 1821. Biblioteca Nacional do Rio de Janeiro (BNRJ), Obras Raras, 37, 17, 1

${ }^{14}$ Para uma leitura aprofundada das opiniões dos estadistas luso-brasileiros na época, ver Silva, 2006, especialmente capítulo 3 .
} 
orfandade, que descobria, ruminava no pensamento a serie de males, que ameaçavão os horizontes da sua cara Patria.

O fato ganhou tratamento diferenciado pela historiografia, sendo ora visto como fuga feita às $\operatorname{pressas}^{15}$ ou como uma "inteligente e feliz manobra" (Oliveira Lima, 1996: $43)^{16}$. Pode-se dizer que houve um pouco das duas dimensões, pois a "fuga", "transferência", ou "transladação", como quer que se chame, ainda que possa ser encarada como uma manobra política perspicaz, não era algo a ser celebrado. Tanto que podemos acreditar que:

A saída do príncipe regente foi discreta, e o embarque em si uma experiência pouco edificante para um soberano acostumado a profusas demonstrações de devoção. No porto não havia pálios de seda, cortinas adamascadas nem trilhas salpicadas de flores para o monarca de partida, mas apenas uma prancha de embarque rudimentar - duas tabuas de madeira deitadas sobre a lama - que levava de sua carruagem ao embarcadouro. (Wilcken, 2005: 39)

Para os habitantes do Brasil, a tristeza da notícia da fuga forçada foi sucedida por contentamento, como se nota em carta do governador da capitania de Pernambuco, Caetano Pinto de Miranda Montenegro:

Um coração patriótico, e que de tenros anos ama o seu soberano, ainda me não deixa enxugar as lágrimas que notícias tão tristes tem feito derramar aos bons portugueses. Mas logo que eu tenha a certeza da feliz chegada de Sua Alteza ao Rio de Janeiro, aos saltos e sobressaltos de um coração fiel hão de suceder tranquilas combinações da reflexão, as quais me pagarão tamanha mágoa e desgosto com um lucro tresdobrado de prazer e contentamento ${ }^{17}$.

\footnotetext{
${ }^{15} \mathrm{O}$ marinheiro inglês Thomas O'Neil, talvez com algum exagero, diz que, segundo relato de "um oficial a serviço de Sua Alteza Real": "milhares de homens, mulheres e crianças estavam constantemente na praia, empenhando-se por escapar a bordo. Muitas senhoras distintas entraram na água na esperança de alcançar os botes, mas algumas, desgraçadamente, morreram na tentativa; e, do dia 25 até o início do dia 28, não menos de dez mil pessoas estavam constantemente na praia, empenhadas em fugir" (2007: 57). É inclusive curioso que a recente publicação dos seus relatos, originalmente intitulada, de forma longuíssima, "A concise and accurate of the proceedings of the squadron under the command of the rear admiral Sir Sidney Smith, K. S. \& C. in effecting the escape of the Royal Family of Portugal..." (ou seja, a fuga da Família Real), teve como título "A vinda da família real portuguesa para o Brasil".

${ }^{16}$ Para uma revisão historiográfica do tema, ver Malerba (2000: 199-203) e Schwarcz (2002: 215).

${ }^{17}$ Carta enviada ao visconde de Anadia, João Rodrigues de Sá e Melo, por Caetano Pinto de Miranda Montenegro, governador da capitania de Pernambuco, em 1808. Arquivo Nacional, Fundo Ministério do Reino. Pernambuco. Correspondência do presidente da província. IJJ9 237.
} 
No Rio de Janeiro, o Senado da Câmara, assim que soube da novidade iniciou diversos preparativos, para demonstrar o seu "regozijo" e também para que o "espirito com q este Senado o recebeo" [ao Príncipe Regente] fosse digno de lembrança na "Historia Portuguesa, e na do Genero Humano". Para tanto, determinou, em 16 de janeiro de 1808, diversas providências a tomar, como preparar a Igreja do Carmo para um Tedeum, devendo irromper a orquestra no momento do desembarque; iluminar a cidade e seus arrabaldes por oito dias sucessivos (se encarregando o próprio Senado de oferecer cera para as casas próximas ao Palácio e à Praia de D. Manoel, onde iriam residir os criados de d. João); e incentivar "o povo a formar danças e dar outros testemunhos de sua alegria" ${ }^{18}$, entre outras determinações.

Na descrição realizada pelo Senado da Câmara, o momento da chegada foi de grande comoção para os habitantes, ansiosos por ver o Príncipe Regente e toda a sua família:

Hé incrivel o numero das pessôas de ambos os sexos que enchião a rua Direita, e a do Rosário no seo pavimento e nas casas, e hé muito mais incrivel q da bocca de quase todos sahião expressões sinceras de respeito, e dos olhos immensas lagrimas q confirmarão a sinceridade de seos corações ${ }^{19}$.

Conforme era de praxe nas coroações e eventos importantes da realeza (como aniversários), pintava-se um retrato do Monarca, acompanhado de emblemas de suas principais virtudes. Nas comemorações da chegada da família real, o príncipe regente foi homenageado da seguinte forma:

O author ornou este retrato com as conhecidas virtudes de S.A.R. de Religião, Justiça, Previdencia, Fortalesa e Magnanimidade e as pos em torno delle mesmo. A hum lado via-se a America absorta cahido o cocar de pennas, mas offerecendo a S.A.R. ouro, diamantes, e dando-lhe da boca estão letras = Mais que tudo o coração. A outro lado via-se a Asia e a Africa symbolisadas pelo Camello e pelo elephante offerecendo tambem a S.A.R. unindo os seos aos votos da America, dadivas, tributos, e sinceras provas da sua vassalagem. A serenidade das nuvens e do Céo q se vê e se descobre neste mesmo quadro symbolisa a felicidade que traz a America a vinda de S.A.R. a qual afugenta della tudo quanto causava mal... ${ }^{20}$

\footnotetext{
18 "Preparatórios no Rio de Janeiro para receber a Familia Real Portuguesa. Janeiro, 16, 1808”. BNRJ, Manuscritos, II - 35, 4, 1 .

${ }^{19}$ Idem.

${ }^{20}$ Idem
} 
Tratava-se de cunhar a imagem do grande Imperador, rodeado por três figuras: a América, a Ásia e a África. A Europa, talvez simbolizada pelo próprio Regente, não se fazia presente, pois representava, naqueles tempos conturbados, justamente a incerteza da continuidade dos preceitos básicos da monarquia. A América, em contraste, surgia, como contraponto a este cenário trágico, um oásis tropical sobre o qual se depositariam todas as esperanças de um futuro próspero ${ }^{21}$ :

Sua Alteza Real vai dar principio a um Santíssimo Império, que longe de receber leis iníquas, as dará sempre justas a muitas, muito ricas, e mui remotas regiões. O novo Império da América Meridional, separado pelo Oceano desse turbilhão cartesiano, ou desse incêndio, devorador de tantos tronos e monarquias, há de ser o asilo mais seguro da religião e da virtude; da justiça, humanidade e inocência oprimida; da indústria, comércio e de todas as artes, que voarão do antigo para este novo mundo, e nele abrirão canais imensos de riquezas incalculáveis ${ }^{22}$.

Para Luis Gonçalves dos Santos, o padre Perereca, era o início de "uma época de felicidade" (1981: 33), demonstrando o otimismo com que se tentou superar a crise vivenciada na Europa. Os exilados do Reino pouco a pouco foram percebendo que, ao contrário de infortunados, haviam tido sorte em terem a possibilidade de participar do projeto de construção de um "poderoso império" (Schultz, 2001) e depositavam suas esperanças no porvir. Já para os "leais vassalos" da América, a mudança trazia o aspecto positivo de representar o deslocamento de uma condição periférica para uma central. $\mathrm{Na}$ vivência cotidiana, entretanto, a construção deste ideal foi trabalhosa e exigiu uma série de ajustes e concessões, em diversas dimensões.

Conforme destaca Maurício de Abreu (1992: 61):

a festa e o jubilo que se seguiram à chegada dos ilustres visitantes [...] foram logo substituídos por inúmeros desafios, dentre os quais aquele de implantar rapidamente a burocracia estatal portuguesa na colônia, e a necessidade urgente de fazer a cidade, agora ampliada, assumir o novo papel que lhe fora reservado.

\footnotetext{
${ }^{21}$ Em um poema de um retrato comemorativo lia-se: "América felis tens em seu seio/ Do novo Império o Fundador Sublime/ Será este o País das Santas Virtudes/ Quando o resto do Mundo é todo crime". "Relação das festas que se fizeram no Rio de Janeiro, quando o Príncipe Regente N. S. e toda a sua real família chegaram pela primeira vez aquela capital". Apud Silva, 1978: 60.

${ }_{22}$ Carta enviada ao visconde de Anadia, João Rodrigues de Sá e Melo, por Caetano Pinto de Miranda Montenegro, governador da capitania de Pernambuco, em 1808. Op. Cit. [grifos nossos]
} 


\subsection{Abrindo as janelas: a cidade em transformação}

Diversos estudiosos calculam entre 10 mil e 15 mil o número de pessoas que chegaram ao Rio com a Corte em $1808^{23}$. Segundo Santiago de Andrade (2007), a comitiva real trouxe consigo, só de criados, cerca de trezentas pessoas ${ }^{24}$ (número que chegou a aumentar $60 \%$ depois de instalada a família real na cidade). A necessidade de abrigar a todos estes novos habitantes fez com que diversos moradores fossem desalojados, a partir do mecanismo da "aposentadoria", que visava garantir habitação aos nobres recém-chegados. De acordo com o comerciante inglês John Luccock (1975: 68), "uma das primeiras ordens baixadas após a chegada do príncipe dispôs que ninguém poderia ter simultaneamente duas casas, e alguns dos que gozavam de pouca influência na Corte viram-se em dificuldades para conservar mesmo uma".

Tal mecanismo gerou polêmica, pois os nobres costumavam requisitar casas de comerciantes, cujo negócio se localizava no mesmo edifício, como alvo de sua pretensão de moradia. Em resposta, os negociantes se organizaram e protestaram contra o fato de "pessoas de fora" pedirem como aposentadoria as suas próprias casas de negócio ${ }^{25}$. Além disso, houve uma recusa generalizada em construir novas casas, por medo de que elas fossem tomadas (Carvalho, 2003).

\footnotetext{
${ }^{23}$ Nireu Cavalcanti (2004), refaz os cálculos, a partir das listas de passageiros de cada embarcação que aportou no porto fluminense, trazendo membros da Corte, e chega na cifra bem menos numerosa, de 444 pessoas, mas que parece ser demasiado reduzida. Carlos Eduardo Barata (2008) parece pôr fím à polêmica, em estudo minucioso que afirma que no mínimo 11.528 pessoas atravessaram o Atlântico na aventura da transmigração da Corte portuguesa para os trópicos, mas que apenas cerca de $10 \%$ desembarcaria no Rio de Janeiro, uma vez que a grande maioria da tripulação era composta por membros da Marinha de Guerra.

${ }^{24}$ Relação das pessoas que saíram desta cidade para o Brasil, em companhia de Sua Alteza Real, no dia 29 de novembro de 1807. Lisboa. IHBG, lata 490, pasta 29; ANRJ, fundo Negócios de Portugal, cód. 730. Apud Andrade, 2007.

25 "experimentão porem, que vindo pessoas de fora, e inda da terra, pedem de appozentadoria as casas de negocio, em que os Sup. Residem, o q he prejudicialissimo ao Comercio, pois estes citios devem ser illivados, e izentos, de Apposentadorias de outros, que não sejao Comerciantes, residentes nas mesmas, a exemplo de Lisboa, q se achava regulada a respeito dos indeviduos habitantes, conforme as classes de cada hum delles, e dos traficos, e occupações de seos misteres: por estes principios implorão os Sup. De V. A. R, para que haja por bem privilegiallos com appozentadoria, nos lugares destas rezidencias em q existem empregados no Comercio, regulando-se a sua estabelidade pelas cituacções já antigas, e proprias para sua conservaçao". Rio de Janeiro - comerciantes. Requerimento de aposentadoria das casas de negocio onde residem, 1808, BNRJ, Manuscritos, II 30, 24, 27.
} 
Por outro lado, diversos membros da elite local se prestaram, de legítima vontade, ao empréstimo de moradias aos fidalgos da Corte, tentando garantir boa impressão ao rei. Boa parte destes proprietários eram negociantes que visavam entrar no núcleo de poder e diligência, através de uma política de cooperação (Gorestein, 1993: 221). Alguns deles chegaram a alugar casas maiores para chamarem a atenção da corte e cedê-las para moradia dos reinóis, assim como emprestavam "espontaneamente seu dinheiro, suas casas e quase que todas as suas comodidades" (Luccock, 1975: 68).

Este foi o caso de Elias Antonio Lopes, que doou à família real sua casa de campo, localizada em São Cristóvão. O Paço de São Cristóvão, ou a Quinta da Boa Vista, como também era chamado, ficava nas cercanias da cidade. Segundo Luccock, o "quintal" da Boa Vista era "acanhado e pretensioso, mal construído e pessimamente mobiliado". O viajante, todavia, afirmava também que o palácio dispunha "de um grande conforto, pois que de três lados possu[ía] 'varandas' ou colunatas, com janelas envidraçadas, que tanto podem ser fechadas, como manter-se abertas; e assim, consegue-se calor, luz e arejamento" (1975: 176).

A habitação principal da família real, o antigo palácio do Vice-Rei, no Largo do Paço, era descrita por Luccock como "miserável para um rei, embora dignificada com o nome de palácio. É verdade que possuíam, além disso, o correr de edifícios do outro lado da praça, de que já se falou; mas, mesmo assim, as acomodações deviam estar muitíssimo aquém das necessidades" (1975: 65). Os outros edifícios a que se refere Luccock eram as dependências do Convento do Carmo e do Senado da Câmara (onde também se localizava a Cadeia Pública) que foram anexadas ao Palácio por um passadiço, como forma de ampliar sua magnitude.

Segundo Jean Debret, “o Príncipe regente D. João VI [...] habitava a contragosto o palacete do vice-rei, situado quase no centro da cidade e que fora antes a Casa da Moeda; por isso, logo se apressaram em satisfazer seus desejos oferecendo-lhe a chácara de São Cristóvão, a três quartos de légua da capital, para que fizesse dela sua residência habitual" (1978: 139). Já Thomas O’Neil parece ter se impressionado com o Palacete, talvez por sua imaginação lhe haver prometido uma cidade muito mais rústica do que a que encontrou (2007: 73): 
Os habitantes de Santa Sebastian [São Sebastião] receberam de braços abertos os ilustres fugitivos; tudo que o zelo e a lealdade os impeliram a fazer foi feito; e a Família Real fixou residência no palácio usualmente ocupado pelo vice-rei, um edifício que, por sua suntuosidade, ultrapassa o que um europeu poderia imaginar, quando se considera que, aos diversos vice-reis, era quase inteiramente impossível um intercâmbio com qualquer outra nação.

Em alvará de 10 de maio de 1808, d. João VI criou a Intendência Geral da Polícia da Corte e Estado do Brasil, nomeando Paulo Fernandes Viana como Intendente, para zelar pela ordem na cidade e na sua comunicação com o resto do território. A Intendência da Polícia se configura como uma instituição espacializada, cuja jurisdição era o território do Estado do Brasil e cuja função seria justamente zelar pela "ordem" e pela "coerência" deste espaço e de sua população ${ }^{26}$. Desse modo, além do embelezamento da cidade e do policiamento de seus habitantes, buscava-se prover as regiões desconectadas de estradas e povoar os seus sertões.

No que diz respeito à cidade do Rio de Janeiro, pela necessidade de se fazê-la uma cidade de corte, fazia-se urgente eliminar alguns "traços" coloniais, não condizentes à morada do monarca, assim como adaptar construções antigas a novos usos e, ainda, criar novas estruturas urbanas.

Utilizando dois percursos reflexivos distintos, porém convergentes, podemos avançar um pouco sobre a questão. Para Bernard Lepetit, historiador-geógrafo francês, a cidade, enquanto categoria em movimento, é inscrita na perenidade, mas a partir de diferentes fragmentos, que por vezes ocasionam um descompasso entre as formas e os conteúdos de seus usos. Assim, “organizados inicialmente para caminhar juntos [...], um espaço e seu uso, desarmonizam-se: toda a história das muralhas que cercam as cidades poderia ser escrita, na época moderna, desse ponto de vista, por exemplo" (Lepetit, 1996: 80). A partir dessa constatação, o autor empresta de uma obra sociológica ${ }^{27}$ a idéia de "traço", para denominar todos os pedaços descombinados de que as cidades são feitas. Segundo ele, "o traço começa com a desadaptação, com o fim das possibilidades de ajuste" e seu

\footnotetext{
${ }^{26}$ Para Michel Foucault (2002: 197): “o que se chamará até o fim do Antigo Regime de polícia não é somente a instituição policial; é o conjunto dos mecanismos pelos quais são assegurados a ordem, o crescimento canalizado das riquezas e as condições de manutenção da saúde 'em geral"'.

${ }^{27}$ D. Colson, J. Nizey, J. Roux. Um quartier industriel à Saint-Etienne. Le Marais entre histoire et planification, Lyon, 1993
} 
destino pode ser variado; por exemplo, "pode-se tomar uma decisão de apagar do presente os objetos indexados no passado", ou mesmo transformá-los para um novo uso. Neste último caso, se há uma reativação do uso, as formas descompassadas:

escapam à sua condição de traço para serem reinseridas, numa nova coincidência entre uma forma, um uso e seu valor, no circuito do sentido social. Essa reativação não retoma senão uma parte das dimensões do objeto: uma localização, uma forma, um valor simbólico, um valor econômico... para fazê-lo atuar de outro modo, e com outros fins. Mas ela permite que a cidade, cujos elementos provêm quase todos de passados com profundidade diferente, seja sempre inteiramente contemporânea a si mesma. (Lepetit, 1996: 82)

Impossível não nos remetermos às rugosidades de Milton Santos, conceituação trabalhada em mais de uma de suas obras, na busca por entender este descompasso de que nos fala Lepetit. Enquanto o traço, no raciocínio do historiador francês, é mais fugaz, deixando de sê-lo à medida em que é reinserido no uso social, a rugosidade "miltoniana" é justamente uma permanência pretérita na paisagem presente, podendo ser adaptada a um novo uso: "chamemos rugosidade ao que fica do passado como forma, espaço construído, paisagem. [...] Em cada lugar, pois, o tempo atual se defronta com o tempo passado, cristalizado em formas..." (Santos, 2002a: 140).

Temos um caso típico de traço arquitetônico a ser eliminado com a chegada da Corte no Rio de Janeiro: as rótulas, treliças de madeira alojadas nas janelas, que permitiam a entrada de ar sem devassar a privacidade do espaço interno das moradias. Em medida de 11/06/1809, Paulo Fernandes Viana, o Intendente Geral da Polícia, suprimia o uso da rótula, com a seguinte justificativa:

[A cidade do Rio de Janeiro, possuindo] a alta jerarquia de ser hoje a Corte do Brasil, que goza a honra, e da ventura de ter em si o seu legítimo soberano e toda a sua real Família, não pode, nem deve continuar a conservar bizonhos, e antigos costumes, que apenas podião tolerar-se, quando era reputada como huma Colônia, e que desde muito tempo não sofrem as povoações cultas, e de perfeita civilização. ${ }^{28}$

Para Viana, as rótulas, sendo uma influência oriental (e não européia, ou mais especificamente, inglesa ou francesa, como seria desejável) "afe[iavam] o prospecto da

\footnotetext{
${ }^{28}$ Arquivo Nacional do Rio de Janeiro (doravante ANRJ), Polícia da Corte, códice 323, vol.1, fls.88-89, 11/06/1809. Apud Marins, 1999 [grifo nosso]
} 
Cidade" e denotavam "falta de civilização". Eram, ainda, "testemunhos da Antiga condição de colônia" ${ }^{29}$, afirmação que deixa transparecer a intenção de Viana em eliminar os traços que lembrassem que a Corte estava instalada em uma antiga capital colonial. Tratava-se de efetuar a transformação da cidade colonial em cidade cortesã, começando pelas mudanças espaciais. Afinal o espaço é, ele próprio, "um testemunho; ele testemunha um momento de um modo de produção pela memória [...] das coisas fixadas na paisagem criada" (Santos, 2002b, 173).

A questão das rótulas pode parecer pequena à primeira vista, mas abre portas para importantes questionamentos, conforme bem notou e trabalhou Paulo Garcez Marins (1999). Herdada da arquitetura muçulmana, a rótula permitia "ver sem ser visto", possibilitando "a comunicação e a sociabilidade, sem que os espaços associados à condição senhorial fossem formalmente transpostos". (1999: 33). Para Gilberto Freyre (2000: 235), até então, "o sobrado de rua, de tanto se defender do excesso de sol, do perigo dos ladrões e das correntes de ar, [era] uma habitação úmida, fechada. Quase uma prisão".

Nestas "prisões" se escondiam um dos tesouros mais resguardados da cidade colonial: as mulheres, que mal saíam de casa e visualizavam a rua enxadrezada pelas treliças. $\mathrm{O}$ isolamento da mulher no Rio de Janeiro, hábito influenciado pela cultura moura, foi comentado por diversos viajantes estrangeiros no início do século XIX, cujos olhos estavam acostumados à maior exibição do sexo feminino. Segundo Marins, "a idéia da visibilidade das mulheres passou a ser um dos critérios burgueses para julgar o progresso ou o atraso dos costumes nos diferentes aglomerados urbanos europeus" (1999: 12). Na América portuguesa, tamanho era o zelo com as moças e senhoras de família que às ditas "mulheres públicas" se dava a alcunha de "mulheres de janela", associando-se a mínima exposição da vida privada com prostituição ${ }^{30}$.

Assim, pode-se dizer que a condição de colônia estava estampada na janela das casas. E estas, até então, se encontravam fechadas, não por algo estanque, mas por uma estrutura porosa, que permitia a passagem de ar e luz, ao mesmo tempo em que garantia uma

\footnotetext{
${ }^{29}$ Idem, grifo nosso.

30 "O médico Pires de Almeida calcula que, ao findar o século XVIII, houvesse no Rio de Janeiro cerca de 255 das chamadas 'mulheres de janela', isto é, 'mulheres públicas'” (Freyre, 2000: 189).
} 
certa sombra necessária à manutenção da ordem patriarcal. Para Georg Simmel, em ensaio originalmente intitulado "Brücke und Tür" (Ponte e porta), a janela evoca um sentimento teleológico que vai do interior ao exterior, num caminho que só cabe ao olho percorrer $^{31}$. Ou seja, a janela representa uma abertura para o mundo exterior realizada pelo olhar, e que se dá de forma unilateral. Com relação às rótulas, essa função se exacerbava, uma vez que as treliças protegiam o interior das casas de olhares estranhos.

Freyre (2000) enquadra esta passagem, em que se abrem as janelas dos sobrados, dentro de um processo de "reeuropeização" dos costumes, motivado pela chegada da corte joanina, que visava a eliminar os traços orientais e africanos, tão marcantes até então, da paisagem das cidades coloniais da América portuguesa. Trata-se de um momento de construção de uma urbanidade, que requeria novas articulações entre o espaço público e o privado ${ }^{32}$. Eliminar as treliças para que os olhos alheios pudessem se prolongar pelas salas recônditas, confrontando as sombras da casa com a luz da rua. Seria este um processo de: "desassombramento através do vidro inglês nas casas e nas carruagens ainda orientalmente revestidas de gelosias e cortinas: as casas de 'grades de xadrez' que a Walsh recordaram as dos Turcos" (Freyre, 2000 - grifo nosso).

O uso do vidro inglês espelhava os novos costumes "civilizados" - trazendo a transparência necessária à nova sociabilidade urbana que se moldava -, mas ao mesmo tempo refletia uma necessidade comercial: havia estoques encalhados do produto no porto do Rio de Janeiro e a medida de remoção das rótulas impulsionou o incremento das vendas (Marins, 1999; Freyre, 2000). Mais do que nunca, buscava-se agora a aprovação dos olhos estrangeiros, com a forte presença inglesa ditando as novas modas

\footnotetext{
31 "Le sentiment téléologique, lorsqu'il s'agit de la fenêtre, va presque uniquement de l'interieur à l'exterieur : elle sert à voir dehors et non dedans. Sans doute établit-elle, par la vertu de sa transparence, la liason entre l'interieur et l'exterieur pour ainsi dire chroniquement et continûment; mais la direction unilaterale qu'elle imprime à cette liason, et la restriction que la limite à n'être un chemin que pour l'oeil, confèrent à la fenêtre une partie seulement de la signification profonde et principielle de la porte ». (Simmel, 1998: 165)

${ }^{32}$ É interessante como a janela também era uma metáfora para a posse de cidadania (termo igualmente atrelado à vida pública), conforme fica patente no caso de negros livres em Sergipe, que, quando alforriados e deslocados para mucambos, diziam: "Vou tê agora jinela e porta de fundo", em oposição à "senzala típica que não tinha nem janela de frente nem porta de fundo, sendo, como era, prisão, ou 'pombal', como a denominou Joaquim Nabuco". (frase colhida pelo pesquisador sergipano Felte Bezerra, em Etnias sergipanas. Contribuição ao seu estudo. Aracaju, 1950). Do mesmo modo, a construção de balcões e alpendres à frente ou ao lado dos mucambos, onde os negros ou pardos livres ostentavam seu ócio, denotava a importância da exibição pública da condição de homem livre. Freyre, 2000: 160, 161.
} 
(juntamente com a francesa, intensificada após 1816, baixada a poeira do furacão napoleônico).

E os 'olhos dos Estrangeiros' eram os olhos da Europa. Eram os olhos do Ocidente. Do Ocidente burguês, industrial, carbonífero, com cujos estilos de cultura, modos de vida, composições de paisagem, chocavam-se com as nossas, particularmente impregnadas de sobrevivências do Oriente. (Freyre, 2000: 457).

A visibilidade ${ }^{33}$ buscada pela remoção dos bisonhos costumes do uso das rótulas foi acompanhada por um empenho na iluminação pública, que era considerada "grande auxiliar do policiamento" (Araújo, 1898: 38). Lampiões de azeite tornavam mais seguros os percursos noturnos por pontos importantes da cidade, como o Paço Real, a Quinta da Boa Vista, a praça e a casa das Laranjeiras.

Para Luccock (1975: 26), as rótulas davam um ar pesado à cidade, mas sua remoção repentina foi algo estranha, pois a substituição por vidro tornou as casas subitamente devassadas. Aos moradores restava se resignar e imitar a moda, ainda que este traço colonial seguisse fixado na paisagem do Rio de Janeiro todo o século XIX. Por muito tempo a rótula permaneceu presente na vida da cidade, principalmente nas casas menos abastadas e nas casas térreas, isentas na medida. Escrevendo em fins da década de 1810, os viajantes prussianos von Leithold e von Rango, afirmavam que "a maioria das casas é de um só pavimento e apenas uma janela, que, em muitas, é inteiramente de madeira, isto é, fechada por uma grade de trama apertada como a de nossos galinheiros ou pombais" (1966: 11).

Se mesmo uma estrutura acessória, como era a rótula, feita de madeira e facilmente suprimível, conseguiu sobreviver ao desaparecimento, o que não dizer de outros "traços desconjuntados na paisagem", ou outras rugosidades, de composição física mais durável, como era o caso dos edifícios. Quanto maior o investimento de mão-de-obra, tempo e material, ou mesmo quanto maior a carga simbólica materializada em determinada construção, mais difícil suprimir as antigas formas.

\footnotetext{
33 "Se os olhos dos cariocas viam o rei através das rótulas, que fosse dada à sua majestade o direito de ver seus leais súditos com facilidade. A alta hierarquia a que se tinha alçado o Rio de Janeiro diante do império ultramarino, da antiga Metrópole e das nações estrangeiras, deveria ser constituída interna e socialmente na própria sede da Corte, encimada pela régia e pátria figura, que a todos os seus filhos deveria ver..." (Marins, 1999: 169).
} 
No caso do Palácio Real, a dificuldade material de providenciar uma construção de proporções majestosas em tão pouco tempo levou à adaptação da moradia do Vice-Rei, de proporções não tão nobres, para serventia da família real. Não escapou aos relatos de viajantes estrangeiros este descompasso existente entre o grande Império sob domínio do Príncipe Regente e a sua humilde morada. Conforme relato de Spix e Martius, a aparência do palacete do largo do Paço, apesar "de todo construído segundo o estilo dos palácios europeus; [...] não condiz[ia] com a grandeza do monarca de um reino tão promissor e florescente”. (1981, vol. 1: 48, grifo nosso). Fazia-se urgente, então, a construção de uma aparência de realeza para o palácio da família real, assim como para suas aparições publicas e celebrações ${ }^{34}$.

${ }^{34}$ Para Andrade (2007: 121): "dois princípios norteavam a ação da elite dirigente da Casa Real portuguesa enquanto esteve no Brasil: reproduzir, no espaço historicamente colonial, o processo de expansão e manutenção de uma extensa rede de dependentes do universo doméstico joanino, algo que já vinha sendo praticado desde pelo menos o começo do século XVIII em Portugal e preservar uma imagem e memória que vinculassem a Casa a uma idéia de opulência e poder na nova Corte que se estabeleceu no Rio de Janeiro". 
Figura 1. O Palácio Real

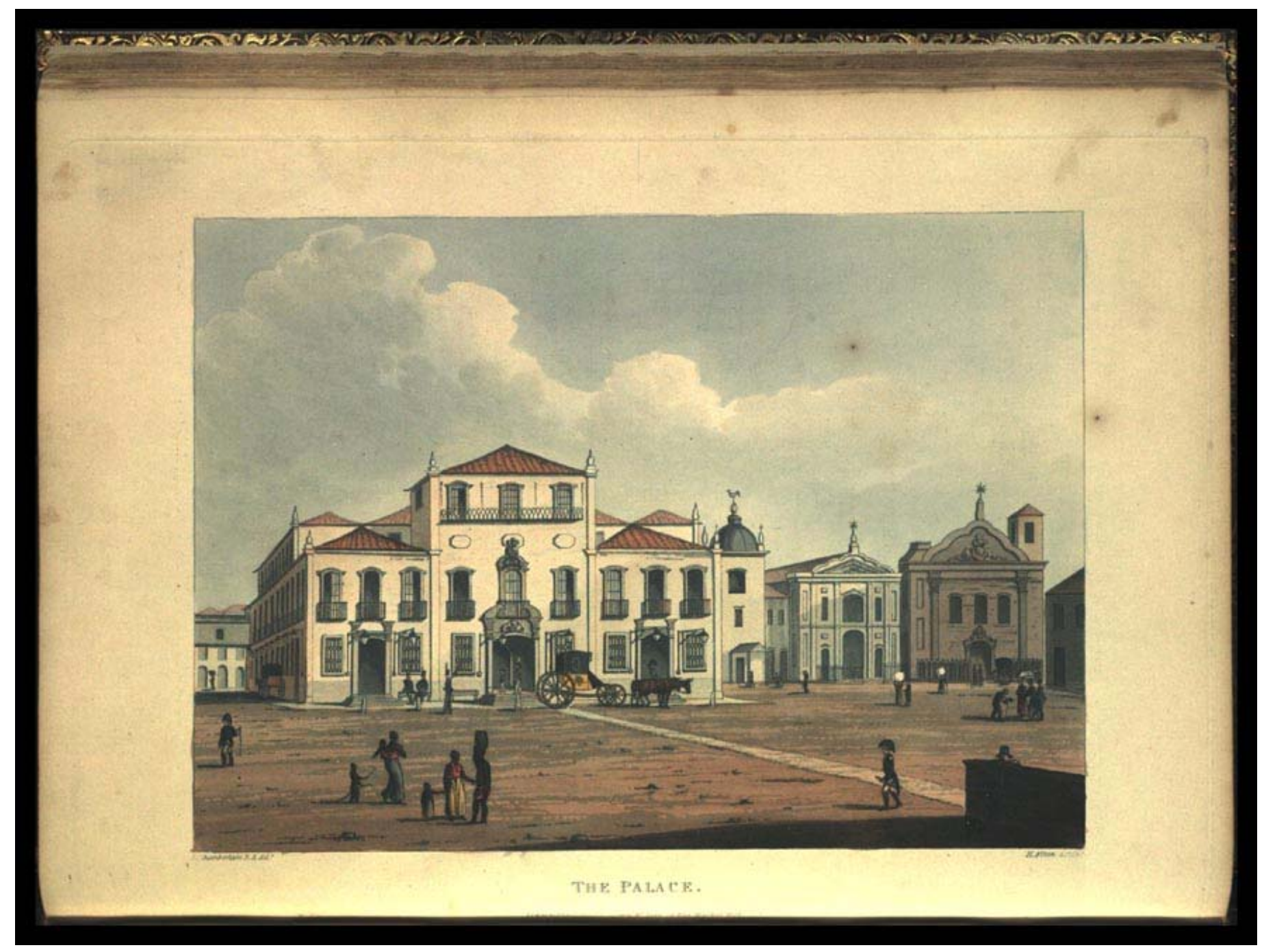

Vista do Palácio Real, retrado por Henry Alken, em 1822 (Londres, Howlett and Brimmer) Biblioteca Nacional do Rio de Janeiro (catálogo digital) 
Norbert Elias, remetendo-se à sociedade de corte de Luis XIV, constata que a aparência era fundamental na sustentação da legitimidade do regime (1987: 31):

Um alto nível social obriga o seu detentor a ter um palácio e a garantir a sua boa aparência. Aquilo que na óptica de uma moral burguesa não passa de desperdício ('se tem que contrair dívidas, porque não reduz o seu estilo de vida?") é, na realidade, a expressão de um ethos próprio da ordem dos senhores. Este ethos emana das próprias estruturas e da actividade da sociedade cortês. Por outro lado, ele assegura o seu funcionamento.

Especificamente sobre a monarquia portuguesa, Moses Pechman afirma que:

Nessa sociedade, onde o ver é privilegiado em detrimento do contato físico, se desenvolve intensamente um ritual que, do corpo do rei, se transmite a todos a partir das aparências e que se expressa nas vestimentas, nos gestos, na fisionomia, enfim, em tudo o que diz respeito ao comportamento em público ${ }^{35}$. (Pechman, 2002: 70).

Em oposição à luminosidade trazida aos locais nobres da cidade, contrastava a cadeia, nos arredores da cidade, aos pés do morro da Conceição: “úmida, insalubre, inabitável, sobretudo do lado da montanha". (Araújo, 2007). Elysio Araújo, escrevendo num contexto republicano e portanto um tanto ressentido com a monarquia, destaca que a ocupação do Palácio do vice-rei fez remover a cadeia para a prisão eclesiástica do Aljube, em prédio "acanhado, infecto, sem ar e sem luz, onde, amontoados os presos, em revoltante mistura de idades, sem attenção aos crimes que haviam commettido, jouveram durante longo tempo" (1898: 37).

Despachar para longe dos olhos as atividades mais degradantes e incômodas, mas ao mesmo tempo necessárias ao funcionamento da sociedade colonial, parecia ser o imperativo, já desde fins do século XVIII. A iniciativa do Marques de Lavradio (vicerei de 1769 a 1779) de transferir o mercado de escravos africanos da rua Direita e becos análogos para a Praia do Valongo, mais longínqua, livrando o centro da cidade do "espetáculo mais horroroso que podia se apresentar aos olhos"36, prescindiu este movimento. Na mesma chave, se compreende sugestões dadas por Manuel Vieira da Silva (1808) em seu Reflexoes sobre alguns dos meios propostos por mais conducentes

\footnotetext{
${ }^{35}$ As aparências do corpo e "de tudo que diz respeito ao comportamento em público" eram também as aparências do espaço construído que girava em torno do monarca.

${ }^{36}$ Relatório do Marquês de Lavradio, Apud Bicalho, 1997: 434.
} 
para melhorar o clima da cidade do Rio de Janeiro, em que discursa sobre a necessidade de distanciar os matadouros e cemitérios das áreas centrais, assim como de fiscalizar essas atividades ${ }^{37}$.

Vieira da Silva argumenta que "os enterros dentro das Igrejas tem merecido a reprovação de todas as sociedades illuminadas, e particularmente a merecem nesta Cidade em razão do calor athmosférico, e da pouca largura das ruas". Assim, além de sugerir o estabelecimento de cemitérios "nas extremidades da Cidade" (lembrando que era necessário, na sua instalação, "conservar as diferenças sociais"), o médico também considerava prudente que houvesse um controle do Estado sobre os corpos falecidos, a fim de evitar envenenamentos e assassinatos, uma vez que, até então, bastava, "para enterrar hum defunto, o introduzillo n'huma rede, e pagar a dous pretos, que o conduzão". (Silva, 1808: 17)

Ao mesmo tempo em que estas atividades se transferiam para longe do centro, também houve um movimento de ocupação dos belos arredores da cidade por membros da nobreza. Seguindo os passos da família real, a aristocracia resolveu se instalar pelos novos subúrbios do Rio, para construir também os seus palacetes. E “os negociantes procuraram morar nos mesmos bairros que a nobreza" (Gorestein, 1993: 190). Segundo Maria Beatriz Nizza da Silva (1978: 40-42), estrangeiros, aristocratas e altos funcionários procuravam evitar a cidade, morando em locais mais distantes, entre os quais Botafogo era um dos preferidos, pelas belezas naturais e por ser o sítio escolhido por D. Carlota para fixar residência. No Catete, próximo a Botafogo, moravam Silvestre Pinheiro Ferreira, alto funcionário, e também o negociante Fernando Carneiro Leão, além de estrangeiros e ministros diplomáticos.

Outros lugares elegantes eram a estrada de São Cristóvão, em direção à Quinta da Boa Vista, Laranjeiras e Engenho Velho, onde morava o Intendente da Polícia, Paulo

\footnotetext{
${ }^{37}$ Michel Foucault (2002: 201), refletindo sobre a cidade enquanto "objeto a medicalizar", afirma que a partir do século XVIII ganha notoriedade o discurso médico sobre a morbidade urbana e a necessidade de vigilância. Nesta chave, "a localização dos diferentes bairros, sua umidade, sua exposição, o arejamento total da cidade, seus sistemas de esgotos e de evacuação de águas utilizadas, a localização dos cemitérios e dos matadouros, a densidade da população constituem fatores que desempenham um papel decisivo na mortalidade e morbidade dos habitantes". Foucault considera os médicos da época verdadeiros "especialistas do espaço": "Eles foram, juntamente com os militares, os primeiros administradores do espaço coletivo" (2002: 214).
} 
Fernandes Viana (Gorestein, 1993; Silva, 1978). O estabelecimento da família real no arraial de São Cristóvão propiciou a valorização da terra urbana e a mudança de setores da elite para a região, após o aterramento do Saco de São Diogo que dificultava o acesso ao local (Abreu, 1987). "Habitar longe do centro, no Catete, em Botafogo, na Ponta do Caju, significava possuir um meio de transporte próprio" (Silva, 1978: 54). Ou seja, era também uma questão de prestígio morar nos subúrbios, pela distinção social que a posse de sege ou carruagem para locomoção acarretava.

Comerciantes, artesãos e alguns empregados públicos se localizavam mais na região central da cidade. As freguesias da Candelária e de São José, que passam a abrigar o Paço Real e as repartições mais importantes do Reino, também se constituíram em local de residência almejado pelas classes dirigentes. No centro, as ruas principais eram: a Rua Direita e Rua dos Pescadores, que reunia os negociantes de atacado; a Rua da Vala, Rua São José, Rua da Cadeia, Rua do Ouvidor, Rua detrás do Hospício, travessa da Alfândega, Rua do Sabão, Rua de S. Pedro e Rua das Violas, onde se localizavam os artesãos; e a Rua do Rosário, ocupada por taberneiros, quase todos ilhéus (Silva, 1978). O comerciante inglês John Luccock fixou sua primeira residência no Rio na Rua do Ouvidor com a Rua da Quitanda, de onde podia observar os advogados e meirinhos, que se encontravam para tratar de negócios (Luccock, 1975: 70).

Em 1809, algumas obras foram feitas para aprimorar a circulação urbana, como o calçamento das principais artérias (Ouvidor, São José e Cadeia), o revestimento de granito do largo de São Francisco, e a abertura de um caminho do cortejo real, ligando São Cristóvão ao largo do Paço (Los Rios Filho: 2000). As obras eram constantes, para dar conta do crescimento populacional e da ocupação das cercanias da cidade.

Por sua vez, a margem norte, para os lados do Saco do Alferes, Catumbi e Mataporcos abrigava as pessoas mais miseráveis. (Silva, 1993: 213). Já os quilombos se localizavam nas áreas mais afastadas e protegidas, principalmente na Tijuca, no Corcovado e no morro de Santa Teresa (Karasch, 2000). 
Figura 2. Vista da Montanha do Corcovado e do subúrbio do Catete

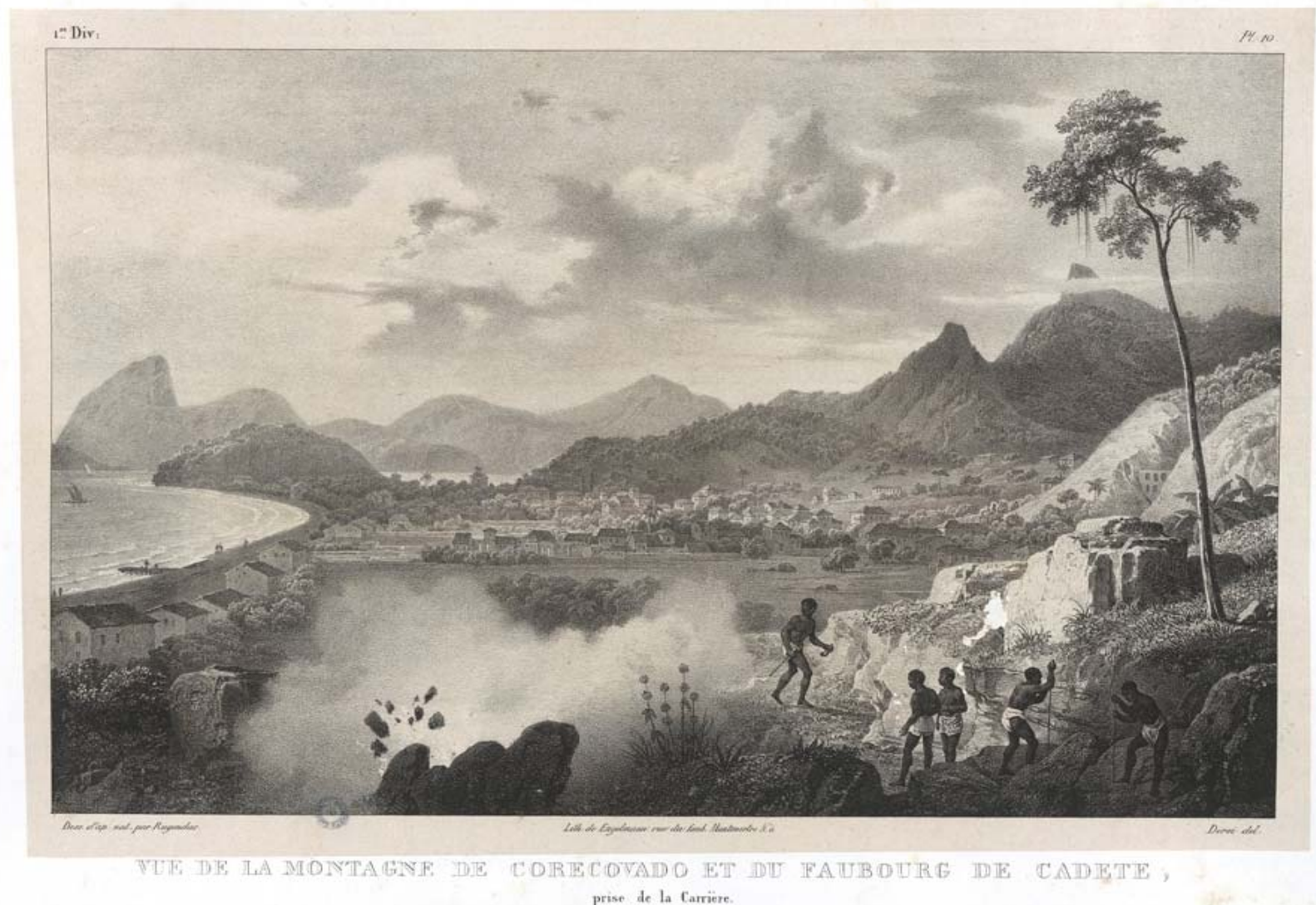

Johann Moritz Rugendas. Viagem Pitoresca através do Brasil. Lith. de G. Engelmann, 1835

Biblioteca Nacional do Rio de Janeiro (catálogo digital)

“Aos pés do Corcovado, trabalhadores usavam explosivos parra arrancar granito da face da rocha. Havia outras pedreiras na Glória e no Catete, a vinte minutos de caminhada do centro, onde as encostas dos morros eram reduzidas a pedregulhos, carregados para canteiros de obras por toda a cidade. Noutros locais, erguiam-se pequenos outeiros". (Wilcken, 2005: 197) 
Uma importante medida realizada por D. João VI, que teve impacto na cidade, foi a criação, em 07 de junho de 1808, da Décima Urbana, imposto predial que equivalia a $10 \%$ do rendimento dos prédios urbanos. O impacto de tal medida foi enorme, pois até então somente pagavam impostos aqueles que habitassem terrenos pertencentes à Câmara, através do foro. O ônus que a medida representou para a população foi repassado para os inquilinos, provocando um aumento nos aluguéis. Tal medida também ensejou a necessidade de se demarcarem os limites da cidade e das propriedades, para definição da área de abrangência do tributo. Em 15 de outubro de 1808 o senado da Câmara foi obrigado a estabelecer os limites da área urbana do Rio de Janeiro, a qual acabou sendo aumentada (Moraes, 1872).

A subida nos aluguéis acabou por restringir as populações mais pobres aos bairros mais distantes $^{38}$. Aqueles sem poder de mobilidade, na impossibilidade de avançarem pelo mangue de São Diogo, se concentravam em Santana e Santa Rita, freguesias urbanas ao norte (Abreu, 1987). Este mangue representava o limite da sesmaria dos jesuítas no século XVIII, o que havia ocasionado muitas querelas quanto à sua ocupação eventual por lenhadores, donos de curtumes, produtores de cal extraído da casca de mariscos, carvoeiros, exportadores de varas para os vinhedos de Portugal, fornecedores de madeira para construção e catadores de caranguejos. Os jesuítas se opunham a essas pessoas, pela defesa de sua sesmaria, acirrando a antipatia da população local pelos inacianos. Após a decisão de expulsão destes pelo Marquês de Pombal, as atividades mencionadas se intensificaram (Cavalcanti, 2004: 72).

Para Manuel Vieira da Silva, o aterramento de mangues e áreas pantanosas também representava atitude sadia para "melhorar o clima" da cidade, assim como o encanamento das águas e o ordenamento das edificações:

He por consequencia da boa policia o aterrar todos os lugares pantanosos, o encanar as aguas para aquellas vallas, que se julgarem suficientes ao seu despejo, e que devem participar das alternativas da maré; o determinar o lugar, em que se devem edificar as cazas, a altura da porta à estrada, para que os particulares concorrão com o Estado ao

\footnotetext{
${ }^{38}$ John Mawe comenta que o preço dos aluguéis no Rio de Janeiro era, em geral "tão elevado quanto em Londres". Mas atribuía tal fato "ao que parece, à falta de materiais de construção e ao alto preço da alvenaria". (1978: 82).
} 
aterro das novas ruas, sem que por isso soffrão ao depois as suas propriedades; demarcar a direcção, e largura das ruas; e tudo o mais que no meio de semelhantes cuidados se julgar necessario para extinguir huma causa tão oposta á nossa boa existência (1808: 12).

Outros "melhoramentos" na cidade seriam necessários para dar a ela aparência de realeza. Para isso foi preciso criar "formas novas" que levassem a cabo a idéia. Em junho de 1808 cria-se o Jardim da Aclimatação (mais tarde conhecido como Jardim Botânico, depois de atender pela alcunha de Real Horto), com o intuito de aclimatar espécies de diferentes partes do Império português. É nessa época que se plantam as primeiras mudas de palmeira imperial (Roystonea oleracea), que viria a ser o símbolo do Reinado de d. João no Brasil e, depois, do Império do Brasil. (Bediaga, 2007: 1132).

Frente à necessidade de "civilidade" exigida pela sociedade de Corte, urgia implantar alguns "melhoramentos" tanto na cidade quanto nos seus "cidadãos". Desse modo, para além do ordenamento do espaço, se efetivou o policiamento de seus habitantes, principalmente frente ao aumento do número de homens livres que "vagueavam" pela cidade. Na mesma direção, buscou-se maior polimento, através da divulgação dos bons modos e comportamentos, por meio da Impressão Régia e dos manuais de civilidade, assim como pela (pouco abrangente) educação formal. (Pechman, 2002)

A teatralidade da sociedade de Corte traz para a colônia o mundo dos sobrados e uma nova ordem de aparências e de convivência pública, diferente da vida isolada das fazendas. $\mathrm{O}$ enorme aumento da população acarretaria a necessidade de se conviver na cidade, em lugares como o Passeio Público, obra do tempo do vice-rei Luis de Vasconcelos, ou ainda no Real Theatro São João, criado em outubro de 1813. O teatro era um local de elite, por excelência, mas de uma elite que trazia seus escravos à tiracolo, como sinal de distinção. Nesse lócus de encontro do distinto eram comuns alguns "maus comportamentos" e até atentados físicos, como uma pedra atirada em um ator (Malerba, 2000).

Conforme coloca Robert Moses Pechman: 
Por não conceber o diferente da família, por não admitir a possibilidade do outro, o senhor não negocia, situa-se aquém do pacto, não produz política. No caso da sociedade de corte, ao contrário, o outro é a condição fundamental para a existência do sujeito, na medida em que todos são personagens e a vida social é pura teatralização, exposição pública. (Pechman, 2002: 53, 54).

O convívio público que a cidade engendra faz confrontar o senhor patriarcal com todos os elementos que também eram parte da sociedade colonial - os outros ${ }^{39}$ - fossem escravos, nobres, comerciantes, artesãos, artistas, viajantes, ciganos, estrangeiros... E ao mesmo tempo em que há uma normatização do que se passa na rua, no sentido de coibir abusos de particulares, há também a brecha que surge ao se diminuir o controle patriarcal da "casa-nobre", abrindo uma possibilidade transgressora, que podia significar perigo para as classes dominantes (vide assaltos ou o episódio da pedrada relatado por Malerba)

Co-habitavam o mesmo espaço social uma "turba pigmentada de vários tons e a realeza". Era novidade para a sociedade de corte "a presença daquela fração, aliás numericamente nada desprezível, da malta preta e mestiça que se encontrava fora da esfera doméstica" (Malerba, 2000: 135-136). Há de se notar que esta convivência entre diferentes estratos sociais na cidade era possibilitada justamente pelo fato de a distinção social se encontrar na aparência.

Percebe-se, também, como à Corte branca se fez necessária certa plasticidade, como por exemplo com a permissão da existência de um simulacro de corte negra, visando apaziguar as tensões sociais, como o caso das festas de coroação do rei e da rainha do Congo, que ocorriam no dia de Reis, de São Baltazar e de Nossa Senhora do Rosário, e

\footnotetext{
${ }^{39}$ Simmel (1950: 402-408) diz que o estranho (ou o estrangeiro) é aquele que está próximo e distante ao mesmo tempo; ou seja, não é alguém completamente de fora, mas sim quem está inserido na ordem de forma excludente, o que nos remete ao papel que cabiam aos escravos na sociedade colonial. Também é interessante refletir sobre a emergência deste espaço público urbano em que, além destes elementos socialmente próximos e distantes que eram os escravos, também conviviam os brancos próximos e distantes que eram os reinóis e os nascidos nesta terra. Como atesta Catherine Hall (2002), em seu trabalho sobre a Jamaica, as geografias coloniais se produziam na diferença, através do imperativo do distanciamento. Com o episódio único da transformação da colônia em metrópole ("uma das mais curiosas negociações que já ocorreram na história dos reinos e das cortes") se abalam os pressupostos até então estabelecidos e confortáveis desta diferença, exigindo readaptações que garantissem a distinção social.
} 
possibilitavam aos eleitos conduzirem sua própria corte trajados com coroa, manto, cetro (Karasch, 2000).

Isso pode ser lido como um exemplo da teatralidade dessa sociedade, ainda muito marcada pela saída barroca para a manutenção da ordem, que se dá pelo artifício. Na teatralização da vida, através de uma operação tipicamente barroca, o "novo" (e ameaçador) era incorporado e desviado para uma esfera inofensiva, onde se poderia imobilizar seus poderes de mudanças e garantir a conservação (Maravall, 1993; Barboza Filho, 2000).

A ordem das aparências do Rio de Janeiro joanino é retratada por Manuel Antônio de Almeida (1982), em seu famoso Memórias de um sargento de milícias, escrito em 1855, mas que se remete à sociedade fluminense no "tempo do rei". As relações entre essa nova ordem civilizada e a ordem colonial demonstram que havia um afrouxamento dos costumes à medida que, segundo análise de Antonio Candido (1993), ordem e desordem se imbricavam dialeticamente. Segundo esse autor, na trajetória dos personagens Leonardos - pai e filho - as formas espontâneas de vida social abrandam o choque entre a norma e a conduta, gerando uma penetração recíproca de extremos. Ainda, com a personagem do Major Vidigal (inspirada em uma figura real) temos a representação máxima da ordem e da hierarquia na aparência, mas que se revela essencialmente subvertida ${ }^{40}$.

As percepções magistrais de Almeida, assim como a análise de Candido, acrescentam novas iluminações sobre as hierarquias na passagem da colônia para o Império. Conforme Ilmar Mattos (1994: 109-124), no mundo colonial há hierarquias cristalizadas numa frágil sociedade dividida entre: o mundo do trabalho, constituído por escravos sem nenhum direito civil; o mundo da desordem, constituído por homens livres, pobres e cidadãos de segunda classe; e o mundo da ordem, composto por cidadãos de primeira classe, a quem caberia o ordenamento da sociedade. Vê-se que esses mundos se

\footnotetext{
${ }^{40} \mathrm{Na}$ seguinte cena, tem-se o "desvendamento" do duplo caráter do major, através de uma alusão às vestimentas. "O major recebeu-as de rodaque de chita e tamancos, não tendo a princípio suposto o quilate da visita; apenas, porém, reconheceu os três, correu apressado à camarinha vizinha e envergou o mais depressa que pôde a farda; como o tempo urgia, e era uma incivilidade deixar sós as senhoras, não completou o uniforme, e voltou de novo à sala de farda, calças de enfiar, tamancos e um lenço de alcobaça sobre o ombro, segundo seu uso. A comadre, ao vê-lo assim, apesar da aflição em que se achava, mal pôde conter um risada que lhe veio aos lábios". (Almeida, 1982: 156).
} 
entrecruzam, mas nem por isso deixa de haver hierarquia, dominação e exploração, pelo contrário, já que esses mundos se entrecruzam "por trás do pano".

No meio urbano, a escravidão se diferencia da escravidão rural, com a presença dos chamados "escravos a ganho", que seriam os que recebiam dinheiro de terceiros por serviços prestados. Ferdinand Denis comenta o comércio realizado por esses homens e mulheres, dizendo que era comum encontrar "pretas levando a cesta cheia de frutos, que acabam de colher nas quintas de seus senhores e vão colocar no mercado" (Denis, 1992: 126), indicando a possibilidade que existia, na cidade, do escravo circular livremente, apesar do citado policiamento que visava à manutenção da "ordem".

Segundo Leila Algranti (2002: 199), esses escravos faziam o serviço de vendedores ambulantes, suprindo a cidade "de todos os produtos necessários ao consumo doméstico básico: pão, leite, lenha, frutas e legumes, além de toda sorte de produtos manufaturados vendidos muitas vezes também a domićlio". Fica claro que o escravo, no contexto urbano, passa a se ocupar de atividades como o comércio e a manufatura, sendo muitas vezes treinados pelos seus senhores para isso. Podendo se deslocar pela cidade "eram por assim dizer 'donos' de seu próprio tempo", ainda que não fossem donos de seu próprio corpo. Esses escravos poderiam prestar seus serviços a quem bem entendessem durante esse tempo, "e recebiam diretamente pelos serviços prestados uma contrapartida em dinheiro". No fim do dia, deveriam pagar ao senhor uma quantia pré-estabelecida, do contrário recebiam castigos (Algranti, 2002: 200-1).

Os escravos ao ganho, somados aos homens livres, representavam o contingente cada vez maior de pessoas que viviam de serviços, biscates e empreitadas na cidade, assim como da prostituição. $\mathrm{O}$ aumento do policiamento e do controle se deu em função do medo representado por esse contingente, fortalecido pelo fantasma do haitianismo. É esta, inclusive, a faceta que os projetos de melhoramentos urbanos não conseguiam esconder: a do trabalho escravo. Enquanto as transformações espaciais buscavam civilizar a antiga aparência colonial e afirmar uma civilidade européia, a paisagem social cotidiana revelava a sua colonialidade. Segundo Kirsten Schultz: "a diferença 
mais gritante entre a antiga e a nova corte não era só a arquitetura ou as maneiras, mas o fato de a metade da população da nova corte ser escravizada" (2001: 121).

Ao olharem para as ruas do Rio de Janeiro, os viajantes se depararam com sua essência cotidiana mais latente: a quantidade massiva de escravizados africanos, ou descendentes, que realizavam todo o tipo de trabalho. Luccock relata que um estrangeiro que atravessasse "a cidade pelo meio do dia quase poderia supor-se transplantado para o coração da África" (1975: 75).

Enquanto em Portugal a escravidão havia sido abolida, pelos decretos de 1761 e 1773 (Schultz, 2001: 121), no Rio de Janeiro o tráfico de africanos somente aumentou. Segundo cálculo de Manolo Florentino (Fragoso \& Florentino, 2002), entre 1790 e 1830 desembarcaram cerca de 700 mil escravos no Rio de Janeiro, uma cifra extremamente grande, que representa, em apenas 40 anos, aproximadamente 1/5 do total de importação de africanos no Brasil entre o século XVI e o XIX.

Se o tráfico movimentava o dinâmico porto da cidade, após a abertura deste às "nações amigas" o comércio dinamizaria ainda mais o Rio de Janeiro. Tomada em Salvador, no dia 28 de janeiro, antes mesmo de o Monarca aportar no Rio de Janeiro, a medida de abertura dos portos foi das mais importantes do período joanino, modificando o funcionamento da economia colonial, com a ampliação do leque de negócios que se realizavam no porto do Rio de Janeiro.

Igualmente importante seria a publicação, em $1^{\circ}$ de Abril de 1808, de alvará assinado pelo príncipe regente d. João VI, anulava-se o alvará de 1785, afirmando serem as manufaturas e a indústria essenciais para a "riqueza nacional"41. A partir de então, a indústria têxtil, assim como a indústria de embarcações, seriam incentivadas pela Coroa,

\footnotetext{
41 "Eu o Príncipe Regente, faço saber aos que o presente alvará virem: que desejando promover e adiantar a riqueza nacional, e sendo um dos mananciais dela as manufaturas e a indústria, que multiplicam e melhoram, e dão valor aos gêneros e produtos da agricultura e das artes, e aumentam a população, dando o que fazer a muitos dos meus vassalos, que por falta deles se entregariam aos vícios da ociosidade", Colecção das Leis do Brazil de 1808. Rio de Janeiro: Imprensa Nacional, 1891: 10.
} 
ressaltando-se que indústrias de luxo ainda seriam restritas a Portugal, como percebe-se no discurso de José da Silva Lisboa em 1810:

O Brasil pode ainda por longo tempo ter muita indústria e riqueza, sem estabelecer as Fábricas refinadas, e de luxo que distinguem a Europa. As Fábricas que por ora mais convém ao Brasil são as que aproximadamente se associam à Agricultura, Comércio, Navegação e Artes da geral acomodação do povo ${ }^{42}$.

Boa parte dos estabelecimentos industriais fundados desde então no Brasil se localizavam na cidade do Rio de Janeiro, sendo a maioria deles classificados pela Junta de Comércio como oficinas artesanais independentes. Após o alvará, estabelece-se a Fábrica da Pólvora, na Lagoa Rodrigo de Freitas, no dia 13 de maio de 1808, aniversário do Príncipe Regente. Neste mesmo dia, é criada a Impressão Régia e o primeiro periódico do Brasil, a Gazeta do Rio de Janeiro, que seria uma ponte com as notícias vindas da Europa, e propagaria os informes oficiais da corte. Pela Impressão Régia se publicaria uma série de obras, sendo a primeira delas a já citada "Reflexões sobre alguns dos meios propostos, por mais conducentes, para melhorar o clima da cidade do Rio de Janeiro", escrita pelo médico Manuel Vieira da Silva.

Alguns meses depois, em outubro, se criava o Banco do Brasil, que segundo Gilberto Freyre (2000: 44, 45), teve grandes efeitos sobre a cidade, "modificando-lhe a paisagem social no sentido da urbanização; no sentido do domínio dos campos pela cidade" [e] "acentuando a gravitação de riqueza e energia para as capitais, particularmente para a Corte". Segundo Eulália Lobo (1978: 82), a criação do Banco do Brasil teve como objetivo custear as despesas do Estado, sendo "uma instituição de crédito organizada para aumentar o meio circulante, [que] representava uma vitória contra a mentalidade metalista dominante". Larissa Brown (1986: 36) reforça essa visão, dizendo que o alvará de criação do Banco deixava claro que o papel principal da instituição seria o de financiar os gastos públicos e não tanto estimular o comércio.

O Rio de Janeiro vinha vivenciando um momento de prosperidade desde fins do século XVIII, quando as políticas de diversificação de culturas haviam surtido efeito e a cidade se afirmava enquanto centro comercial. Desde 1790, um grupo local, os negociantes de

\footnotetext{
${ }^{42}$ José da Silva Lisboa. Observação sobre a Franqueza da Indústria e Estabelecimento de Fábricas no Brazil. Rio de Janeiro, Impressão Regia, 1810. (apud Soares, 2002).
} 
grosso trato, controlava a lucrativa atividade do tráfico de escravos (Fragoso \& Florentino, 2002). Além disso, um comércio de cabotagem, "ligando o Rio de norte a sul, de Cabo Frio a Pernambuco, de Ilha Bela ao Rio Grande do Sul", já estava montado, dependendo quase estritamente de negociantes brasileiros.

Com a vinda da Corte, o porto do Rio de Janeiro intensificou as suas atividades, movimentando novos negócios:

Para a cidade do Rio de Janeiro, a transferência da corte consolidou tendências que tinham se iniciado no século XVIII: uma proeminência política emergente, formalmente reconhecida em 1763, quando a capital do Brasil se mudou de Salvador para lá, e o crescimento da população, da sua comunidade mercantil, e do volume de bens intercambiados no porto e no mercado. Entre 1808 e 1821, a população da cidade dobrou, atingindo quase 80 mil pessoas. O número de negócios no varejo aumentou mais de $100 \%$ e, em 1808, logo após a abertura dos portos decretada pelo Príncipe Regente, a entrada de navios no porto subiu quatro vezes em relação ao ano anterior (Schultz, 2000: 8).

Esta conjuntura era muito favorável aos negociantes da praça do Rio de Janeiro - que segundo João Fragoso (1992) representava a verdadeira elite local - que ainda por cima eram agora contemplados com a presença do rei e todas as possibilidades de aproximação à máquina do Estado e à esfera simbólica da nobreza. Para Iara Lis Souza (1998: 45).

se, externamente, se reorganizavam as linhas comerciais do Brasil com a Europa, internamente, a corte foi uma oportunidade para que negociantes locais deslanchassem na vida social, política, conquistando prestígio e aumentando sua riqueza (Souza, 1998: 45).

\section{Negociando a convivência}

Na praça comercial do Rio de Janeiro atuavam três tipos de comerciantes: os miúdos (chamados de "retalhistas", "homens de vara" ou "mercadores de loja"); os comerciantes de "grosso trato" ou de "sobrado", destacados importadores e exportadores, senhores de grande cabedal; e os "capitalistas" ou "aqueles que viviam de seus bens ou rendas", participando eventualmente de compra e revenda de mercadorias, 
sem se organizarem em firma estabelecida. (Cavalcanti, 2004: 75, 76). Ainda que lhe faltasse a civilidade e o convívio cortesão, esta elite fluminense (não importa se nascida em Portugal ou no Brasil, mas assentada no Rio) vinha enriquecendo consideravelmente desde fins do século XVIII.

O lendário Brás Carneiro Leão, por exemplo, um dos mais ricos comerciantes fluminenses, atuava num vasto raio de influência, emprestando dinheiro a juros a pequenos comerciantes. Este comerciante de grosso trato:

administrava diversos negócios ligados à importação e exportação, possuía engenhos, navios e numerosos imóveis urbanos de grande valor. Natural do Porto, Carneiro Leão mantinha ligações comerciais no Reino, com as cidades de Lisboa e sua cidade natal, além de Angola e Benguela, na África. No Brasil, atuava no Rio de janeiro, Salvador, Recife, Vila Rica, Sabará e Serro do Frio, entre outras localidades. (Cavalcanti, 2004: 76)

Alcir Lenharo (1992) destaca que havia dois grupos ligados ao comércio na praça do Rio de Janeiro: um, procedente da nobreza ou da burocracia de Estado, ligado ao alto comércio, muitas vezes ao tráfico; o outro, abastecedor do mercado carioca, influente politicamente em nível local e provincial mas não reconhecido pela nobreza, sendo que muitos de seus membros são proprietários que comerciam sua própria produção (sendo difícil precisar a divisão entre a produção para subsistência e para exportação). Vários destes últimos eram provenientes do Sul de Minas, mas também de outras regiões mineiras, paulistas e fluminenses.

Do ponto de vista desta elite local não nobilitada, a presença do monarca representou uma possibilidade concreta de ampliar os negócios e ainda valer-se do prestígio de ser agraciado por honrarias reais. Esta elite não era escolada em etiqueta, tampouco portuguesa "pura", e se pautava em modos mesclados ${ }^{43}$, alguns mesmo orientais. "Não obstante esses traços híbridos de aparência, abunda[va]m evidências da avidez dos brasileiros pela nobilitação" [...] "Onde agora havia uma corte, ser nobre era o passaporte para ela", (Malerba, 2000: 189). Era a figura do Monarca que conseguia

\footnotetext{
43 "Uma senhora vai à missa acompanhada por numerosos escravos adornados com riqueza, e muitas vezes em voltando para casa assenta-se n'uma esteira, onde come, com a mão, peixe salgado e mandioca" (Denis, 1992: 139).
} 
agrupar sob a Coroa súditos de diversas regiões, recebendo-os com generosidade patriarcal.

A nobreza portuguesa, entretanto, "atingira as praias transatlânticas quase que em estado de indigência, 'destituída de tudo, exceto a honra"”, segundo John Luccock (1975: 68). Seria, então, o casamento perfeito, da elite "impura", mas rica, e dos nobres falidos, porém detentores de imenso capital social. É curioso que o viajante inglês avalia essa situação com olhos de comerciante e pastor protestante, que lhe conferiam medidas a partir do cálculo racional e do controle dos gastos, muitas vezes zombando da valorização simbólica concedida às honrarias. Assim, dizia que "os ricos brasileiros tinham casa e coisas boas que pôr de lado; nisso é que eles levavam vantagem. Eram visitas bem-vindas na Corte, não só pelo desejo de lhes conquistar a amizade mas mais ainda por terem eles a capacidade de retribuir honrarias ocas com benefícios maciços" (Luccock, 1975: 68) [grifo nosso] ${ }^{44}$.

Segundo Jurandir Malerba (2000: 225): "coube à elite econômica fluminense socorrer os cofres públicos nas urgências com a instalação e manutenção da maquina administrativa e da corte parasitária e faminta de distinção que chegou com o soberano". O caso de Elias Antonio Lopes foi um destes: "a doação de Lopes e a resposta do Príncipe Regente mostraram que a transferência da corte enobreceu os habitantes do Rio, literal e figurativamente" (Schultz, 2001: 81). Lopes teve como recompensa cargos e títulos, sendo nomeado Fidalgo da Casa Real (apesar das suspeitas sobre sua origem ilegítima) e enterrado como Cavaleiro da Ordem de Cristo, além de ter sido membro da Real Junta de Comércio e Agricultura.

A distribuição de mercês foi incrivelmente maior no período joanino no Brasil (Malerba, 2000: 216). E se primeiro elas eram destinadas mais restritamente aos portugueses do reino (afinal, era necessário agradar também aos que haviam seguido o Príncipe Regente, e depois Rei, em sua mudança para os trópicos), logo elas passaram a

\footnotetext{
${ }^{44}$ Um outro viajante inglês comenta o excesso dos tiros de canhão frente ao menor motivo de celebração e mesmo na falta dele. Com ironia desdenha do "gosto pelo gasto de pólvora", numa ação significativa em que a racionalidade econômica mede um ato simbólico: "The portuguese appear to be extremely found for expending their powder; hardly an hour of the day passed without the sound of cannon in some direction or other" (Brackenridge, 1820 apud Malerba, 2000)
} 
agraciar também os nascidos em terras brasílicas. Proliferavam novos marqueses, viscondes e barões vivendo de aparências, com pouco conforto doméstico.

Ao conceder honrarias a seus vassalos, d. João VI não inaugurava nada de novo, somente perpetuava essa prática antiga do Antigo Regime. Porém, essas dádivas reais teriam papel fundamental no Brasil, pela necessidade de reconhecimento e fidelidade dos seus ricos vassalos. As representações públicas, como o beija-mão, eram ocasiões especiais para este tipo de concessão, nas quais abundavam diversos tipos de requerimentos.

Logicamente, este mecanismo dadivoso gerava disputas e vaidades. A expectativa de ser contemplado com alguma graça aumentava a cada aniversario real, festa pública ou vitória militar. No trabalho de Emílio Rodriguez Lopez (2004), percebe-se como a presença do Rei e o ritual cotidiano da política das festas públicas, ditadas por calendário cheio, eram a expressão dessa sociedade, que tentava se propagar no tempo através de ajustes e concessões. Ao investigar a forma e a periodicidade em que se davam tais festas, a origem dos financiamentos, Lopez acaba mostrando que há uma secularização do calendário e uma pulverização do poder.

Os gastos imensos com as festas, bancados pelos comerciantes enriquecidos e desprovidos de nobreza, eram recompensados pela Coroa com o capital simbólico das mercês, graças e títulos honoríficos. Por sua vez, este capital ainda era valorizado, visto que as práticas de sociabilidade legitimavam tais lógicas.

As novas e duplicadas instituições criadas no Rio de Janeiro, como o Desembargo do Paço, a Casa da Suplicação do Brasil, a Junta do Comércio, o Erário Régio e o Banco do Brasil representavam excelentes oportunidades para o serviço real. (Schultz, 2001: 83). Além disso, os negociantes de grosso trato também ocupavam cargos no Serviço do Paço e no Senado da Câmara (Gouvêa, 1998).

Para Iara Lis Souza, os negociantes de grosso trato:

se aproximavam do rei e se transformavam, mais e mais, em homens de corte, sendo lisonjeados com títulos, mercês, honrarias, nomeações, condecorações, tenças e serventias de ofícios, geralmente distribuídos em alguma ocasião festiva, como o 
aniversário, batizado ou casamento de algum membro da família real. Essas honrarias vinham, em geral, acompanhadas de ganhos econômicos, como na concessão de um serviço do Estado, o acesso à terra e à sua propriedade (Souza, 1998: 47).

Ou seja, não somente de "honrarias ocas" (como definiu Luccock) viviam os negociantes que prestavam serviços à Coroa. Além de todo o prestígio que a entrada para o círculo de nobreza representava, a possibilidade de ser agraciado com um cargo, ou uma sesmaria, significava também a reiteração e o aumento de ganhos econômicos. Pode-se perceber a convivência de distintas racionalidades na regência desses sujeitos, em uma época de transição que ora pende para uma valorização do cálculo e do controle de gastos, ora demonstra a importância do prestígio e do capital simbólico sobre a racionalidade econômica.

Entre escalões do alto comércio, houve uma política "generosa" de D. João VI de doação de terras a poucas e ricas famílias. Em troca, as elites financiavam obras públicas e ajudavam na construção de uma infra-estrutura necessária à consolidação de uma centralidade na cidade do Rio de Janeiro. "Assim, incrementaram a construção de pontes e estradas ligando Rio-Minas-São Paulo, contribuindo para o crescimento comercial da região" (Souza, 1998: 47).

A capitania do Rio de Janeiro passaria por uma grande transformação, com algumas regiões, como os Campos dos Goitacases e o Vale do Paraíba vivenciando uma "mercantilização da terra que expulsava os antigos posseiros, os pequenos arrendatários e os índios, em favor da formação e estabelecimento de uma propriedade rural particular que produzisse em grande escala" (Oliveira, 1986). Outras, como os sertões do Macacu, antes ocupados por contrabandistas, seriam incorporadas à lógica da Coroa, ganhando equipamentos de controle do território e sendo apropriadas por "vassalos" do rei. 


\section{A CIDADE E SUA REGIÃO}

\subsection{Introdução}

Segundo Aires de Casal, na sua Corografia Brasílica (1976), publicada em 1817, a província do Rio de Janeiro à época poderia ser dividida em duas regiões: "beira-mar" e "serra acima". Na primeira divisão, costeira, estariam os distritos de Ilha Grande, Rio de Janeiro, Cabo Frio e Goitacazes. Na segunda, os distritos de Paraíba Nova e Cantagalo.

No "beira-mar", o distrito de Ilha Grande incluía as vilas de Angra dos Reis e Parati. O distrito do Rio de Janeiro englobava a cidade do Rio de Janeiro e as vilas de Maricá, Santo Antonio de Sá de Macacu, Magé e Vila Nova de São João del Rei. Já o distrito de Cabo Frio a cidade de Cabo Frio e a vila de São João de Macaé. E o de Goitacazes as vilas de São Salvador dos Campos de Goitacazes e São João da Paraíba. Na "Serraacima”, o distrito de Cantagalo contava apenas com uma vila, de mesmo nome. E o distrito de Paraíba Nova era composto pelas vilas de São João Marcos e Resende.

Em recenseamento de 1816, feito por Manuel Pedro Gomes ${ }^{45}$, listam-se as mesmas vilas (com exceção das do distrito de Goitacazes), com os respectivos números de fogos e de habitantes.

\begin{tabular}{|c|c|c|}
\hline Vilas e Cidades/ capitania do Rio de Janeiro & Fogos & Habitantes \\
\hline 1. V ${ }^{\mathrm{a}} \mathrm{S}$. João de Macahe & 451 & 4.834 \\
\hline 2. Cd. de Cabo Frio & 1.225 & 9.553 \\
\hline 3. V $V^{a}$ de Maricá & 1.421 & 8.760 \\
\hline 4. V Vova de S. José del Rei & 142 & 1.214 \\
\hline 5. V $\mathrm{V}^{\mathrm{a}}$ de Sto. Antonio de Sá & 2.767 & 23.881 \\
\hline 6. V $V^{a}$ de Magé & 1.319 & 10.608 \\
\hline 8. $\mathrm{V}^{\mathrm{a}}$ do Cantagallo & 297 & 2.784 \\
\hline 9. V $\mathrm{V}^{\mathrm{a}}$ do S. João do Príncipe & 625 & 6.502 \\
\hline 10. $\mathrm{V}^{\mathrm{a}}$ de Resende & 500 & 3.812 \\
\hline 11. $V^{a}$ de Angra dos Reis & 1.590 & 15.059 \\
\hline 12. $V^{a}$ de Paraty & 1.167 & 7.564 \\
\hline
\end{tabular}

\footnotetext{
${ }^{45}$ Mapa estatístico do Rio de Janeiro, 1816. Manuel Pedro Gomes. Biblioteca Nacional do Rio de Janeiro, Manuscritos, Ms I - 31, 19, 11.
} 
Nesse mapa estatístico, que descreve ainda as freguesias e os engenhos que se encontravam dentro do termo de cada vila ou cidade, também se vislumbram os caminhos que cortavam cada região, entre os quais podemos destacar quatro principais direções: a estrada para Campos, a estrada para São Paulo, a estrada para as Minas e a recém-aberta estrada para Cantagalo. Pela descrição de Gomes, a capitania parecia bem interligada pelos caminhos existentes.

Porém sabe-se que muitas destas rotas eram simples picadas na mata, com condições de tráfego variáveis, sujeitas às intempéries da natureza. Afinal, a interiorização da ocupação da capitania do Rio de Janeiro remonta apenas ao século XVIII, com a exploração aurífera; até então a maritimidade da instalação portuguesa havia prevalecido. Somente após a chegada da corte ocorre uma intensificação da ocupação da capitania do Rio de Janeiro, com abertura de caminhos, fundação de novas vilas, derrubada de florestas e constituição de novas unidades de produção (Oliveira, 1986: 76).

\subsection{Caranguejos à beira-mar}

É notória a percepção de que a colonização portuguesa no Brasil foi marcada por sua "maritimidade", ou seja, pela instalação de núcleos incrustados no litoral. Frei Vicente Salvador (1918:19), escrevendo em 1627, afirmou que os portugueses, "sendo grandes conquistadores de terras, não se aproveitam delas, mas contentam-se de as andar arranhando ao longo do mar como caranguejos". Sérgio Buarque de Holanda, em seu

clássico texto "O semeador e o ladrilhador", explicou tal fato pelo suposto espírito aventureiro da dominação portuguesa, "que cuidou menos em construir, planejar ou plantar alicerces, do que em feitorizar uma riqueza fácil e quase ao alcance da mão" (1995:95). Assim, presa a essa busca por riquezas imediatas, a colonização lusa na América teria tido dificuldade em penetrar o interior do recém-descoberto território. Afinal "o que o português vinha buscar era, sem dúvida, a riqueza, mas riqueza que custa ousadia, não riqueza que custa trabalho" (Holanda, 1995:49). Dentro deste contexto, incentivava-se a construção de vilas à beira mar e rio, como forma de garantir uma ocupação restrita aos sítios litorâneos e, portanto, mais próxima à Metrópole. 
Outros autores destacam, para além do espírito feitor do português, diferentes impedimentos para a interiorização da colonização lusa na América. Aroldo de Azevedo (1956), por exemplo, destaca que a presença de escarpas abruptas no litoral meridional da América Portuguesa constituía por si só uma barreira natural que escondia uma região intransponível e acentuadamente montanhosa. Mas seria justamente transpondose uma parte do relevo bem dissecado da Serra do Mar que surgiria Piratininga, primeiro núcleo interiorizado, o que o autor justifica pela prévia existência de uma trilha indígena e pela colaboração de seus utilizadores.

Já Antônio Carlos Robert Moraes (2000) esclarece que desde o início havia interesse português pela interiorização, o que é demonstrado não só pelo caso da fundação de Piratininga (possível pela existência prévia de um caminho), mas também por outras entradas nas capitanias meridionais. Para este autor:

Ao contrário dos espanhóis, os portugueses não se defrontaram com uma estrutura territorial interiorizada preexistente, nem com uma rede urbana que induzisse uma instalação na hinterlândia. Onde preexistia, nas sociedades encontradas, uma relação mais regular entre a vida litorânea e o interior, como no caso das capitanias mais meridionais, rapidamente os colonizadores apropriaram-se dos itinerários e caminhos existentes. (Moraes, 2000:307).

Ainda, Moraes destaca que, a partir do momento em que houve suposição de riqueza que justificasse os gastos de um empreendimento de entrada no interior, as expedições começaram a se avolumar. Esse movimento de interiorização pode ser percebido desde o século XVI, mas só ganha maior relevância a partir de final do século XVII, quando são descobertas importantes jazidas de metais preciosos na atual região de Minas Gerais.

Note-se que este fato não diminui a importância dos núcleos litorâneos enquanto articuladores da rede de trocas do sistema colonial. Afinal, como a colonização tinha na articulação com a metrópole e nas trocas atlânticas sua principal razão de ser, mantevese um padrão urbano fortemente concentrado na costa brasileira, fato que pode ser percebido até os dias de hoje. 
No pensamento social brasileiro do século XX sobreviveu uma idéia de litoral civilizado, pois mais próximo à "fonte irradiadora" das luzes civilizatórias, em detrimento de um interior pouco conhecido e ocupado por índios "bárbaros". Para Moraes (2003: 50), a partir de temática desenvolvida por Candice Souza (1997):

A dualidade mais recorrente no pensamento social brasileiro opõe o sertão ao litoral, tomando primeiro termo como sinônimo de hinterlândia e, portanto, cubrindo todo o vasto interior do território nacional. Dessa perspectiva o contraponto se estabelece na zona costeira, considerada referente negativo (“o outro”) na caracterização da condição do sertão.

Em um texto do geógrafo Aroldo de Azevedo, escrito na década de 1950, percebe-se a dualidade do "sertão desconhecido" e das costas que ofereciam mais "conforto" e "civilização":

fixar-se junto às águas do Atlântico, dessas mesmas águas que também banham as costas lusitanas, constituía, até certo ponto, um gesto de sobrevivência e manifestação de uma esperança; afastar-se desse litoral e embrenhar-se pelo sertão desconhecido, planalto adentro era sujeitar-se a perigos de toda ordem e a contratempos inimagináveis, era expor-se aos ataques da indiada hostil e abdicar ao mínimo de conforto que a civilização podia oferecer. (Azevedo, 1956:15)

No caso da capitania do Rio de Janeiro, a presença portuguesa se manteve restrita a núcleos litorâneos por muito tempo. A ocupação da costa fluminense se deu inicialmente com a fundação das feitorias de Nossa Senhora da Assunção do Cabo Frio e São Sebastião do Rio de Janeiro, em 1504, por Gonçalo Coelho, como entreposto para as atividades de extração do pau-brasil e da pimenta (Bernardes \& Soares, 1964). Nos primeiros trinta anos, já era possível encontrar, nos arredores da feitoria, algumas plantações de cana de açúcar, cujo suco era utilizado para tratamento do escorbuto, doença que costumava vitimar os homens do mar. Todavia, as tentativas de construção de engenhos não foram bem sucedidas, sendo todos destruídos pelos índios tamoios, que "habitavam, no litoral, a área compreendida entre o Rio Macaé e as proximidades de Angra dos Reis" (Bruno, 1967: 16).

O porto da feitoria do Rio de Janeiro era visto como boa parada para a rota do Prata e mesmo a das Índias. Alberto Lamego esclarece que o litoral fluminense era composto de 
extensa faixa de restingas "à míngua de bons ancoradouros", constituindo-se a Guanabara numa exceção (Lamego, 1964: 148). Além de ancoradouro profundo, a Baia da Guanabara representava também um abrigo seguro para as embarcações (Bernardes $\&$ Soares, 1964). Com a crescente presença francesa na costa fluminense, a necessidade estratégica de garantir soberania desse porto levou às primeiras mobilizações lusas de povoamento do local, uma vez que era necessário garantir o funcionamento das rotas do Atlântico, assim como a soberania sobre aquelas terras ainda desconhecidas.

Excedendo a atuação marítima, os franceses chegaram a se fixar na Guanabara por dez anos (1555-1565), tentando estabelecer a França Antártica. Foram expulsos somente numa segunda expedição lusitana, liderada por Estácio de Sá, após a frustrada tentativa liderada por Mem de Sá, governador-geral da Colônia. As expedições foram acompanhadas pelos padres Manuel da Nóbrega e Anchieta, como incentivo aos soldados, o que demonstra a clara conjunção dos poderes militares e religiosos no processo de colonização.

Para Alberto Lamego, com a fundação da cidade de São Sebastião do Rio de Janeiro já se anunciava uma "grande sina" para a Guanabara, que era "um portal aberto para a expansividade dos planaltos". O mesmo autor coloca que, "rodeados de serras estrategicamente bem dispostas, os senhores da Guanabara fortificada seriam inderrotáveis, num reduto de antemão fadado à unificação de seus esforços colonizadores". Destinando, já nos primeiros anos de colonização lusa, a Guanabara a ser "capital natural" de um "imenso país" (Lamego, 1964: 148, 149, 160), o autor, num claro exemplo de anacronismo, destitui todo o processo de formação territorial de sua historicidade $^{46}$

A instalação da cidade de São Sebastião do Rio de Janeiro, em 1565, se deu inicialmente no Morro Cara de Cão, sendo transferida logo após, em 1567, para um sítio mais seguro, o Morro de São Januário (do Castelo), onde foi erguida uma fortificação. O calmo abrigo para as embarcações satisfazia as exigências militares e a península ocidental úmida, assim como os pântanos que rodeavam o morro, contribuía para a

\footnotetext{
${ }^{46}$ De qualquer modo, o referido autor nos concedeu boas fontes para análise, ainda que seu relato se faça, como mencionado, de forma a crer em um processo evolutivo, cujo fim já pode ser intuído de antemão.
} 
inexpugnabilidade do local. Em volta do colégio dos jesuítas (Lamego, 1964: 160) se organizava a vida colonial, espalhando-se os habitantes pelas ladeiras do morro.

Paralelamente, os vales pantanosos do Recôncavo Carioca também passam a ser ocupados, alastrando-se alguns rebanhos de gado pelas úmidas planícies, assim como lavouras de cana-de-açúcar e de mandioca. Logo em seguida à fundação da cidade do Rio de Janeiro, cria-se o povoado Magepe (Magé), a beira do rio Magé, que desemboca na Guanabara, e algumas sesmarias são concedidas a povoadores nas margens dos seguintes rios: Magé, Suruí, Iguaçu e no curso do alto Macacu (todos desembocando na baía).

A partir da segunda metade do século XVI, a economia regional começa a se diversificar timidamente. Além da exploração do pau-brasil, que figurava ainda como atividade principal, houve progressos na indústria de açúcar. Destaque-se também a formação de pequenas indústrias caseiras, de fiação e tecelagem nas aldeias jesuíticas. A ocupação do litoral próximo à Baía da Guanabara se intensifica, com concessões de sesmarias às margens dos rios Saracuruna, Matuapira (a leste da Guanabara) e Tapacorá, em 1578, enquanto que na Praia Grande (Niterói), funda-se a aldeia jesuítica São Lourenço (1568), englobando grandes extensões de terras e reunindo muitos índios ${ }^{47}$.

Neste movimento, porções mais longínquas do litoral fluminense foram sendo gradualmente ocupadas, incluindo ações de extermínio de grupos indígenas, como foi o caso dos tamoios, nas redondezas de Cabo Frio, com a ação do governo de Antômio Salema (1575). A justificativa dada para esse caso específico foi o combate ao comércio realizado entre os tamoios e os corsários franceses; porém o contrabando não cessou, uma vez que os goitacás aproximaram-se do litoral e passaram a realizar o escambo do pau-brasil com os franceses, estabelecidos em Cabo Frio desde a expulsão da cidade do Rio de Janeiro ${ }^{48}$. Além disso, a presença holandesa nas redondezas também se fazia sentir, o que levou, após quase cinqüenta anos, a uma ação efetiva de expulsão dos

\footnotetext{
${ }^{47}$ Essa aldeia, juntamente com a Aldeia de São Barnabé, a sete léguas da cidade do Rio de Janeiro, reunia três mil "almas", de acordo com o Padre Fernão Cardim, que visitou a região na última década do século XVI. (Bruno, 1967: 33).

48 "nas terras de Cabo Frio os franceses continuavam a freqüentar, naturalmente menos amiúde e com menor proveito". Capistrano de Abreu, apud Lamego, 1946: p.83.
} 
estrangeiros e uma aliança com os goitacás, que ocupavam a costa até a fronteira com a capitania do Espírito Santo, ao sul da barra do rio Itabapoana.

Assim, em 1615, a feitoria eleva-se diretamente à condição de cidade, que nasce juntamente com a Capitania de Cabo Frio, esta se estendendo até a foz do rio Macaé. É interessante notar que ambas as feitorias, de Cabo Frio e do Rio de Janeiro, nascem como entreposto comercial, por serem bons ancoradouros no litoral fluminense, e são elevadas à condição de "cidade" por razões estratégicas, frente à ameaça da conquista territorial francesa.

Após o extermínio dos tamoios e a expulsão dos "inimigos", pode-se dizer que ocorre a "pacificação do território costeiro entre a cidade do Rio de Janeiro e o sítio de Macaé" (Bruno, 1967: 32). Isso permitiu o povoamento de outras localidades ao redor da nova cidade: em 1615 funda-se a povoação de Macaé e em 1629 forma-se o aldeamento de São Pedro (atual São Pedro da Aldeia), ao norte da Lagoa de Araruama, bem próximo a Cabo Frio. A cidade de Cabo Frio, apesar do título, constava de alguns pescadores, "uma fortaleza sem gente, uma dúzia de moradores portugueses e uma aldeia de índios" (Lamego, 1946: 87). As atividades econômicas giravam em torno da pesca e da extração da madeira, havendo bons resultados também com o anil. Como as restingas destinavam aos seus ocupantes terras muito avaras, ruins para a agricultura, a tendência foi a organização da pesca e do sal, cuja produção já em 1627 foi notada por Frei Vicente, mas logo sofreria com a proibição, em 1655, da extração de sal em qualquer parte do Brasil (Bruno, 1959).

Enquanto isso, nas proximidades da foz do Paraíba do Sul, mais ao norte, também surgiram novos povoados, como o que daria origem à vila de São João do Paraíba (1677), futura São João da Barra, assim como o de Atafona (vizinho a São João do Paraíba). Na mesma região formou-se o povoado de Santo Antônio de Guarulhos, em 1672. Fora o caso de Atafona, pioneira povoação da região, as outras ocupações se deram após a "pacificação" e a concessão de sesmarias aos "Sete Capitães", homens que haviam "lutado contra franceses e tamoios". Estes homens 49 , abastados moradores do Rio de Janeiro - alguns deles senhores de engenho na Guanabara -, haviam reclamado à

\footnotetext{
${ }^{49}$ Os sete capitães eram: Miguel Aires Maldonado, Miguel da Silva Riscado, Antônio Pinto Pereira, João de Castilho, Gonçalo Correia de Sá, Manuel Correia e Duarte Correia. (Lamego, 1946).
} 
Coroa a falta de gado na região, propondo que lhes fossem concedidas sesmarias na capitania abandonada de São Tomé, "aonde constava haver grandes campinas". Com resposta afirmativa do Reino, em 1627 foi concedida uma sesmaria "desde o Macaé, correndo a costa, até o rio que se chama Iguaçu, e para o sertão até o cume das serras" (Bruno, 1967: 35)

Após uma primeira viagem de reconhecimento, os capitães perceberam que adentrandose no interior do rio Paraíba do Sul, havia boas planícies para criação do "cavalar" e do "vacum". Inicia-se assim o povoamento da região ao norte da Lagoa Feia, onde porções de terra passam a ser arrendadas para a atividade pecuária. $\mathrm{O}$ foco principal do povoamento foi São Salvador dos Campos de Goitacases, povoação cujos habitantes tentaram elevar a vila, por ter já setenta vizinhos em 1652. Mas somente em 1673 isso ocorreria, pois homens poderosos do Rio de Janeiro, "que tinham ali sítios e currais e cujos interesses se opunham aos dos moradores da planície" tornaram mais difícil a negociação (Bruno, 1967: 36) ${ }^{50}$.

Em meados do século XVII, há a seguinte situação produtiva: a cultura da cana adquiria mais força, com a multiplicação dos engenhos em torno da Guanabara, contabilizandose cerca de quarenta engenhos na região. Nesta época monta-se o primeiro engenho na região de Campos, que povoava-se com gado, mas demoraria ainda alguns anos para afirmar-se o ciclo do açúcar na planície dos Goitacases. Nesta região, além da carne salgada e do couro dos bois, também produziam-se queijo, farinha e algodão (Lamego, 1945: 76).

Outra indústria que ganhava importância era a da construção naval, iniciada em 16591660, ainda com pequenas dimensões, em Angra dos Reis e oficializada com a ordem régia para a construção de um estaleiro de proporções consideráveis em Ilha Grande. Ainda, as vizinhanças de Magé, ao fundo da Guanabara, aparecem como local de maior

\footnotetext{
${ }^{50}$ Segundo A. R. Lamego (1946), disputas intensas pela terra ocorreram nos Campos de Goitacases, uma vez que o governador do Rio de Janeiro, Salvador Correia de Sá e Benevides, doa a seus filhos (Viscondes de Asseca) a capitania de São Tomé, depois de algumas sesmarias terem sido doadas aos sete capitães. Além disso, desentendimentos com os padres beneditinos também ocorreram, com acusações de apropriações indevidas de concessões alheias. Essa briga vai se estender pelo século XVIII, quando em 1752 a capitania do Paraíba do Sul é comprada pela Coroa e anexada, juntamente com a de Cabo Frio, à capitania do Rio de Janeiro.
} 
cultivo da farinha de mandioca, essencial na alimentação da época, e que eram também vendidas às naus que paravam no Rio de Janeiro a caminho de Angola (Lamego, 1945).

A pesca aparece como atividade importante, sendo estimulada no governo de Cristóvão de Barros (1572-1575). As tainhas e corimãs eram espécies cobiçadas, pescadas na embocadura do rio Magé, muitas vezes através da utilização do processo indígena de envenenar a água com timbó, uma planta que tinha efeito narcótico nos peixes, facilitando a pesca. Vendiam-se as ovas, depois de salgadas, prensadas e secas, para a Bahia e outros lugares, segundo relato de Frei Vicente, citado por Ernani Bruno (1967: 38). Além disso, a pesca da baleia, cuja indústria localizava-se em São Lourenço (Niterói), também era uma atividade de significação econômica, possuindo, desde 1583, contrato para exploração (Ellis, 1968).

Todas essas atividades centralizavam-se na cidade de São Sebastião do Rio de Janeiro, cujo porto foi adquirindo novas conexões comerciais e aumentando sua influência na porção meridional da Colônia, já a partir de fins do século XVI. Consolidando-se como cidade comercial, o Rio de Janeiro vivenciaria um período de êxito nas trocas mercantis, o que seria abalado, no entanto, com os conturbados acontecimentos que rondaram o início do século XVII, como a invasão holandesa e a Restauração das Coroas Ibéricas.

A presença constante de holandeses no Atlântico sul, que se torna mais persistente a partir da segunda década do século XVII, torna a navegação atlântica, que já era perigosa, ainda mais complicada, principalmente após a conquista de Recife. Ademais, com a Restauração Portuguesa, em 1640, interrompe-se o comércio platino (pelo menos na escala em que ele se realizava), e instaura-se um problema na praça comercial do Rio de Janeiro: a falta de numerário com o sumiço da prata ${ }^{51}$. Somando-se a isso a criação da Companhia Geral de Comércio e introdução do sistema de frota única anual, delineia-se uma delicada situação para a cidade, já que o livre comércio estava proibido e o açúcar passara a servir de moeda.

\footnotetext{
${ }^{51}$ Devemos lembrar, ainda, que o comércio com Buenos Aires havia gerado uma intensa articulação entre Rio de Janeiro e a costa africana para o abastecimento daquela cidade de escravos, o que motivou um período de crise só resolvida com o inicio da atividade mineradora. Afinal, o intenso tráfico de escravos não tinha como ser incorporado somente pelo mercado brasileiro. Alencastro, 2000: 109-112.
} 
As "infalíveis frotas anuais", das quais nos fala Ernst Pijning (2001), passam a não ser tão assíduas assim, segundo Maurício de Abreu (2000: 21). Este coloca que o sistema de frotas gerava muitas reclamações, pois "às vezes vinha com poucos navios, o que impossibilitava o embarque de toda produção(...); às vezes demorava-se por pouco tempo (...). Com efeito, houve anos em que simplesmente a frota não apareceu, gerando desabastecimento e crise generalizada na agricultura, pois os açúcares não tiveram saída".

Essa situação levou à desvalorização do açúcar, pois este produto só tinha valor quando chegava a frota e, por conta disso, os negociantes se recusavam a comprá-lo, ou o faziam por preços irrisórios. Todo esse processo acabou privilegiando os mais poderosos, que reservavam lugar nos navios e tinham preferência no embarque. Além disso, nunca os produtores conseguiam vender o açúcar a preço justo, o que criava ainda maiores dificuldades para produtores menos influentes.

A chegada das frotas no porto iniciava uma aceleração no ritmo da cidade, pois era preciso abastecer os navios a tempo para a viagem de volta, uma vez que a navegação, por ser dominada pelo sistema de ventos predominantes, necessitava de rapidez para a volta $^{52}$. Desse modo, o trânsito nos pequenos portos da baía da Guanabara aumentava de maneira a não haver barcas suficientes para o transporte, ocasionando aumento do frete dos barqueiros e muitas perdas, que se iniciavam já no caminho por terra das fazendas até o mar. $\mathrm{Na}$ própria cidade, com tamanha mudança no cotidiano, aumentava-se a vigilância e a repressão, pois os distúrbios públicos cresciam conforme a chegada de tantos homens do mar (Abreu, 2000).

E, contraste com esse período, a chegada do século XVIII representou para a cidade do Rio de Janeiro uma série de significativas mudanças. No início do século houve uma grande debandada de habitantes fluminenses para as minas, provocando um período de certa crise, que se acirrou com os ataques franceses de 1711, que deixaram a cidade

\footnotetext{
52 "os navios precisavam ser rapidamente reparados e abastecidos para a viagem de volta; a produção transportada das fazendas para a cidade; as caixas de açúcar pesadas no trapiche público, para pagamento de direitos, e embarcadas". (Abreu, 2000: 22).
} 
saqueada. Como resposta, intensificaram-se as medidas de segurança, como a construção de novos fortes (Bicalho, 1997) $)^{53}$.

$\mathrm{Na}$ baía de Guanabara, as comunicações internas da região começaram, no século XVIII, a utilizar em maior escala algumas vias fluviais. Os rios do Recôncavo, principalmente o Iguaçu, o Magé, o Piedade e o Estrela (atual Inhomirim) passaram a constituir as primeiras etapas de alguns dos caminhos que se dirigiam do Rio de Janeiro para o interior. Ao longo do trecho montanhoso entre Rio de Janeiro e Angra dos Reis formaram-se os povoados de Itaguaí (a partir de um aldeamento indígena), São João do Príncipe, (atual São João Marcos) e Rio Claro. No trecho a leste da Guanabara, rumo a Cabo Frio, formaram-se os núcleos de Porto das Caixas, Rio Bonito, Capivari e, na costa, Saquarema. Nos setecentos, apenas uma freguesia seria elevada a vila, Magé, em 1789, e nenhuma cidade seria criada.

Enquanto isso, na região de Campos de Goitacazes, após mais de um século de disputa pela terra e domínio incerto entre os herdeiros dos Sete Capitães, os descendentes do governador Salvador Correia de Sá e Benevides e os padres beneditinos, efetiva-se o domínio da Coroa em 1752, quando inicia-se a produção de cana em maior escala nessas planícies banhadas por lençóis de argilas aluviônicas, propícias à agricultura. Até então havia-se introduzido a gramínea com êxito, e já iniciava-se, a partir de 1730, um aumento no número de engenhos, basicamente de aguardente. ${ }^{54}$

Tanto que, com o aumento dos engenhos na zona de Campos, em 1730 passavam de vinte as embarcações (lanchas, sumacas e uma fragata) que faziam permanentemente viagens da foz do Paraíba para a baía da Guanabara (Lamego, 1945; Bruno, 1967). Após a incorporação da capitania à Coroa, esse número chegou a setenta embarcações, já que, nessa época, a região exportava para o Rio de Janeiro 15.600 cabeças de gado, 3.000 cavalos, 85 alqueires de farinha e "algumas centenas de caixas de açúcar". A evolução no número de engenhos se fez rapidamente, indo de 34 , em 1737, a 278, em

\footnotetext{
${ }^{53}$ Nascida sob o estigma da disputa colonial, a cidade do Rio de Janeiro "viveu, até inícios do século XIX, a experiência de um constante "estado de sítio", em que o medo se manifestava diante da chegada de frotas estrangeiras (Bicalho, 1997: 438). No início do século XVIII, quando um navio estrangeiro aproximava-se da baía, "um grupo ia a bordo levando um juiz apontado pela Coroa, um intérprete, um médico, dois oficiais militares de alto escalão e dois delegados das autoridades portuárias" (Pijning, 2001: 203).

54 “Em 1737, já pagam direito ao Visconde 34 engenhos e engenhocas". (Lamego, 1945: 76).
} 
1783, ou seja, em menos de cinqüenta anos os engenhos se multiplicaram por oito (Lamego, 1945: 76)

Ocorre, também, um decréscimo na exportação de gado, visto que quase todas as iniciativas dos habitantes da região voltam-se para a cana, sendo as melhores terras logo ocupadas. Segundo o mapa de Couto Reis, citado por Alberto Lamego, a massa de proprietários rurais se encontrava, em 1785, na zona de aluviões entre o Paraíba e a lagoa Feia, sendo escasso o povoamento ao norte daquele rio, na costa, e pelas margens de outros rios próximos. A produção campista chega a ultrapassar a da Guanabara já nessa época, nos anos de 1780, o que leva à execução da carta régia pelo Príncipe Regente, que ordenava que não fosse executados "os senhores de engenho da capitania do Rio de Janeiro, nem se façam penhôres, por seus credores nas fábricas dos ditos engenhos e das fazendas de cana" (Lamego, 1945: 70), extendendo aos produtores fluminenses privilégio antes concedido aos senhores de engenho da Bahia.

No início do século XIX, além de concentrar as exportações de uma vasta hinterlândia em seu movimentado porto, a cidade do Rio de Janeiro passa também a possuir um mercado consumidor mais abrangente, destacando a questão do abastecimento e estimulando produções de localidades próximas. Segundo Alcir Lenharo (1992: 20) havia três fontes de abastecimento da cidade do Rio de Janeiro na época: externa, interna de cabotagem e interna terrestre. As litorâneas eram as duas primeiras: a externa composta de gêneros vindo de Lisboa e Porto (sal, vinho, azeite, azeitona, sardinhas, bacalhau, vinagre, trigo, farinha de trigo) e também do Prata (carnes salgadas, toucinhos e sebo); e a interna de cabotagem, que tinha o Rio Grande e Santa Catarina como principais núcleos, o primeiro fornecendo carnes salgadas, couros, sebo, trigo e peixe, e o segundo milho, feijão, arroz, trigo, cebola e farinha de mandioca. A capitania de São Paulo também supria a cidade de açúcar e milho (de Santos e Iguape) e arroz (de Cananéia e Iguape) ${ }^{56}$.

\footnotetext{
55 Encontram-se os mesmos dados em Fálcon \& Mattos, 1972.

${ }^{56}$ Lenharo não menciona a Bahia como presença importante no abastecimento do Rio de Janeiro. João Fragoso e Manolo Florentino destacam que vieram para o Rio de Janeiro, nos anos de 1812, 1817 e 1822 , farinha, milho e feijão do sul baiano (2001: 150). Analisando as entradas de embarcações provenientes de outras partes do Brasil no porto do Rio de Janeiro, no ano de 1816, (listadas na Gazeta do Rio de Janeiro), podemos elencar os principais locais de origem, em ordem decrescente: Rio Grande, Campos, Ilha Grande, Rio de São João, Santa Catarina, Parati, Cabo Frio, Santos, Bahia e Macaé. Ou seja, a Bahia figurava entre as entradas, com pequena importância, e seus produtos principais eram: sal, amarras,
} 
Da própria capitania do Rio de Janeiro, tinha-se o seguinte quadro: Campos dos Goitacases fornecendo açúcar, aguardente e mel; Parati, com diversos gêneros como aguardente, feijão, milho, farinha de mandioca, café, toucinho e fumo; Itaguaí, com arroz, açúcar, farinha de mandioca, café; Ilha Grande, com açúcar, arroz, café e aguardente; Macaé, açúcar; Cabo Frio, açúcar, milho, feijão e aguardente; Guaratiba, milho, farinha de mandioca; e da Guanabara vinham, por pequenas embarcações, hortaliças, animais de pequeno porte e peixe.

O chamado "renascimento da agricultura" no Rio de Janeiro, porém, não se dá somente após 1808, mas se inicia após os primeiros sintomas de decadência das minas, quando voltam-se esforços para a exploração de riquezas brasileiras como fibras, madeiras, tintas, cereais, conforme coloca Corcino Santos (1980: 36). Este renascimento se manifesta também, como fruto dos ventos ilustrados, na tentativa de aumentar os ganhos com a colônia, gerando uma política de diversificação do setor agrícola. Alguns dos produtos propostos foram: arroz, café, trigo, anil, algodão, cochonilha, seda, cânhamo, couro, pigmentos, madeira para construção naval, essências e outros materiais para medicamentos e perfumarias (Cavalcanti, 2004).

A primeira iniciativa se dá com a introdução da cultura do arroz, que já em 1756 alcançava um bom nível de produção, chegando, a partir de 1759, a alcançar boa posição na lista dos produtos para exportação do Rio de Janeiro (Cavalcanti, 2004). Os estudos da Academia Científica do Rio de Janeiro, fundada em 1772, foram fundamentais nesse projeto de diversificação de culturas. Gêneros como o cacau, o café, o anil e a cochonila se difundiram na colônia graças aos levantamentos e pesquisas produzidos por essa Academia (Pechman, 2002).

Essas medidas fomentistas da segunda metade do XVIII tinham influência da escola fisiocrata e de Adam Smith, e representavam, mais amplamente, para Corcino dos Santos (1980), a finalidade última do governo de aplicação do pacto colonial. Para tanto, havia o amparo da metrópole àqueles que decidissem se aventurar pelas descrição dos produtos comerciados, por cada localidade. 
novidades, através de concessões de privilégios, tais como monopólios, dispensas de taxas alfandegárias e ajuda de custo. Negociações realizadas pelo marquês de Lavradio demonstram a tentativa de cooptar negociantes para seu projeto de diversificação de culturas, como por exemplo através do incentivo real ao cultivo do anil.

Juntamente com o arroz, o anil foi umas das novas culturas que obteve mais êxito no Rio de Janeiro (sem contar a posterior explosão do café, a qual trataremos mais à frente). Em 1784 havia na capitania 284 fábricas de anil, estando 71 situadas nos arrabaldes da cidade do Rio (Lobo, 1978: 41). As remessas de anil do Rio de Janeiro para Lisboa tiveram um aumento na década de 1780, contabilizando 38 arrobas em 1783 enviadas pelo Vice-Rei e 553 arrobas em 1785, apenas dois anos depois ${ }^{57}$. As exportações chegavam a alcançar a Casa da Índia, computando-se o total de 2.500 arrobas de anil em 1785 (soma das remessas reais com a de particulares) (Santos, 1980).

Com os Estados Unidos se tornando independente, e a redução da exportação de arroz da Carolina do Norte, a produção de arroz no Brasil se elevou, assim como a do algodão (que se fixa nas capitanias do norte). Com a proibição, em 1781, pela Coroa, da importação do arroz da Carolina do Norte, a produção interna teve que ser suficiente para alimentar o mercado brasileiro. Além disso, também se exportava bastante arroz: em 1796 a exportação para Portugal atingia 176 mil arrobas (Lobo, 1978: 41).

O açúcar também volta a ganhar importância, e é a partir de meados do século XVIII que a região dos Campos de Goitacases se torna cada vez mais voltada para a produção deste gênero. Pode-se identificar um grande crescimento do número de engenhos no período de 1778 (113 engenhos) a 1819 (400), chegando a 700 engenhos em $1828^{58}$. O escoamento da produção se dava pelo rio Paraíba do Sul até a vila de São João da Paraíba (atual São João da Barra), e então por cabotagem até a cidade do Rio de Janeiro.

A vila de São João da Paraíba, por se localizar numa planície de restinga, com solos pobres, tinha produção agrícola insignificante, mas se caracterizava como porto escoador de toda a produção campista rumo à capital. Esta produção, além do açúcar e

\footnotetext{
${ }^{57}$ Isso sem contar as remessas enviadas por comerciantes particulares. (Santos, 1980: 44, 45).

${ }^{58}$ Dados copilados por Alberto R. Lamego (1945: 76), a partir de José Carneiro da Silva. "Memória Topográfica e Histórica sobre os Campos dos Goitacases", 1819 e Antônio Muniz de Sousa. "Viagens e observações de um brasileiro", 1834.
} 
do aguardente, ainda incluía cabeças de gado bovino e cavalar (apesar da diminuição dessa atividade), assim como alguns gêneros alimentícios como feijão, farinha, milho, arroz e algum algodão -utilizado para a fabricação de tecidos rudes que vestiam escravos (Lamego, 1945).

No distrito de Santo Antônio de Sá do Macacu (atual Japuíba), também houve aumento significativo de 17 engenhos, em 1778, para 48 em 1790, com produção de 36 mil e 40 mil arrobas de açúcar. Havia também, nesta última data, 128 fábricas de anil, produzindo 540 arrobas. Do mesmo modo, o Recôncavo da Guanabara vivenciou um aumento dos engenhos, principalmente nas freguesias de São Gonçalo, Itaboraí, Iguaçu, Irajá, Itaguaí. Ainda, a região de Cabo Frio passou a produzir mais açúcar, se configurando também como grande produtora de anil. (Oliveira, 1986; Santos, 1980)

Em 1797, havia em Cabo Frio 19 engenhos de açúcar, produzindo 337 caixas; 9 engenhocas de aguardente, com produção de 189 pipas; assim como 206 fábricas de anil, alcançando 780 arrobas do produto. Além desses gêneros, também deve-se destacar, nos arredores desta cidade de 23.805 habitantes (sendo 5. 461 escravos), a produção de 78.133 alqueires de farinha de mandioca, além de atividades como o cultivo do arroz, a pesca marinha e a extração de madeira, cujos produtos eram remetidos ao porto do Rio de Janeiro ${ }^{59}$.

Estima-se que em 1799 havia 616 engenhos de açúcar e 406 fábricas de anil na capitania do Rio de Janeiro (Prado Jr., 2000), sendo 228 desses engenhos localizados na cidade do Rio de Janeiro (Falcon \& Mattos, 1972 ). Essa intensificação de formação de lavouras ocupou, em boa parte, sesmarias pertencentes à Cia de Jesus, assim como terras de posseiros. Todos os espaços desocupados ou até então ocupados por posseiros e índios passou a ser motivo de cobiça, incitando a ocupação por parte de negociantes, proprietários e donos de engenho (Oliveira, 1986: 73, 74).

Já entre 1760 e 1762 se deu a entrada na porção sul da colônia das primeiras sementes de café trazidas do Maranhão a mando do desembargador João Alberto Castelo Branco para o Rio de Janeiro. O cultivo da planta se espalhou pela cidade, ganhando os quintais

\footnotetext{
${ }^{59}$ Informações presentes em texto Anônimo. "Memória Histórica da cidade de Cabo Frio". Revista do Instituto Histórico e Geográfico Brasileiro, tomo 46, 1888, p. 223. Apud Santos, 1980: 50.
} 
urbanos e depois se alastrando pelas freguesias rurais. No último quartel do século XVIII o café passa a figurar no ranking dos principais produtos cultivados na capitania do Rio de Janeiro: em 1779 a quantia produzida foi de 57 arrobas, em 1792 de 3.946 arrobas, chegando a 44.399 arrobas em 1806, concedendo ao produto o terceiro lugar dos mais exportados (Cavalcanti, 2004: 86).

A produção de café vai se inserir no movimento citado por Cecília de Salles Oliveira (1986), de busca por novos espaços, pela exploração lucrativa da terra. Neste movimento, há a constituição e o enriquecimento de grupos atacadistas, assim como de proprietários e comerciantes que atuavam na produção de gêneros mercantis e na comercialização de produtos para o mercado interno e externo. Isso geraria uma concorrência com os tradicionais proprietários, donos de muitos escravos e terra, e com os grandes negociantes da praça do Rio de Janeiro.Além disso, os próprios Vice-Reis atuavam na produção local, através da aplicação de capitais e incentivo à diversificação de culturas (Oliveira, 1986: 76).

O cultivo do café acompanha a ocupação das serras da capitania do Rio de Janeiro, muitas até então desconhecidas ou pouco exploradas. Conforme descreve Ilmar Mattos (1994: 70): “desde a cidade do Rio de Janeiro, e em larga medida incentivada pela política joanina, ocorria a expansão dos cafezais. Vencida a barreira da serra, a expansão não tardaria a definir as diretrizes de sua irradiação”.

\subsection{Percursos de "serra-acima"}

$\mathrm{O}$ advento da atividade mineradora nortearia a interiorização da ocupação portuguesa na América. No início da exploração, o caminho paulista, e também o baiano, mais antigos, eram os mais utilizados para se chegar à cobiçada região das minas gerais. Afinal, a descoberta de ouro havia sido feita por iniciativa paulista, com a expedição de Antônio Rodrigues Arzão (1693) e a de Antônio Dias de Oliveira (1698), responsável

pelo descobrimento das minas de Ouro Preto. Em 1704, entretanto, finaliza-se o 
caminho de Garcia Rodrigues Paes, chamado de "Caminho Novo", que saía da cidade do Rio de Janeiro, atravessava o rio Paraíba e seguia adiante até atingir a região.

A vantagem deste caminho na economia de tempo (a viagem levava de doze a dezessete dias, enquanto que, pelo caminho de São Paulo, demorava-se cerca de sessenta dias), levou à sua eleição como caminho oficial, proibindo-se, em 1733, a chegada às Minas por outros meios de comunicação. (Espindola, 2000: 69). Este fato transformou o Rio de Janeiro em principal fornecedor da região e em principal rota de escoamento do ouro.

Para Maria Fernanda Bicalho (2006:1)

A descoberta do ouro inauguraria um novo século e também uma nova fase, constituindo-se em marco fundador de um longo período de prosperidade, multiplicando os sentidos e alargando o raio das rotas percorridas por navios que se faziam ao mar, e comboios que subiam e desciam a serra a partir do e com destino ao Rio de Janeiro.

Com a transferência da capital do Brasil de Salvador para o Rio de Janeiro, realizada em 1763, esta cidade torna-se "chave deste Brasill", nas palavras de D. Luiz Antonio de Souza ao Conde de Oeiras, em discurso de 1765:

pelas notícias e informações de pessoas práticas que incessantemente tenho ouvido desde que desembarquei, e por tudo o que tenho observado, considero hoje o Rio de Janeiro a chave deste Brasil pela sua situação, pela sua capacidade, pela vizinhança que tem com os domínios de Espanha e pela dependência que desta cidade têm as Minas com o interior do país, ficando por este modo sendo [sic] uma das pedras fundamentais em que se afirma a nossa Monarquia e em que [se] segura uma parte muito principal de suas forças e das suas riquezas ${ }^{60}$.

Pode-se dizer que nesse período se inicia a consolidação da centralidade da cidade do Rio de Janeiro no centro-sul do Brasil, processo coroado com a instalação da Corte no Rio de Janeiro. Após este fato, a antiga proibição de abertura de estradas, que já vinha sendo desrespeitada há tempos, é revogada. A partir de então, além de se abrirem novos caminhos, também se oficializaram antigas estradas "proibidas" (Lenharo, 1992: 48). O

\footnotetext{
${ }^{60}$ AHU, Rio de Janeiro, Documentos Avulsos, Cx. 80, doc. 22. Carta de D. Luiz Antonio de Souza ao Conde de Oeiras. Rio de Janeiro, 26 de junho de 1765. (apud Bicalho, 2006: 2)
} 
Caminho Novo, antiga estrada da mineração, teve duas variantes consolidadas: o Caminho do Couto e o Caminho de Terra ${ }^{61}$.

Reforçava-se a necessidade de conectar melhor a chave do Brasil ao restante dos seus domínios. Urgia abastecer a cidade da quantidade necessária de produtos, assim como conectá-la às demais localidades, uma vez que estas não mais deveriam se reportar a Lisboa, através do Atlântico, mas sim ao porto localizado na costa sul do Brasil, fosse por terra ou cabotagem.

Desse modo, coloca-se na ordem do dia a questão da ocupação dos rincões da capitania, através da distribuição de sesmarias, e da construção de estradas e caminhos que garantissem a comunicação. Diferentemente das diretrizes vigentes até o século XVIII, quando evitava-se que os lugares costurassem entre si um contato mais resistente do que aquele com a capital da Metrópole, agora o imperativo era fazer emergir estes lugares desconectados numa amálgama comum, cujo nó se encontrava no Rio de Janeiro.

Refletindo sobre a questão do caminho, Georg Simmel lembra que somente ao homem é dado o poder de ligar as coisas na natureza, ainda mais através de estruturas razoavelmente duráveis, como são as estradas. Segundo ele (1998: 162):

A construção de estradas é de qualquer maneira uma prestação especificamente humana; o animal também não cessa de ultrapassar as distâncias, e muitas vezes da maneira mais hábil e mais complexa, mas ele não liga o começo e o fim do percurso, ele não opera o milagre do caminho: a saber coagular o movimento por uma estrutura sólida, que sai dele.

Para o sociólogo, essa atribuição especificamente humana, de ligar os pontos dispersos, de produzir o espaço através da conexão de lugares, atribuindo-lhes sentidos e funções, pode ser melhor visualizada através da figura da ponte:

É com a construção da ponte que esta prestação atinge seu pico. Aqui parecem se opor à vontade humana de recordação não somente a resistência passiva da exterioridade

\footnotetext{
61 "Uma variante deste percurso [o Caminho Novo] se chamará 'por terra', porque dispensa o trajeto pela baía do Rio de Janeiro até o Porto da Estrela, passará por Iguaçu, onde ataca a serra, unido-se no alto dela ao primeiro caminho referido, no lugar chamado hoje Encruzilhada". (Prado Jr, 2000: 253).
} 
espacial, mas a resistência ativa de uma configuração particular. Ultrapassando o obstáculo, a ponte simboliza a extensão de nossa esfera volitiva no espaço (Simmel, 1998: 162).

A ponte reúne espaços até então desconexos. E tem implicações para ambas as partes ligadas, uma vez que sua conexão se dá de forma horizontal. Se nos atermos às reflexões de Heidegger, podemos concluir que ela confere a uma simples localidade a condição de lugar, uma vez que o lugar só passa a existir a partir da ponte ${ }^{62}$. No caso das sociedades coloniais, a conexão com um centro (a metrópole) dotava os lugares de existência.

No imaginário dos homens ligados à administração havia um entendimento de que sem caminhos e comunicações decentes não se conseguiria levar as "luzes" aos mais distantes rincões. Estrada era, portanto, sinônimo de civilização, pois permitia a chegada aos locais distantes, além de garantir o abastecimento e o escoamento de produtos, gerando riquezas. Paulo Fernandes Viana, ao relatar seus feitos enquanto Intendente da Polícia, declara:

Por fóra da cidade melhorei todas as estradas tanto da banda daquem como dalem d'ella com aterrados e pontes novas e concertos para facilitar a conducção dos viveres, e promover a abundancia na côrte. Tive o gosto de ver Sua Magestade por este meio viajar de carruagem por Maricá, Nuan, São-Gonçalo, Engenho-Novo, Tambi, e depois de fazer a picada com que de Iguassu podesse sua Magestade mesmo ir em sege até o Rio-Preto a entrar na comarca de São-João de Elrei, provincia de Minas Geraes, ajustei esta estrada com todas as pontes precizas e cobertas por 48 contos de reis, a pagamentos de 8 contos de 6 em 6 mezes, para facilitar d'este modo em carros a conducção de frutos d'aquella provincia para esta, e do interior de todas as fazendas, estabelecendo assim um manancial de riquezas para esta côrte ${ }^{63}$.

Segundo Larissa Brown (1986: 223):

\footnotetext{
62 "The location is not already there before the bridge is. Before the bridge stands, there are of course many spots along the stream that can be occupied by something. One of them proves to be a location and does so because of the bridge". Martin Heidegger, Poetry, Language, Thought. Apud Harvey, 2002: 154. 63 “Abreviada demonstração dos trabalhos da Policia em todo o tempo que servio o Dezembargador do Paço Paulo Fernandes Viana”. Revista Trimestral do IHGB, tomo 55, parte I, 1892.
} 
A necessidade de boas estradas se tornou um lugar-comum entre os administradores, e depois de 1808 muitos defenderam a liberação do tráfico e do comércio interno das pesadas taxas e restrições. Tropeiros, dono de ranchos e produtores do mercado interno fizeram pressão por melhorias nas estradas. Entretanto, era difícil reverter décadas de supervisão direta e suspeita sobre o tráfego interno, e apesar de muitas melhorias terem beneficiado o comércio interno, as políticas públicas se voltavam mais às necessidades do setor de exportação.

Maria Beatriz Nizza da Silva (1993: 246) destaca que, a partir de 1808, um número muito maior de pessoas começa a percorrer as estradas antes só transitadas por funcionários públicos enviados pela Coroa portuguesa, ou por naturalistas. A partir de então, "pelas estradas e caminhos do Brasil do fim do período colonial encontravam-se as mais variadas gentes com as mais diversas motivações para se dirigirem de um local a outro, e enfrentando por isso as maiores dificuldades e perigos" (1993: 245). Podiamse classificar essas "mais variadas gentes" (além daquelas que iam de uma fazenda a outra) da seguinte maneira:

- Famílias, que se deslocavam de uma região a outra,

- Negociantes que iam tratar de suas atividades mercantis,

- Bispos que visitavam as suas dioceses ou

- Ouvidores que saíam em correição pela sua Comarca

- Tropeiros que conduziam 'tropas' de mulas ou

- Vaqueiros e suas boiadas

- Capitães do mato que perseguiam escravos fugidos

- Naturalistas que buscavam novas espécies vegetais, animais ou minerais,

Os diferentes viajantes citados acima percorriam também diferentes caminhos, redes que interligavam as regiões. Os tropeiros e vaqueiros transitavam pelos caminhos mais bem estruturados, por onde era possível passar com a tropa. Já os capitães o mato e às vezes os próprios naturalistas circulavam muitas vezes por picadas ou trilhas mais fechadas. Havia ainda os caminhos ocultos do contrabando, verdadeiras rotas paralelas cujo epicentro não era a capital, que podemos chamar "rotas de peregrinação subvertidas" 
Em 1811 é aberta uma ligação inteiramente terrestre entre Minas e os Campos dos Goitacases, possibilitando o abastecimento dessa área canavieira de maneira muito mais rápida do que através da Corte (Prado Jr, 2000: 253). Em 24 de outubro de 1811, a Junta do Comércio inicia suas pesquisas a respeito da construção da Estrada do Comércio. As obras são iniciadas aparentemente em 1812 e terminadas em 1817, deixando pronto um caminho que passava entre Vassouras e Pati do Alferes, servindo o porto conhecido como Comércio, à beira do rio Paraíba (Lenharo, 1992: 49).

A Estrada do Comércio, segundo Caio Prado Jr., "é simbólica da transformação que se operava em Minas Gerais que de mineradora se tornava em agrícola e pastoril; uma zona sobretudo de produção agrária, e como tal que a nova estrada procura pôr em comunicação mais direta e fácil com seu mercado principal que é o Rio de Janeiro" (Prado Jr, 2000: 253).

Saint Hilaire elogia a abertura desta estrada, mas não deixa de comentar sobre o estado de abandono e falta de manutenção em que logo se encontrava qualquer obra na época. Segundo ele, o Caminho do Comércio:

foi aberto em ziguezague, com bastante arte. Construíram-se pequenas pontes para a passagem dos regatos e nos lugares onde os desabamentos são de se temer, as terras foram escoradas. O caminho é muito mais curto que os outros para os habitantes da Comarca de São João e por conseguinte de incontestável utilidade. Trabalhou-se ali, durante muito tempo. Gastaram-se somas consideráveis. Desde porém, que se franqueou a passagem, não só se concluíram as partes apenas esboçadas como não foram conservados os trechos já construídos. As águas já cavaram, ali, profundas covas e trarão a inutilidade desta bela estrada se mais um ano decorrer sem conserva (1974: 18, 19) .

De acordo com Alcir Lenharo (1992), iniciativas privadas haviam antecipado a estrada do Comércio, que recebeu ajuda da Junta do Comércio para sua consolidação. Ao analisar mais de perto os interesses em jogo na construção desta estrada, percebe-se que em torno do vale do Paraíba haviam se estabelecido alguns comerciantes ou membros 
da burocracia reinól, conforme o movimento citado por Lenharo e estudado por Fragoso (1992), na especificidade dos negociantes de grosso trato.

\subsubsection{Entre pontes e desenganos}

A montagem de uma estrutura espacial voltada para o controle e a realização da extração de metais preciosos motivou a formação de núcleos ao longo do caminho da cidade do Rio de Janeiro para as Minas. Paralelamente ao adensamento em torno da Baía de Guanabara, a marcha do povoamento fluminense se dirigiu para o rio Paraíba do Sul, em cujas proximidades formaram-se os povoados de Paraíba do Sul e Campo Alegre (atual Resende), ambos resultantes de um pouso de tropas no caminho para as minas por São Paulo. No trajeto do Rio de Janeiro até esses povoados adensou-se o núcleo de Pati do Alferes, vila em 1820 (Bruno, 1959: 55).

Se desde o final do século XVIII já se identificava uma transformação do capital mercantil de grandes negociantes na montagem de sistemas agrário-escravistas, no período joanino essa tendência se potencializa. Aos esforços de abertura e reforço dos caminhos de interligação da Corte com as áreas produtoras de gêneros exportáveis ou de abastecimento se somava uma política de doação de sesmarias a pessoas de grande “cabedal”. João Luis Fragoso (1992) cita uma série de negociantes de grosso trato que adquiriram sesmarias em diversas porções do território fluminense, não só no vale do Paraíba. Entre os locais mais citados encontram-se: Campos, Cantagalo e Macacu.

Manuel Nogueira da Gama Jacinto, por exemplo, antigo empresário do tesouro português, deputado e escrivão do Real Erário, recebeu enorme quantidade de terras doadas pelo rei, cerca de 12 léguas próximas a Valença, além de terras em São João Marcos (Lenharo, 1992). Além de Jacinto (entitulado Marquês de Baependi, logo depois de ser agraciado como Visconde de Baependi) seu irmão, José Inácio Nogueira da Gama, teria somado, "segundo Taunay, cerca de 17 sesmarias, perto de 20 mil hectares das melhores terras virgens em solo mineiro e fluminense" (Gorestein, 1993: 145) atingindo, assim, a família, grandes extensões de terra. 
A entrada do Marquês de Baependi para a família Carneiro Leão dá uma dimensão de quão estreito era o mundo da elite mercantil fluminense, que concentraria, para além das rentáveis atividades mercantis, vastíssimas extensões de terra e uma infinidade de escravos. Lenharo (1992) ainda chama a atenção para a incorporação de Paulo Fernandes Viana, intendente da Polícia, na família de Carneiro Leão, também através de matrimônio. A articulação de Fernando Carneiro Leão, herdeiro de Brás Carneiro Leão (cuidando de terras próximas a Valença) com Viana e Baependi levaria à construção da Estrada da Polícia, que beneficiaria diretamente as propriedades destes influentes homens. (ver figura 3)

O viajante Saint-Hilaire (1974: 23, 24), percorrendo a capitania do Rio de Janeiro em 1822, faz críticas à concentração de terras no Brasil e dá como exemplo justamente estes ilustres membros da sociedade fluminense:

Retalhou-se o solo pelo sistema das sesmarias, concessões que só se podiam obter depois de muitas formalidades e a propósito das quais era necessário pagar o título expedido. O rico, conhecedor do andamento dos negócios, tinha protetores e podia fazer bons favores; pedia-as para cada membro de sua família e assim alcançava imensa extensão de terras.

$[\ldots]$

Alguns indivíduos faziam dos pedidos de sesmarias verdadeira especulação. Começavam um arroteamento do terreno concedido, plantavam um pouco, construíam uma casinhola, vendiam em seguida a sesmaria, e obtinham outra. O Rei dava terras sem conta nem medida aos homens a quem imaginava dever serviços. Paulo Fernandes Viana viu-se cheio de dons desta natureza. Manuel Jacinto, empregado do tesouro, possui, perto daqui, doze léguas de terra concedidas pelo Rei.

De acordo com Barros (1997: 101), os interrogatórios para concessão de sesmarias eram sempre realizados na cidade do Rio de Janeiro, o que implicava ao:

candidato a sesmeiro ter relações na cidade, ou conseguir trazer as testemunhas de seu local de origem para nela depor. Requerentes que não possuíssem relações na cidade ou que nela não residissem teriam que encontrar meios de convencer suas testemunhas a se deslocarem para lá, uma clara limitação do universo de candidatos de outras áreas frente aos já residentes, que não precisavam enfrentar tal tarefa. 
Figura 3. Propriedades ao redor de Vassouras e Estrada da Polícia (1827) ${ }^{64}$

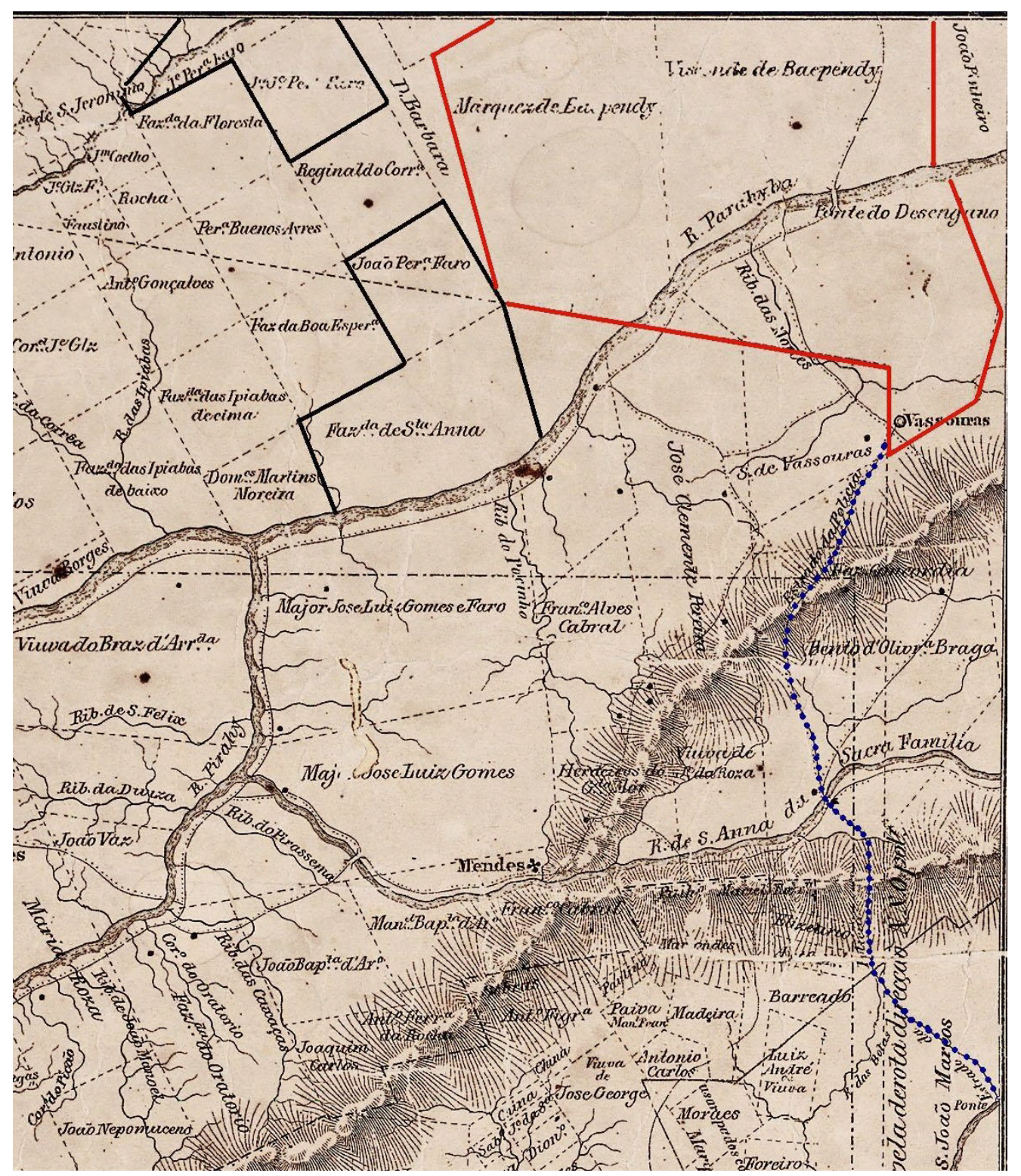

Planta Corographica de uma parte da Província do Rio de Janeiro, 1827.

Arquivo Nacional, Rio de Janeiro, 4Y-MAP50.

${ }^{64}$ Legenda: Estrada da Polícia em azul, propriedades de Joaquim Pereira Faro em preto e de Manuel Jacinto Nogueira da Gama em vermelho. (modificações feitas pela autora). 
Ou seja, além de possuir escravos e renda suficiente para adquirir a sesmaria, os candidatos também deveriam ter relações com a capital, o que demonstra a centralidade que a cidade do Rio de Janeiro, lócus da socialização que gravitava em torno da corte, exercia, com relação à ocupação do interior da capitania. Conforme Andrea Slemian, a urbe fluminense era o "local de obtenção de riqueza e poder" para os negociantes locais (2006: 48), o que significa que é impossível pensar a ocupação do capitania de maneira dissociada da política e das relações que se costuravam no âmbito da Corte.

Em texto clássico de Maria Odila da Silva Dias, os comentários do bibliotecário Luis dos Santos Marrocos sobre o enraizamento dos reinóis na cidade, sobre os quais falaremos no capítulo seguinte, servem como ponte para pensar o enraizamento dos interesses portugueses no restante do território luso-americano - principalmente no centro-sul. Segundo a autora, "Marrocos fornece algumas pistas curiosas sobre o enraizamento dos interesses portugueses no Brasil não só em construções de luxo, mas também e, sobretudo, na compra de terras e no estabelecimento de firmas de negócios" (Dias, 2005: 21).

É justamente sobre esse processo de enraizamento de interesses e formação de uma elite proprietária na capitania do Rio de Janeiro que fala Ilmar Mattos em seu Tempo Saquarema. Para ele, percebe-se claramente "a transformação de burocratas e negociantes em grandes proprietários rurais, a aproximação dos grupos nativos economicamente dominantes da Corte por meio de negócios, a união de famílias proprietárias pela conclusão de alianças matrimoniais, além da nobilitação de todos os que circulavam ao redor da Família Real”. Essa constatação "possibilita perceber como na área polarizada pela cidade do Rio de Janeiro foi-se constituindo o feixe de forças políticas que concretizaria o rompimento com as Cortes em 1822” (Mattos, 1994: 66).

Na visão de João Fragoso e Manolo Florentino (2001), é a partir de uma acumulação que é fruto da proeminência da cidade do Rio de Janeiro como ativo porto comercial que se dá um movimento de ocupação e valorização de novas terras no centro-sul, no antigo esquema da grande propriedade escravista. Isso ocorria, entretanto, de forma 
articulada à existência de propriedades especializadas no abastecimento interno, tanto das fazendas quanto das cidades (Lenharo, 1992).

É principalmente esta região do Vale do Paraíba, e também o sul de Minas que sustentará o Rio de Janeiro como centralidade. Afinal, conforme Raffestin coloca (1980: 20) toda capital, enquanto "ponto-chave" necessita de uma região-chave para dotá-la de centralidade econômica. No caso do Rio de Janeiro, a região econômica que sustentava a capital se fortalece no período joanino, de tal forma que permite a continuidade de uma certa elite no poder e a consolidação de um projeto político.

Ao mesmo tempo, toda centralidade pressupõe uma marginalidade, sendo assim possuidora de um topos e de uma tensão (Raffestin, 1980). Quando elegem-se localidades determinantes no jogo das redes e da centralidade, criam-se também lugares excluídos. Essa eleição, porém, não é definitiva, podendo-se sempre reconfigurar os papéis de centro e periferia. Afinal, "a rede faz e desfaz as prisões do espaço tornado território: ela libera ao mesmo tempo que aprisiona. É por isso que ela é 'instrumento', por excelência, do poder" (Raffestin, 1980: 185).

Temos um caso interessante de monopólio de uma estrutura espacial, na região em questão, com relação à referida Estrada da Polícia. Trata-se de uma ação sofrida pelo Marquês de Baependi e seu vizinho Joaquim Pereira Faro, mobilizada por fazendeiros dos arredores Valença, por terem proibido o acesso dos moradores da região à estrada e ponte sobre o rio Paraíba, que havia sido construída pela Intendência da Polícia, e que se localizava entre a fazenda dos dois ${ }^{65}$. O português imigrado Faro era um homem de grosso trato, "ao mesmo tempo, negociante por atacado de louças e tecidos finos provenientes da Europa e Ásia, sócio da Companhia de Seguros Tranqüilidade, fazendeiro e contratante das miunças e dízimos de açúcar das freguesias de Itaguaí, Nossa Senhora da Conceição e freguesias anexas" (Gorestein, 1993: 151).

\footnotetext{
${ }^{65} \mathrm{Na}$ figura 3 identificam-se as propriedades do Marquês e Visconde de Baependy (em vermelho) e as de João Pereira Faro (em preto). A Estrada da Polícia está ressaltada em azul. É possível que a ponte em questão seja a "Ponte do Desengano", que parece se localizar somente na fazenda do Marquês.
} 
Na comunicação escrita pelos moradores de Valença ${ }^{66}$, contra os dois, lê-se o seguinte desabafo, que indica a privatização do que deveria ser usado por todos:

Possuem aqueles Coronel Faro e filhos, e o dito Márquez [de Baependy] nas margens do Paraíba duas fazendas, por onde passa huma estrada, de que annos ha, estao de posse os moradores, e fazendeiros do predito Curato, que ou abrevia dous dias e meio de caminho aos viandantes, e conductores de tropas com productos de muitas fazendas, nas vizinhanças estabelecidas, ou he permeável ainda mesmo durante o tempo das chuvas, por evitar que se passe tantos atoleiros, ribeiros, e estivas, como ha, na outra, e o atravessar a nado, e em canoas os dous caudalosos rios Paraiba, e Pirahy; ou permitte, que os mesmos moradores, e fazendeiros usem da ponte, e da estrada nova sobre o mesmo Paraiba, construída pela polícia com a despeza da quantiosa soma de Rs. 23:000\$ ponte nova, e estrada, que fica quase privativa daquelles mesmos Potentados, e de seus poucos visinhos.

Perecebe-se que a geografia das redes, materializada nas estradas e pontes, foi também forte aliada na consolidação de laços de interesses entre senhores de terra, comerciantes, burocratas do Reino, ao determinar quem poderia se conectar ou não ao pólo centralizador que era o Rio de Janeiro. Além disso, pensando na centralidade e na marginalidade enquanto dois lados da mesma moeda (sempre determinados em relação ao outro) também se destaca o caso de uma região de fronteira antes marginal, que sofre mudanças na sua condição ao tentar ser incluída no circuito central, sobre a qual falaremos no próximo item.

\subsubsection{Abrindo as portas do sertão: Cantagalo e os Sertões do Macacu}

Se no Vale do Paraíba a rota de escoamento dos metais mineiros havia contribuído para criar pontes entre lugares e impulsionar o desenvolvimento de novas vilas e localidades, outras partes vizinhas sofreram com as proibições de contato e comércio com as Minas. Por exemplo, a capitania do Espírito Santo, no auge da exploração aurífera, foi fadada a um marasmo econômico, pois entre 1704 e 1729 vários documentos demonstravam o impedimento expresso de "passar pela região, fazer entradas, navegar, abrir caminhos e fixar-se como morador" em todo o sertão do Rio Doce, no Espírito Santo (Espindola, 2000:70), sendo todas as vias (fluvial e terrestre) vetadas a qualquer pessoa.

\footnotetext{
66 “Comunicação ao público sobre a questão de uma estrada em Villa de Valença” Na Typografia Imperial de P. Plancher-Seignot. 1828. BNRJ, Obras Raras, 102, 4, 12.
} 
Criavam-se assim os "sertões proibidos", que estabeleciam, indefinidamente, os limites entre as capitanias de Minas Gerais e Espírito Santo, e reuniam a densa mata e os ferozes índios em favor do isolamento da região mineradora. Com tal medida, afastavase o ouro do perigo estrangeiro e ao mesmo tempo buscava-se evitar o extravio e o contrabando (Espindola, 2000: 34).

No caso da capitania do Rio de Janeiro, também contígua a de Minas Gerais, houve proibições quanto às entradas pelos Sertões no noroeste, como forma de evitar os "descaminhos" do ouro. Habitados originalmente pelos índios Puris, Coroados e Botocudos, os sertões do Macacu eram o último reduto desconhecido na capitania do Rio de Janeiro. Inclusive abrigavam, no fim do século XVIII vastíssima floresta nativa de mata atlântica (Gomes, 2004), de cujas bordas se retiravam madeiras para o consumo da capital. O caso deste sertão é emblemático para pensar a política de manutenção das condições hostis como forma de dificultar os contatos entre os lugares. Situado na parte setentrional do Vale do Paraíba, com área de seis mil quilômetros quadrados, os Sertões do rio Macacu fizeram parte de uma estratégia da Coroa em mantê-los como um verdadeiro "fundo territorial", um cinturão natural de mata nativa e índios isolando as adjacências das Minas Gerais.

Entendemos os "fundos territoriais" como as áreas de ocupação pioneira, ou ainda não ocupadas, mas que contêm - potencialmente - uma função para um uso futuro. Para além da vaga qualificação de "sertão", os "fundos territoriais" nos permitem vislumbrar uma estratégia de ocupação territorial protagonizada pela Metrópole. Afinal, na colônia, nem toda a dimensão do território formal sobre o qual o Estado exerce sua soberania era conhecida ou dominada, o que nos leva a fazer uma diferenciação entre o território simplesmente, enquanto jurisdição de um Estado (Alliès, 1980) e o território usado. Este representaria as áreas conhecidas e apropriadas, do ponto de vista da empreitada colonizadora (Santos \& Silveira, 2001; Moraes, 2006). O objetivo da expansão da Coroa, portanto, seria transformar estes fundos territoriais em território usado, na medida em que questões fiscais, produtivas ou de soberania requeressem um maior controle sobre estas áreas (Nogueira, 2008). 
No século XVIII, a partir da interiorização da ocupação que se dá com a mineração, a intenção de controlar a extração dos metais preciosos se soma à inquietação geopolítica, frente ao perigo representado por outras potências ultramarinas. Em resposta, diversas iniciativas visavam o reconhecimento do território luso-brasileiro, para que sua defesa pudesse ser realizada. "Tratava-se, sobretudo, de conhecer o espaço brasileiro com um rigor até então inexistente. Para isso era fundamental definir-lhe os limites" (Almeida, 2006:103).

Dentro dessa perspectiva, a preocupação com a cartografia ganha fôlego, pela necessidade de se demarcarem os novos limites - para além do arbitrário Tratado de Tordesilhas (1492) - que poderiam ser reconhecidos pela extensão da ocupação e do povoamento efetivados até então pelas duas Coroas. Segundo Furtado e Safier (2006: 264):

A imprecisão da posição do meridiano de Tordesilhas, o real povoamento que as duas potências ibéricas estabeleceram no novo mundo e as disputas em torno dessas regiões limítrofes fizeram surgir em Portugal uma corrente de defensores favoráveis a que a demarcação entre as duas potências na América fosse renegociada e refletisse a idéia de uti possidetis, isto é, que cada um mantivesse a posse apenas sobre os territórios que tivessem efetivamente povoado

As negociações diplomáticas que resultaram nos Tratados assinados ao longo do século XVIII despertaram uma "verdadeira febre cartográfica do Brasil, especialmente do interior e da região do rio da Prata, que municiasse os seus representantes diplomáticos com informações precisas sobre as regiões em disputa" (Furtado \& Safier, 2006:265). Para se garantir a hegemonia sobre os vastos territórios da América, buscava-se dominar as regiões limítrofes, ainda que existisse uma série de "vazios" ocupacionais entre regiões contíguas. Estes "vazios", que "até então, apareciam frequentemente nos mapas como áreas em branco, grandes vazios cartográficos" (Furtado \& Safier, 2006: 270) eram qualificados, em geral, como "sertão".

Em 1729. D. João V determina o envio do jesuíta italiano Domenico Capasso e do português Diogo Soares, ambos matemáticos, ao Brasil, com a clara determinação de conhecer e descrever os seus sertões, assim como de "dar forma aos limites entre as diferentes capitanias ('governos') e bispados do Brasil, e à própria divisão entre os 
Estados do Brasil e do Maranhão" (Almeida, 2006:104). O resultado do trabalho dos jesuítas se faria em forma de inúmeras cartas geográficas.

De acordo com a Provisão régia de 18 de novembro de 1729, os jesuítas deveriam seguir as seguintes instruções:

Dareis princípio a esta obra pelo Rio de Janeiro, caminhando para a parte que vos parecer mais util para o meu serviço, porque convem muito que se fação mapas o mais que for possível dos vastos certões do mesmo Estado, especialmente nos das Minas, que novamente se descobrirão para as partes da Capitania do Espírito Santo ${ }^{67}$.

Percebe-se, pelas tarefas dadas aos jesuítas matemáticos, que o foco das atenções se voltava para a parte meridional do Brasil, demonstrando a mudança do eixo norteador da América portuguesa para o centro-sul, por motivos tanto geopolíticos quanto econômicos. É nesse processo que o porto do Rio de Janeiro ganha mais proeminência, marcando o início da construção de uma centralidade que seria coroada no século XIX, com a vinda da corte portuguesa para o Brasil.

Em mapa pouco detalhado, feito pelo jesuíta italiano Domenico Capasso, de cerca de 1730, não há qualquer indício de ocupação na região dos Sertões do Macacu. Na verdade, quase é possível afirmar que não há sequer o registro dessa porção da capitania do Rio de Janeiro, pois a enorme distância entre a serra de Bacaxá e o rio Paraíba, onde poderíamos localizar os Sertões do Macacu, é diminuída, dando a impressão de ser incrivelmente menor. (figura 4). Além disso, as cartas sertanistas realizadas pelo companheiro de Capasso, o também jesuíta matemático Diogo Soares, tampouco tratam destes sertões, se fixando nos sertões dos rios mineiros, como das Velhas e São Francisco e na Serra da Mantiqueira, no triângulo formado pelo encontro das capitanias de São Paulo, Minas Gerais e Rio de Janeiro.

${ }^{67}$ Provisão Régia de 18 de novembro de 1729. Arquivo Histórico Ultramarino (AHU), cód. 248, fls 249v.250. (apud Cortesão, 1965: 215) 
Figura 4. Mapa Corographico da Capitania do Rio de Janeiro

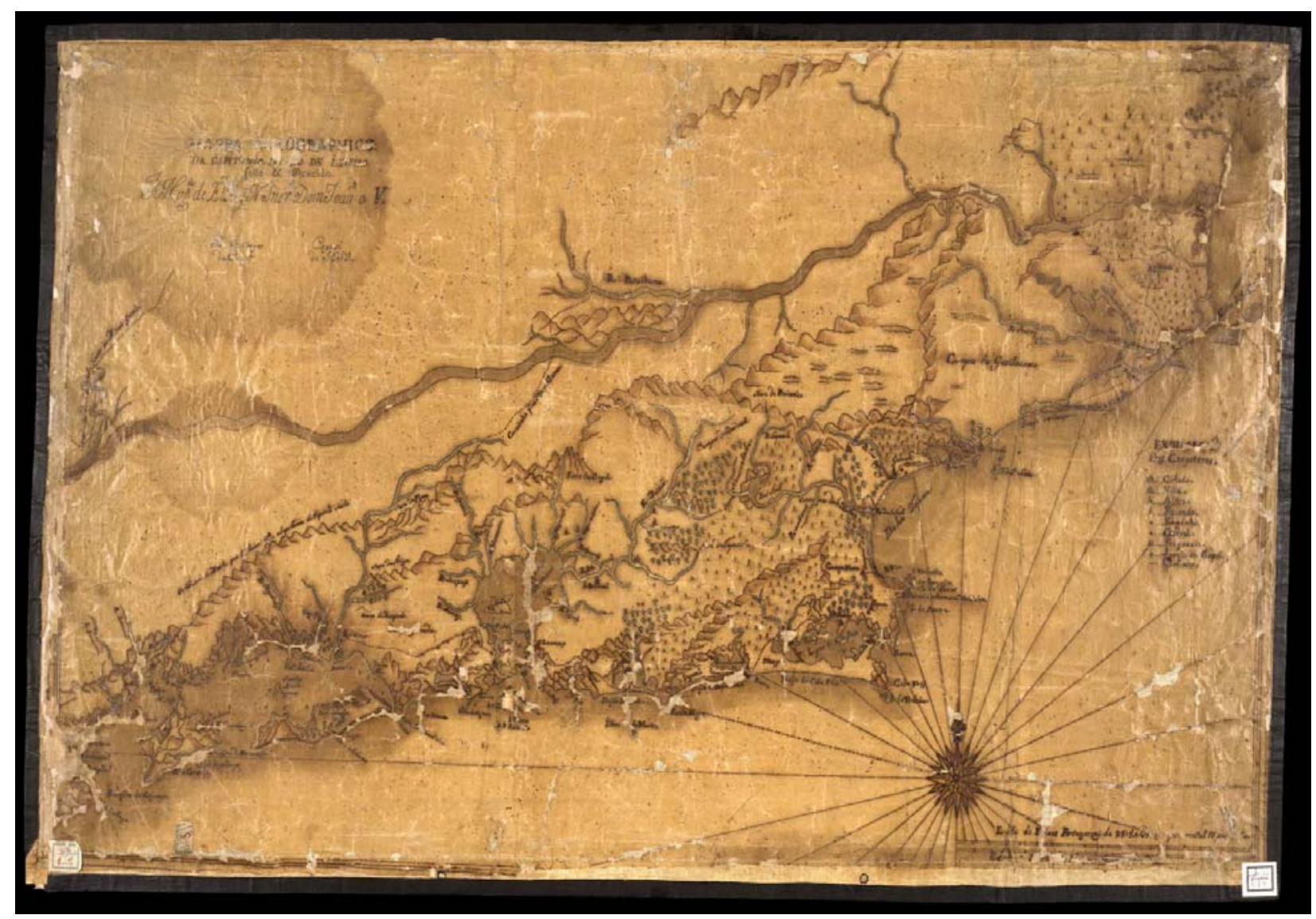

Capasso, Domenico (c. 1730). "Mapa Corographico da Capitania do Rio de Janeiro", manuscrito. Mapoteca da BNRJ, ARC 023,01,001. (Catálogo Digital: referência cart542711.tif) 
Já na década de 1760, todavia, as atenções do governo português voltam-se completamente aos Sertões do Macacu. Quando Mauricio Portugal, morador das Cachoeiras do Macacu, depois de encontrar ouro na região de "serra acima", pede autorização para abrir um garimpo nas áreas proibidas, o Vice-Rei Conde da Cunha (1763-1767) decide concedê-la, mas logo revoga a autorização, mandando "fechar aqueles sertões e destruir todas as fazendas e ranchos situados no sopé da Serra do Mar, inclusive a moradia de Mauricio Portugal” (Garcia, 1995: 180, 181).

Para acompanhar esta ordem, é erguido o Registro de Entrada do Mato, que de certo modo restringiu os fluminenses de avançar a serra, mas não barrou o possível acesso pelas Minas Gerais. Mesmo com essas medidas, contudo, nas cartas do capitão Mor da Vila de Macacu nota-se que o efeito obtido foi o contrário:

comensarão a entrar nele [naquele Sertão] ocultamente, alguns sertanejos para o explorar, [entre eles] muitos mineiros, e gente armada, e penetrando aqueles matos, se forão estabelecer em huma aldeia de índios, onde fizerão plantaçoens de milho, feijão e outros viveres sendo os constam-te que dali se extrahião copiozisimo cabedal ${ }^{68}$.

Apesar da proibição real, algumas levas de migrantes, no final da década de 1770, se instalam nos sertões do Macacu, nas Minas do Novo Descoberto, atual cidade de Cantagalo, em função do garimpo clandestino fundado pelo natural de Minas Gerais Manoel Henriques, conhecido como Mão de Luva. Segundo Garcia (1995: 106), a atuação do bando do Mão de Luva se espraiava por toda a região leste fluminense, pelo sul da Capitania do Espírito Santo, interligando as vilas de Vitória, São Salvador dos Campos dos Goitacazes e Santa Helena do Cabo Frio e os povoados de Barra do Itabapoana, Barra do Itapemirim, Barra de São João, São João da Barra, Macaé e Aldeia de São Pedro. Além deste eixo, havia comunicação dos garimpeiros de Cantagalo também com o sul das Minas Gerais e com a própria Baía de Guanabara.

Com isso, monta-se uma estrutura de caminhos, vendas e pousadas para abastecer os garimpeiros, numa espécie de povoamento paralelo àquele controlado pela Coroa. A partir dos ancoradouros clandestinos da costa fluminense era possível também ter contato com o comércio Atlântico.

\footnotetext{
${ }^{68}$ Cartas do Capitão Mor da Vila de Macacu, BNRJ, cód. 9, 3, 17, n. 20 e Correspondencia oficial com a Corte, BNRJ, 28, 28, 4. (apud Garcia, 1995).
} 
Paralelamente à construção desta estrutura material clandestina, a produção cartográfica da época sobre a capitania do Rio de Janeiro passou a retratar a região dos sertões do Macacu como um imenso vazio, e ainda com o seguinte qualificativo: como "sertão" ocupado por "índios bravos" ou "selvagens", como nos mapas feitos por Manoel Vieira Leão $^{69}$ (1767) e por Francisco Roscio ${ }^{70}$ (1777).

Pela ordem do Vice-Rei conde da Cunha, Vieira Leão realizou a famosa Carta Topográfica da Capitania do Rio de Janeiro, em 16 folhas, que retrata com detalhe as freguesias, vilas, cidades, engenhos e caminhos da dita capitania. (figura 5)

Chama a atenção, contudo, a maneira com que Vieira Leão representa os antes ignorados Sertões do Macacu, fazendo saltar aos olhos a enorme extensão da área, toda contígua à Capitania de Minas Gerais, classificada como "Certão (ou sertão) ocupado por índios bravos". (encontram-se as duas grafias no mesmo mapa). Próximo ao rio Macacu lê-se também a seguinte inscrição: "fazendas q se demolirão" (detalhe, figura 6), o que nos remete imediatamente à história de Mauricio Portugal, que teve suas fazendas demolidas ao tentar pedir autorização para adentrar os sertões e garimpar o ouro de aluvião encontrado. Sendo o mapa publicado pouco tempo depois do incidente, em que se decidiu vetar qualquer entrada nos sertões do Macacu, pode-se especular que a decisão de qualificar este sertão como hostil, ainda registrando uma ação repressora do governo em relação à sua ocupação, seria uma tentativa deliberada de espantar novos visitantes na região.

É a partir do mapa de Manoel Vieira Leão, que o sargento-mor de engenheiros Francisco Roscio realizaria uma nova carta da capitania do Rio de Janeiro, em 1777, dez anos depois da primeira.

\footnotetext{
${ }^{69}$ Em 1751, aporta no Brasil o militar, astrônomo e topógrafo português Manoel Vieira Leão, como integrante de uma comissão técnica que tinha por objetivo demarcar os limites do Brasil meridional, a partir do Tratado de Madri (1750). Como boa parte dos cartógrafos que prestaram serviços à Coroa na confecção de mapas na escala continental, Leão também foi convidado por governadores de capitania a produzir cartas regionais (Adonias, 1993: 396).

${ }^{70}$ Roscio havia chegado de Portugal em 1769, na qualidade de capitão da Infantaria, para servir no Rio de Janeiro sob ordens do brigadeiro Jacques Funck. Assim como Vieira Leão, veio para integrar uma comissão responsável pela demarcação meridional de um Tratado (agora não mais o de Madri, mas sim o de Santo Idelfonso).
} 
Figura 5. Carta Topographica da Capitania do Rio de Janeiro - folha 4

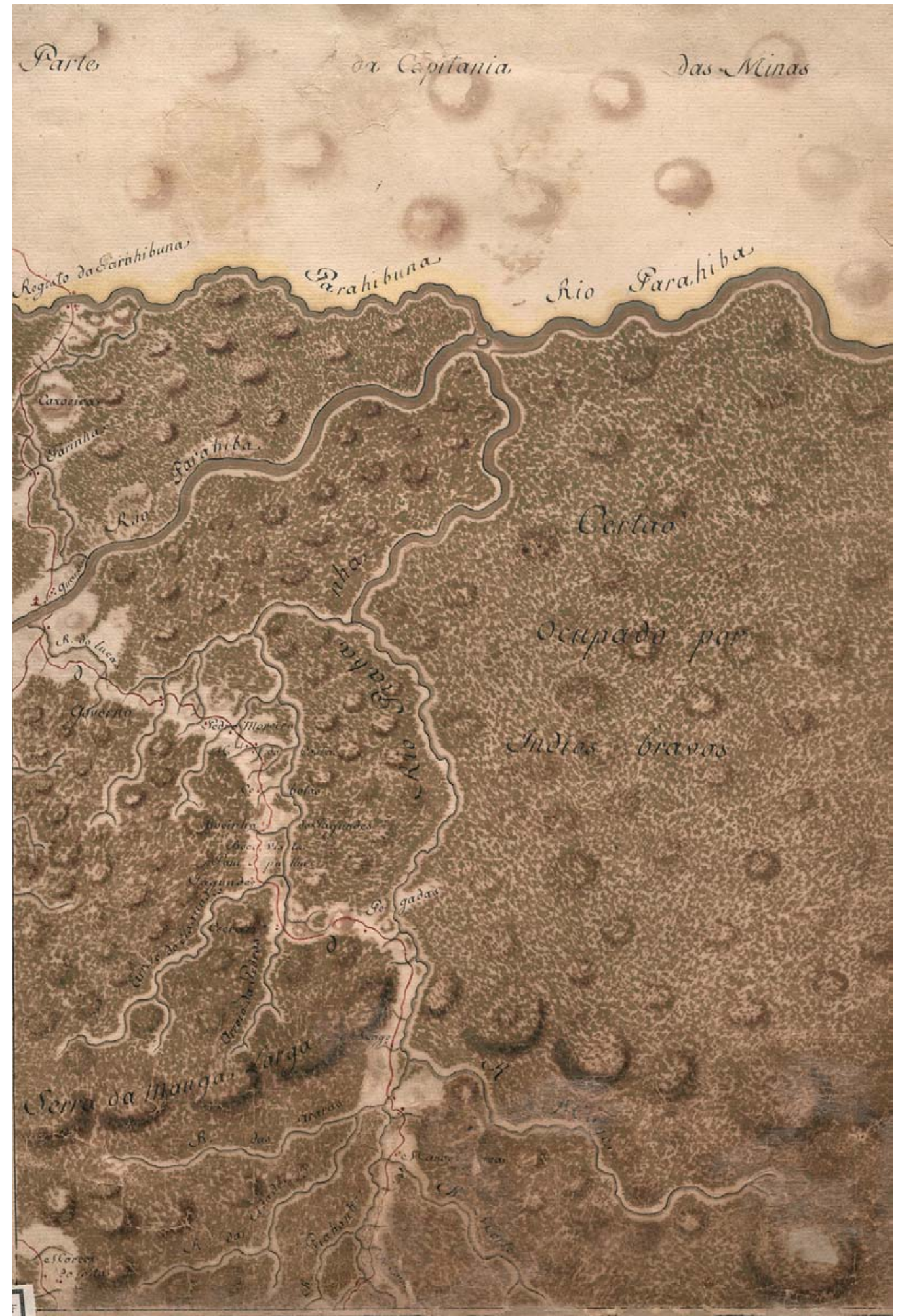

Leão, Manuel Vieira (1767). "Cartas topographicas da capitania do Rio de Janeiro mandadas tirar pelo Illmo. e Exmo. Sr. Conde da Cunha Capitam general e Vice-Rey do Estado do Brazil", folha 4, manuscrito. Mapoteca da BNRJ, CAM.02,008 (Catalogo digital: referência cart512339) 
Figura 6. Fazendas que se demoliram (detalhe da Carta Topographica da Capitania do Rio de Janeiro)

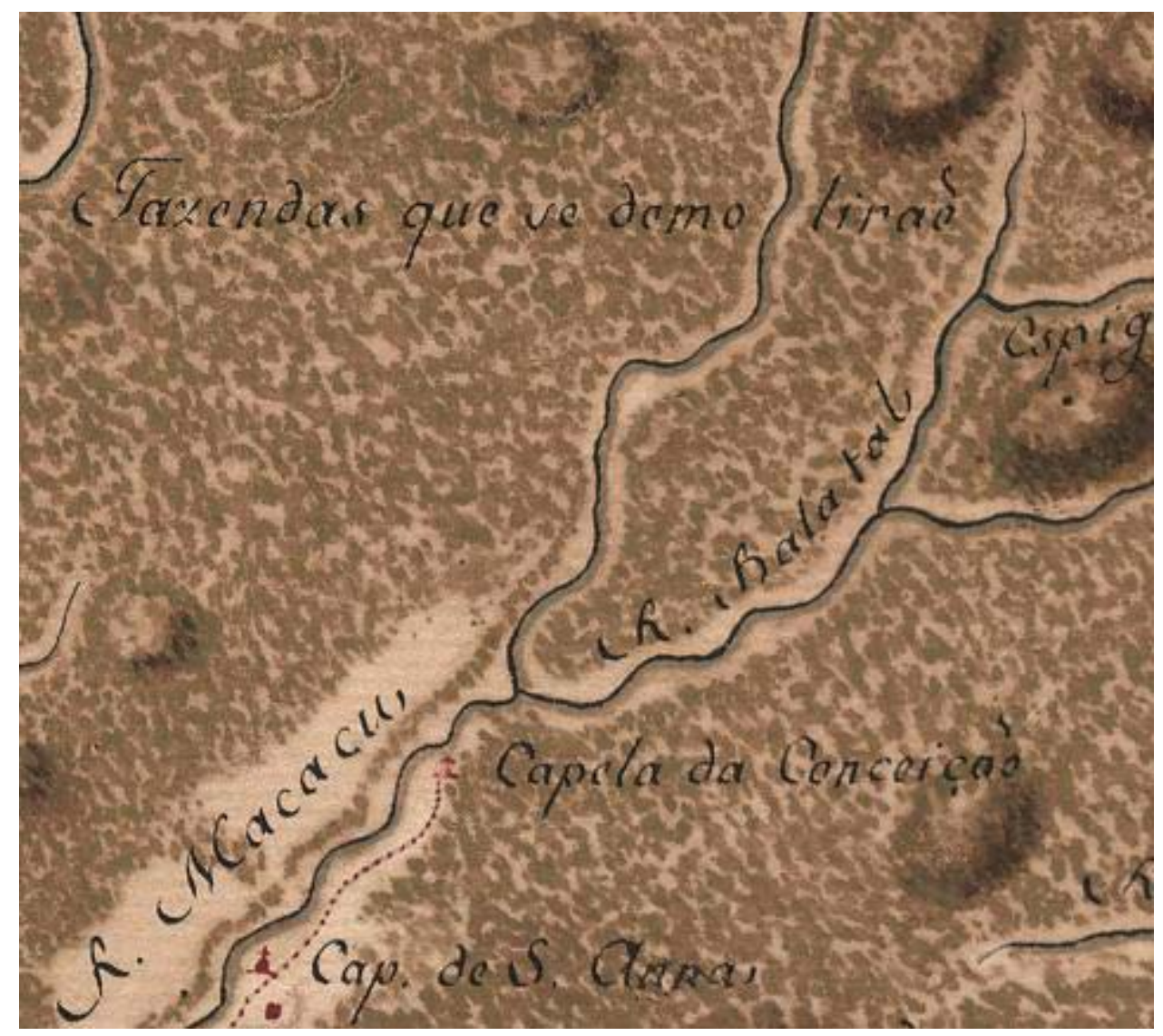

Leão, Manuel Vieira (1767). “Cartas topographicas da capitania do Rio de Janeiro mandadas tirar pelo Illmo. e Exmo. Sr. Conde da Cunha Capitam general e Vice-Rey do Estado do Brazil", folha 7, manuscrito. Mapoteca da BNRJ, CAM.02,008 (Catalogo digital: referência cart512339) 
No mapa de Roscio, a Carta Corographica da capitania do Rio de Janeiro (figura 7), ao invés de "Certão ocupado por índios bravos", lê-se agora a seguinte frase: "Certão pouco conhecido, montuozo, emboscado e ocupado por varias nascoens de índios salvagens" (ou seja, "sertão pouco conhecido, montanhoso, emboscado e ocupado por várias nações de índios selvagens”). Os “índios bravos” de Vieira Leão viram selvagens, além disso, reforça-se a situação de desconhecimento de tal sertão e adicionam-se informações sobre o relevo montanhoso (também hostil) e emboscado (talvez também pelas matas fechadas). Nele também consta a referência das fazendas demolidas e basicamente as mesmas informações do mapa de Vieira Leão, com alguns acréscimos. Fora o espaço vazio do sertão, o mapa é bastante detalhado e acurado ${ }^{71}$.

É possível afirmar que, a partir dos dois mapas mencionados, cria-se uma ideologia geográfica (Moraes, 1988) em relação ao Sertão do Macacu, como local "inculto", incivilizado, pois habitado por índios bravos e selvagens. De maneira sutil, ao classificar desse modo tal região, justifica-se qualquer projeto futuro de ocupação, já que a função da Coroa seria levar as luzes da civilização aos mais remotos rincões. Ainda, ao se omitir o fato de que havia ouro de aluvião no local, se pretendia manter os aventureiros, contrabandistas e faiscadores a uma considerável distância. Afinal, podemos concordar com Harley que, "ao tempo que o mapa nunca é a realidade, de certa maneira contribui a criar uma realidade diferente" (2005:206).

O "sertão", na definição de Antonio Carlos Robert Moraes, "não é um lugar, mas sim uma condição atribuída a vários e diferentes lugares" (2003: 47). Segundo o viajante francês Auguste Saint-Hilaire, escrevendo no início do século XIX, o sertão definia-se da seguinte maneira: "O nome de Sertão ou Deserto não designa uma divisão política de território; não indica senão uma espécie de divisão vaga e convencional determinada pela natureza particular do território e, principalmente, pela escassez de população" (Saint-Hilaire, 2000: 307).

${ }^{71}$ O Vice-Rei Marques do Lavradio acreditava ser Francisco Roscio: "talvês o único em tôda esta capitania de quem se possam acreditar as Cartas e Plantas que êle tem feito porque não póe em Papel senão o que êle viu, mediu e examinou, o que todos os outros fazem pelo contrário, riscando a maior parte das vezes por estimação ou informação; e este oficial é o mais capaz que eu cá considero para tirar uma carta exacta de tôda esta Capitania, da de Santa Catarina, da do Rio Grande e da de São Paulo".

Ofício do Marquês do Lavradio para Martinho de Melo e Castro. Rio de Janeiro, 21/6/1776. AHU Rio. de Janeiro, Cx. 100, D. 8585. (apud Viterbo, 1988, vol.II: 483). 
Figura 7. Carta Corographica da Capitania do Rio de Janeiro
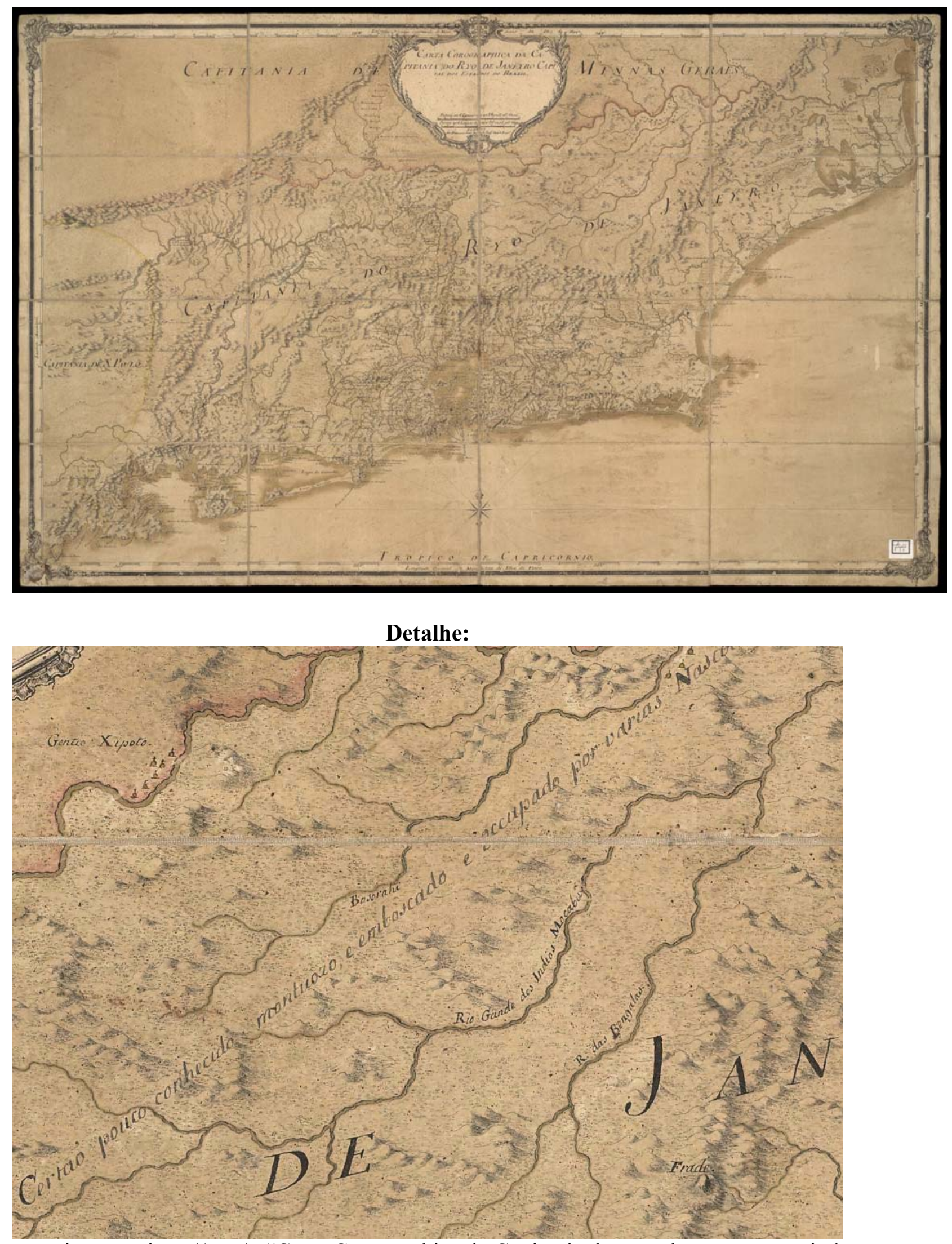

Roscio, Francisco (1777). "Carta Corographica da Capitania do Ryo de Janeyro, capital dos Estados do Brasil”, manuscrito. BNRJ, ARC.012,04,006. (catalogo digital: cart534317.tif) 
Podemos dizer, desse modo, que o sertão é, no território colonial, o espaço vazio de população (ou melhor, de população dita civilizada), que, como um deserto, cria uma fronteira interna entre os lugares conhecidos e as "terras de ninguém". O sertão é, enfim, o espaço das "gentes bárbaras", o lugar do outro. Na lógica da colonização, entretanto, que pressupõe o crescimento "em sentido horizontal", ou seja, "na incorporação de novas fronteiras" (Fernandes, 1977: 25) este espaço ainda desconhecido figurava nos projetos da Metrópole enquanto um território potencialmente incorporável. Melhor explicitando:

Definir um lugar como sertão significa, portanto, projetar sua futura valorização dentro de moldes diferentes aos ali vigentes no momento da ação. Nesse sentido, pode-se dizer que os lugares se convertem em "sertões" ao atrair o interesse de agentes sociais que buscam estabelecer novas formas de ocupação e exploração naquelas paragens. [...] O sertão é comumente percebido como um espaço para a expansão, como o objeto de um movimento expansivo que busca incorporar o novo espaço, assim denominado, aos fluxos econômicos ou a uma órbita de poder à qual escapa nesse momento. (Moraes, 2003: 48, 49)

A fronteira é tanto uma representação quanto uma coisa em si (pois ela tem materialidade e causa constrangimentos reais). Ela pode ser tanto uma fronteira-zonal (Raffestin, 1980), quanto uma linha rígida, um limite ${ }^{72}$, mas em ambos os casos sua construção implica na imaginação da existência e da ameaça do "outro" (Van Houtum \& Strüver, 2002: 142). No já citado texto de Georg Simmel sobre pontes e portas (1998: 164), a reflexão realizada sobre a imagem da porta nos ajuda a entender a dimensão dupla da fronteira: de possibilitar tanto a abertura quanto o fechamento. A porta pode se abrir e estabelecer uma ligação entre o espaço do homem e tudo aquilo que está fora dele, gerando a possibilidade de uma troca durável. Mas ela também pode se fechar, o que implica num sentimento forte de bloqueio.

Diferentemente da ponte, que implica numa ligação horizontal, que coloca dois lugares em relação (ainda que um possa exercer dominação sobre o outro), a porta é construída

\footnotetext{
${ }^{72}$ Uma discussão sobre as diferenças entre fronteira e limite pode ser encontrada em Nogueira, 2008.
} 
para permitir tanto a incorporação do mundo exterior quanto sua exclusão. Ou seja, ela permite que se filtre o que deve entrar ou não em determinando espaço.

No caso dos sertões, a construção de uma fronteira imaginária entre os locais civilizados e os rincões bárbaros, que não deveriam ser penetrados, implicava no fechamento de determinada área da sua conexão com o resto do mundo. Mas a partir do momento em que não faz mais sentido insistir neste encerramento e que, pelo contrário, se deseja expandir a fronteira das áreas povoadas e produtivas, começam-se a abrir as portas dos sertões.

Durante a segunda metade do século XVIII, a partir do governo pombalino (17501777), uma série de reformas é implementada, tendo como foco garantir a manutenção do território e sua expansão. Demarcações espaciais da hegemonia portuguesa nas fronteiras e povoamento dos territórios pouco ocupados, ou aldeamento de tribos indígenas aparecem como medidas fundamentais. Tratava-se de converter os sertões (fundos territoriais) em território usado.

Para Maria Fernanda Bicalho (2006:20):

No que diz respeito especificamente ao Rio de Janeiro, a política de povoamento e fundação de vilas se impôs e se aprofundou durante toda a segunda metade do século XVIII, perpassando as instruções dirigidas ao Marquês de Lavradio, o seu relatório ao entregar o governo a Luís de Vasconcelos e Sousa, e as instruções dadas a este vice-rei pelo Secretário Martinho de Mello e Castro, em 1779.

É no governo do vice-rei Luis de Vasconcelos e Sousa (1779-1790) que se realiza a descoberta e o combate do garimpo clandestino comandado pelo "Mão de Luva". Em 1785, envia-se uma tropa orientada a destruir o garimpo, que assim o logra fazer, conforme relata o próprio vice-rei, em oficio ao Secretário Martinho de Mello e Castro:

Havendo S. M. mandado evacuar, pela tropa de Minas Geraes; aquelle vasto sertão, que se achava ocupado por um grande número de contrabandistas, que se tinham aproveitado das suas riquezas, formando nos sítios que lhes pareciam mais commodos as suas habitações e lavras, para poderem melhor continuar as suas escandalosas 
usurpações, resultou d'aquella diligencia, que foi igualmente auxiliada de parte d'esta Capitania, aprehenderem-se os facinorosos, que ali se encontraram com seu famoso cabeça, o celebre Manoel Henriques, por alcunha o -Mão de Luva-, os quaes foram presos e sentenciados no juízo da Intendência geral do ouro d'esta cidade. (Revista do IHGB, 1842:25).

A Coroa impõe assim seu domínio efetivo sobre aquele "sertão", tentando se colocar na direção da atividade mineradora e, para isso, concedendo um grande número de sesmarias na região. Conforme Vascocelos, os objetivos da Coroa portuguesa eram: "povoar-se aquelle inculto sertão por vassallos uteis e industriosos, reprimir-se a continuação dos extravios e contrabandos, e repartirem-se as terras mineraes por pessoas que, empregando-se n'aquelles trabalhos, pudessem aproveitar-se d'elles em utilidade do Estado" [grifo nosso]. Para tanto: "abriram-se estradas para o novo arraial do Cantagallo, que era o sitio que se achava descoberto e frequentado pelos ditos conntrabandistas: estebeleceu-se nelle uma casa de Registo do ouro, com os officiaes precisos", e também, se realizou a distribuição de sesmarias e datas de mineração aos “vassalos d'El Rei”, ou seja, "pessoas inteligentes” e de cabedal (Revista do IHGB, 1842: 25).

Com a fama de que havia muitos metais preciosos a explorar na região, apareceram diversos pretendentes às datas e sesmarias, mais do que o esperado. $\mathrm{O}$ critério de distribuição se resumia basicamente "segundo o número de escravos que apresentavam" (Revista do IHGB, 1842:26). Na publicação de Portaria convocando os interessados a adquirirem alguma das concessões de Sua Majestade no local, lia-se que a noticia deveria chegar a todos, e quem quisesse comerciar gado ou outras provisões no local também seria bem vindo (ANRJ, códice 53, vol 16,fl. 141, 1786).

Desse modo, abriam-se as portas do sertão, fazendo cair por terra a proibição de sua ocupação. Pelo contrário, a partir do controle pela Coroa fazia-se necessária a cooperação de diversas pessoas com "a força da indústria e do trabalho" para povoá-lo. Mas a utilização de qualquer caminho que não o oficial reforçado pela Coroa, onde se localizariam os registros, seria punida, pois era "inteiramente vedada e prohibida outra deferente entrada e comonicação debaixo das penas de serem reputados [os seus usuários] desde logo por contrabandistas". (ANRJ, códice 73, vol. 16, fl.140, 1786). 
A extração de ouro, apesar do frenesi dos requerentes de sesmarias e datas, não teve vida longa, pois os garimpeiros clandestinos haviam esgotado quase todas as possibilidades de exploração. O mineralogista inglês John Mawe, talvez o primeiro viajante que se aventura pelas bandas de Cantagalo (segundo ele, recanto "dos últimos explorados nesta região do Brasil”), após a conquista do sertão, relata o seguinte:

o governo, tornando-se assim senhor do território, imaginou encontrar aí tanto ouro quanto aí se estabeleceram os primeiros garimpeiros e publicou muitos regulamentos injustos, oprimiu os nativos como jamais se vira, instalou registros em vários pontos, para impedir o contrabando, e encheu toda a redondeza de guardas. Os numerosos colonos, atraídos pela suposta riqueza do lugar, não tardaram a verificar que o creme fora extraído pelos contrabandistas, e pouco a pouco voltaram a atenção para a agricultura, que lhes assegurava existência menos precária que a mineração (Mawe, 1978: 98)

Mawe percorreu o caminho entre a cidade do Rio de Janeiro e a região de Cantagalo em 1809, o qual detalha também em mapa (figura 8). Descrito como muito sinuoso, o caminho, melhorado por iniciativa da Coroa, possivelmente era um resquício do trajeto dos contrabandistas. No mapa, publicado em seu livro Travels in the interior of Brazil, de 1816, percebe-se que em pouco tempo a presença da administração metropolitana se fez mostrar naquele "sertão", através da normatização do espaço, com a instalação de registros e a tomada de controle da atividade mineradora. Percebe-se também o avanço do povoamento em direção à Vila de S. Pedro de Cantagallo (elevada em 1814).

Para Barros (1997: 88), “a abertura dessa nova fronteira alterou todas as proporções entre as frentes de expansão anteriores". A região de Cantagalo "sozinha passou a receber $1 / 4$ de todos os pedidos de sesmarias entre 1779 e 1808 ". "No vale do Rio Grande implantaram-se diversas sesmarias nas décadas de 1780 e 1790, inclusive aquelas que iriam formar a fazenda Morro Queimado, onde se implantaria a colônia suíça de Nova Friburgo" (Erthal, 2006, s/pág) 
Figura 8. O caminho para Cantagalo

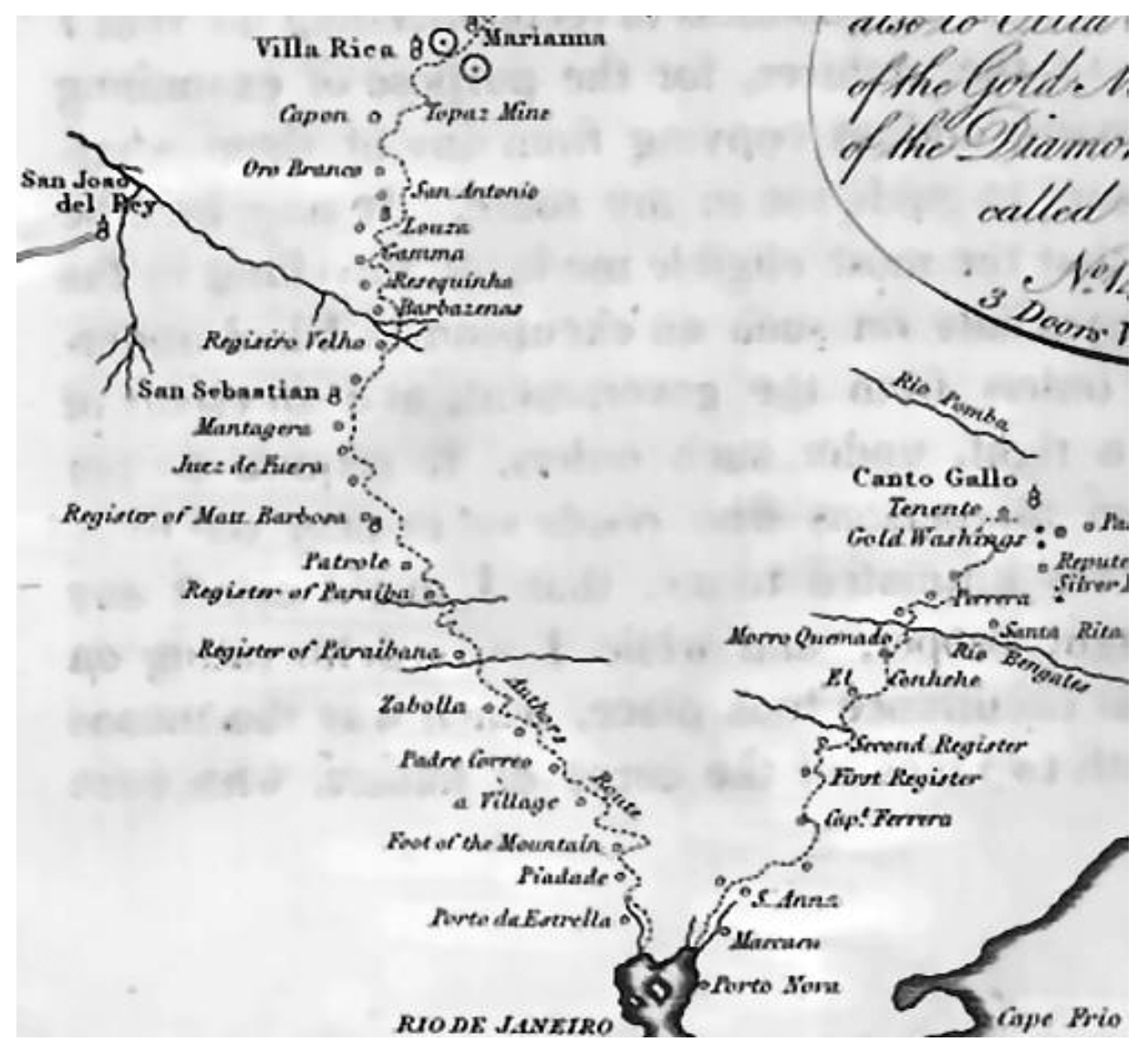

Mawe, John (1812). "Travels in the Interior of Brazil, particularly in the Gold and Diamond Districts of that country by Authority of the Prince Regent of Portugal, including a voyage to the Rio de la Plata, and an Historical Sketch of the Revolution of Buenos Ayres". Londres. Mapoteca da BNL, Portugal (catálogo digital, n. 263) 
Entre os que adquiriram estas sesmarias, encontram-se alguns dos negociantes mais ricos da capital, como Brás Carneiro Leão. Apenas dois anos após a destruição do velho garimpo, Carneiro Leão obteve propriedades em Novas Minas do Macacu, e, depois, em 1789, "requereu da Coroa terras no novo descoberto do sertão de Cantagalo, sendo atendido com a doação de meia légua em quadra" (Gorestein, 1993: 198). Pelo mapa de 1819, intitulado "Reconhecimento do rio de Macacu e da estrada que conduz a Nova Friburgo", registra-se que Carneiro Leão possuía uma fazenda próxima à vila de Macacu e ao Porto das Caixas (figura 9).

Outros comerciantes também receberam sesmarias em Cantagalo, que, conforme bem disse Mawe, duraria pouco como mineradora, logo se transformando em região exportadora de café. Para Erthal, "se a atividade mineira colocou Cantagalo no mapa fluminense e brasileiro, a economia cafeeira foi o fator principal da efetiva ocupação da região e, indubitavelmente, projetou a região até no exterior” (2006, s/ pág).

No caminho entre a capital e a vila de Cantagalo, na localidade chamada Morro Queimado, ergueu-se um empreendimento de imigração (não portuguesa) organizado e patrocinado pela Coroa, iniciativa levada a cabo por Paulo Fernandes Viana ${ }^{73}$. Assim, em 1818, cria-se a Freguesia de São João Batista de Nova Friburgo, com a vinda de 261 famílias (num total de 2.006 pessoas) do cantão suiço de Freibourg, principalmente, mas também de outros cantões franceses e alemães. Depois, em 1824, se juntariam a estas famílias, mais 342 imigrantes alemães (Erthal, 2006).

A intenção do empreendimento seria a de "ocupar lugares distantes e estratégicos, mas demograficamente desocupados ou, então, não ocupados por 'indivíduos civilizados' e súditos do rei fidelíssimo que, para os portugueses do século das Luzes, eram os únicos garantes da propagação da 'civilização', 'da religião e da fé”' (Domingues, 2007: 124). Para tanto, o Príncipe Regente concedia terras, casas, instrumentos agrícolas, sementes e gado, além de mesadas nos primeiros dois meses e isenção de expostos (exceto do quinto).

\footnotetext{
${ }^{73}$ Este empreendimento pioneiro só havia sido precedido pela mobilização de imigrantes suecos para trabalharem na Fábrica de ferro de Ipanema, em Sorocaba, em 1810, além das "remessas" de imigrantes portugueses dos Açores. (Domingues, 2007).
} 
Figura 9. Fazenda de "Braz Carneiro" (detalhe)

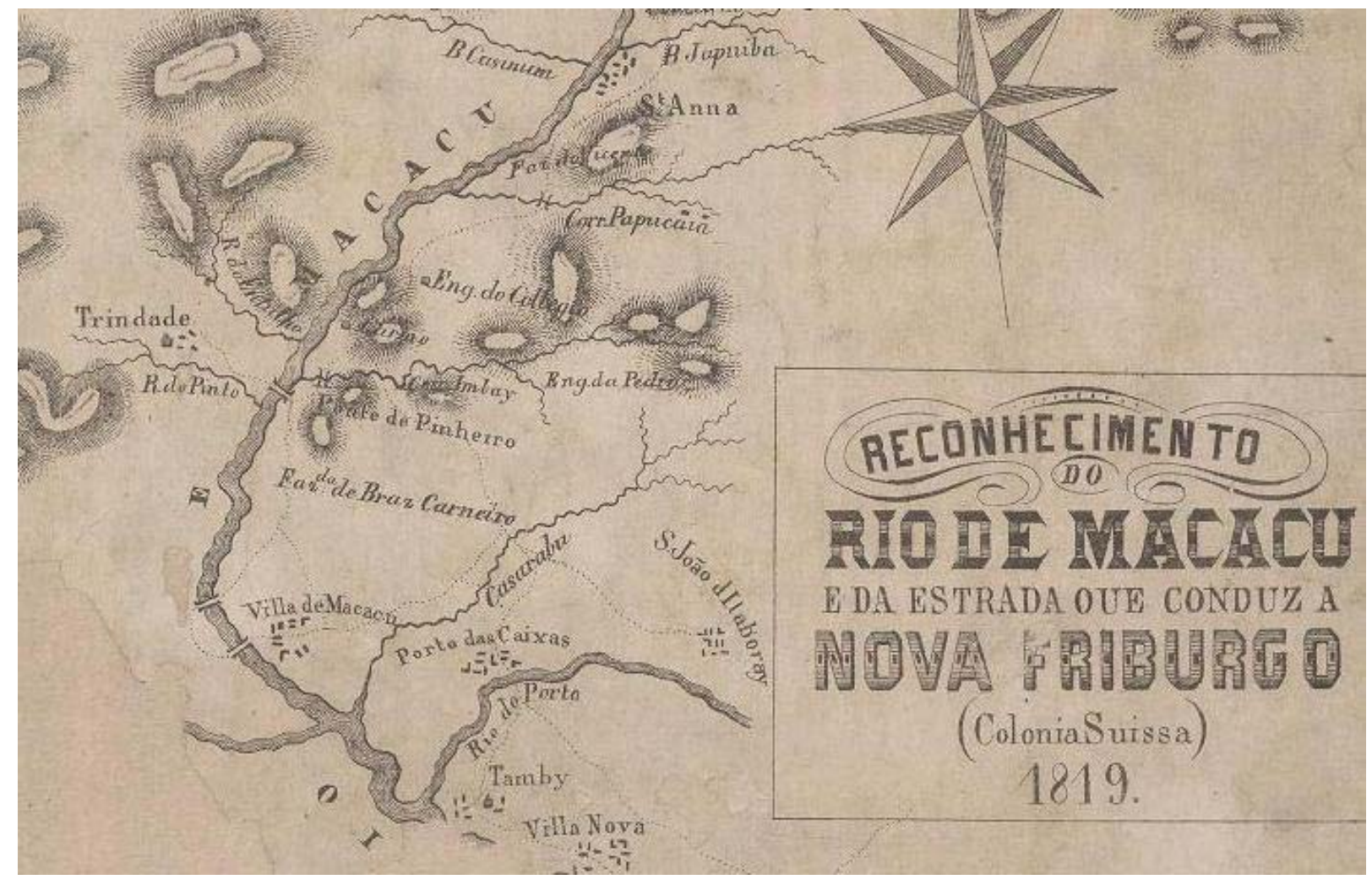

"Reconhecimento do rio de Macacu e da estrada que conduz a Nova Friburgo: (Colônia Suissa)" Lith. do Archivo Militar, 1819. BNRJ ARC.003,13,026. (Catálogo digital, referência cart524755.tif) 
O empreendimento devia dar origem "nas áreas mais afastadas da capitania do Rio de Janeiro, como Cantagalo, a pequenas propriedades que em tudo diferiam das grandes unidades produtivas que, na mesma altura, se contiuíam nos Campos de Goitacazes e no reconcavo da Guanabara" (Domingues, 2007: 145).

Como se pode perceber no mapa "Reconhecimento do rio de Macacu e da estrada que conduz a Nova Friburgo: (Colonia Suissa)", feito em 1819, (sem autoria definida), a divisão das sesmarias concedidas aos colonos obedeceu um padrão geométrico, possuindo um formato retangular (detalhe, figura 10). Ocupação e normatização do espaço se combinavam na busca pela dominação do território. Neste mapa também é possível identificar a propriedade de Brás Carneiro Leão, na beira do rio Macacu, próximo à freguesia de Porto das Caixas.

Coroando a conquista do sertão pela hegemonia portuguesa, encontra-se este empreendimento de colonização estrangeira, como forma de povoar o território para garantir a sua manutenção, mas também como indício de um projeto de civilização das populações. Para Corrêa (2005), “o 'branqueamento' e a conseqüente 'melhoria da qualidade da população", assim como "a ocupação de áreas estratégicas do ponto de vista geopolítico" foram os imperativos dessa nascente política migratória, que a autora associa à herança pombalina de trazer "luzes" à colônia - e conseqüentemente aos sertões incultos.

Tratava-se de transformar em "território usado" os espaços inseridos no território formal metropolitano, se utilizando tanto de uma estrutura material previamente existente, com caminhos e roçados, como criando novas. Para tanto, mobilizavam-se as populações em prol do projeto de povoamento da fronteira, relegando-as a mero instrumento de garantia da integridade territorial. 


\section{Figura 10. Reconhecimento do rio Macacu e da estrada que conduz a Nova Friburgo (detalhe)}

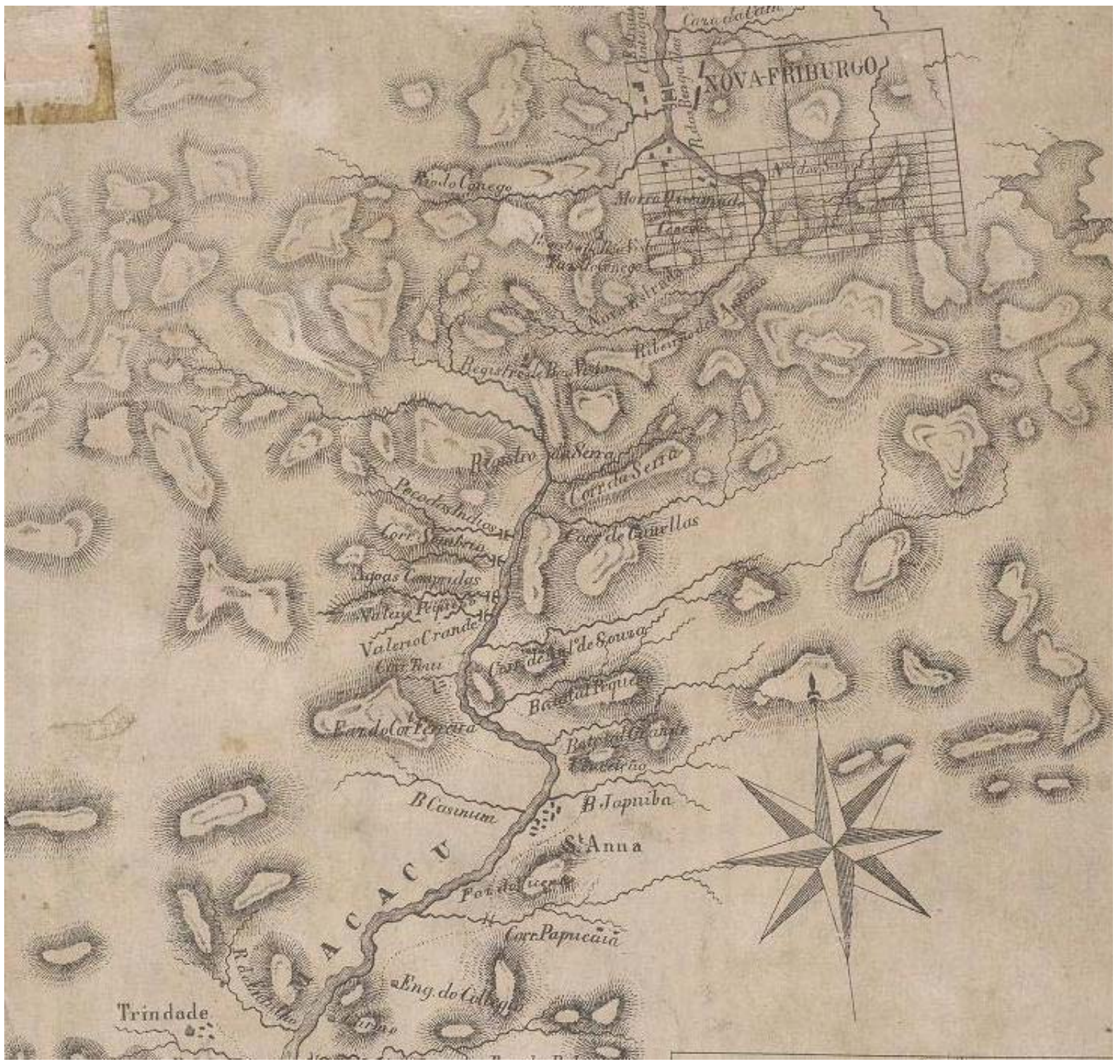

"Reconhecimento do rio de Macacu e da estrada que conduz a Nova Friburgo: (Colônia Suissa)" Lith. do Archivo Militar, 1819. BNRJ ARC.003,13,026. (Catálogo digital, referência cart524755.tif) 


\section{A CAPITAL DO NOVO MUNDO}

\subsection{O Rio de Janeiro: "olho do Brasil", "cabeça do Império"}

Voltemos, pelo sinuoso caminho que atravessa a Serra, para a cidade do Rio de Janeiro, agora para pensá-la como capital de um vasto Reino, numa escala que articulava redes continentais e marítimas.

A cidade que a corte havia encontrado aos poucos ia sendo transformada, pelo impulso de torná-la mais condizente com sua condição cortesã. John Luccock, que em 1808 criticava em muito os costumes locais, inclusive os da Corte, e as más condições gerais da cidade do Rio de Janeiro, passou a ver significativas melhorias a partir de 1813, quando retorna à cidade depois de ausentar-se para outras viagens. Segundo o inglês, o aumento da guarda policial, a abertura de colégios e escolas, a fundação do Jardim Botânico, a extensão das redes dos Correios, assim como a existência de agências de seguros, além de três livreiros, seriam indicativos destas mudanças.

Os célebres comentários do viajante sobre os péssimos modos da realeza portuguesa também são relativizados em seus escritos posteriores, nos quais nota um "grande acrescentamento no conforto e mesmo nos luxos" (1975: 364). E afirma:

na Corte começou a aparecer alguma semelhança para com a magnificência das européias [...], a nobreza local fez-se mais atenta ao bom gosto e propriedade das suas maneiras de vestir, introduzindo-se librés de gala semelhantes às de Lisboa. As casas, com seu mobiliário, realizaram equivalente progresso em conveniência e vistosidade; as carruagens começaram a fazer-se mais numerosas, algumas delas magníficas e, quando a caminho da Corte, faziam-se puxar por cavalos em vez de mulas e servir por lacaios brancos em vez de escravos. (1975: 163).

Pode-se dizer que em 1808 os olhares dos reinóis emigrados ainda estavam voltados para Lisboa. Porém, com o avançar dos anos, eles foram fixando-se no Rio de Janeiro, demonstrando um enraizamento de interesses nesta porção do império português 
(Slemian, 2006). As cartas de Luís Joaquim dos Santos Marrocos são indicativas desta virada: se, logo após a sua chegada, o responsável pela biblioteca real dizia que até dormindo praguejava contra o Brasil, ${ }^{74}$ em 1819 já convidava seu pai e toda a família a virem para "este continente".

Acompanhando-se as cartas de Marrocos, um sem fim de obras e construções revelava a intenção de permanência da realeza na cidade, afinal, despendiam-se montantes consideráveis de dinheiro em riqueza materializada, fixada no solo. Em 1815, Marrocos comentava a seu pai que:

sempre aqui se projeta em obras, e obras grandes: o Palácio de S. Cristóvão, ou a Real Quinta da Boavista, está muito adiantado; o de Santa Cruz vai a reformar-se e aumentar-se. Há plano pronto para um Palácio novo no sítio chamado a Ponta do Caju, orçando-se a obra em 17 milhões. A Capela Real vai dourar-se toda depois da festa do Carmo para estar pronta para a festa da Conceição; entretanto se hão de fazer os ofícios divinos na Igreja dos Terceiros do Carmo, contígua à Capela Real. A senhora D. Carlota vai para o Palácio em que habitou o conde de Galvêas, no sítio de Mata Porcos, que se está preparando, como foi o de Andaraí. ${ }^{75}$

Este processo também é notado por Jean-Baptiste Debret, que declara: "o progresso das construções, que aumenta diariamente a extensão da cidade do Rio de Janeiro, provocou a criação excessiva de inúmeras fabricas de telhas e tijolos (olarias) cuja produção tem mercado garantido" (1978, v II, 346).

Podemos dizer que este processo, de enraizamento material no espaço urbano, é uma faceta do que Maria Odila Dias (1972) denominou de interiorização da metrópole. Segundo a autora, a instalação da Corte na América portuguesa acarretaria uma série de mudanças políticas cruciais para a constituição do processo de independência. Mais especificamente, ocorreria uma ruptura interna nos setores políticos do velho reino e, ao mesmo tempo, um estreitamento de interesses portugueses com os das grandes famílias rurais "brasileiras" (interesses voltados para a produção, mas não separados das

\footnotetext{
74 "Meu pai, quando se trata das más qualidades do Brasil, é para mim matéria de vasta em ódio e zanga, saindo fora dos limites da prudência; e julgo que até dormindo praguejo contra ele" (21/11/1812). Memórias e cotidiano do Rio de Janeiro no tempo do rei: trechos selecionados das cartas de Luis Joaquim dos Santos Marrocos. Biblioteca Nacional do Rio de Janeiro, acervo digital.

${ }^{75}$ Ibidem, carta de 29/06/1815.
} 
atividades de comércio e transportes), frente à perda do papel de intermediário que Portugal tinha no comércio colonial.

Afinal, pela primeira vez:

configuravam-se nos trópicos portugueses preocupações próprias de uma colônia de povoamento e não apenas de exploração ou feitoria comercial, pois que no Rio teriam que viver e, para sobreviver, explorar os 'enormes recursos naturais' e as potencialidades do império nascente, tendo em vista o fomento do bem-estar da própria população local (Dias, 1972: 182).

A partir de então, diretrizes como povoamento, fomento à agricultura e constituição de uma rede de comunicações passam a fazer parte da política da Coroa, construindo-se um aparato material que tinha como centro a cidade do Rio de Janeiro, capital do Reino Unido de Portugal, Brasil e Algarves em 1815. Logo nota-se uma reserva de privilégios para o Centro-Sul, com a criação de uma série de tributações às capitanias do Norte, para custear gastos com a Corte.

Pode-se dizer que até 1808 havia uma política contraditória na atividade colonizadora, que oscilava entre a dispersão, de forma a evitar a união de interesses entre as capitanias, e a aproximação, conforme investiga Maria de Lourdes Viana Lyra (1992). A política de cooperação entre as capitanias se evidencia nas instruções de Martinho de Mello e Castro (Ministro da Marinha e dos Negócios Ultramarinos entre 1770 e 1795) ao governador da capitania de São Paulo, a partir da constatação de que era necessário unir esforços para combater inimigos comuns:

Todas as Colonias Portuguezas são de Sua Magestade, e todos os que as governam são vassallos seus. E n'esta intelligencia tanta obrigação tem o RJ de soccorrer a qualquer das Capitanias do Brasil, como cada uma delas de se soccorrerem mutuamente umas ás outras [...]. Sendo certo que n'esta reciproca união de poder, consiste essencialmente a maior força de um Estado, e na falta d'ella, toda a fraqueza d'elle ${ }^{76}$.

\footnotetext{
76 "Instrucção militar para Martim Lopes Lobo de Saldanha - Governador e Capitão-General da Capitania de S. Paulo" Salvaterra de Magos, 14 de janeiro de 1775. Revista do Instituto Histórico e Geográfico Brasileiro, 1863.
} 
Como vimos no capítulo anterior, a implementação de novos caminhos, após a vinda da corte, passa a ser um exemplo da necessidade de prover as outras capitanias de comunicação com a nova capital, já que existiam muitas dificuldades a ser suplantadas nos trajetos entre as capitanias da colônia portuguesa da América, apontada por diversos viajantes:

Com a localização do eixo dinâmico da ação centralizadora do Estado absolutista português no Rio de Janeiro, criou-se um ponto de convergência, isto é, um centro de união, não apenas entre as várias partes do território chamado Brasil, como entre este e o reino de Portugal na Europa... (Lyra, 1992: 129).

Essa mudança na geografia colonial implicaria um rompimento com a política dispersiva e uma busca pela unidade brasileira, que se tornaria uma grande causa a ser defendida no processo de construção de uma nação independente.

Segundo relato de John Luccock (1975: 376):

quando a Corte chegou ao Rio, se verificou que as Colônias consistiam de partes tão desconjuntadas que, à menor agitação, estariam prestes a se desmanchar em pedaços, tornando muito precária a situação dos reais imigrantes. Foi necessária toda a habilidade do Governo e todo o poderoso apoio que recebeu da Inglaterra, para defender a administração de declarado desacato, para manter o Brasil todo dentro dos mesmos laços, para desviar a atenção do povo, de Lisboa para o Rio, para levá-lo a sentir nesta última cidade o centro de sua unidade, a Capital de sua população tão grandemente difusa, a fonte de sua segurança, o foco e a nascente de sua riqueza e de sua honra. [grifo nosso]

Ou seja, o Rio de Janeiro era o centro da unidade do Império português, a capital deste extenso território disperso entre os quatro continentes. A importância da condição da cidade enquanto capital do Império não é pequena, afinal, como definiu Paul Alliès:

a capital se distingue da cidade que ocupa geograficamente. Seu papel de gestão e de dominação a faz preencher uma função de dupla tutela: sobre a cidade onde ela está assentada e sobre as cidades cujo aparelho político-administrativo submete-se a ela. A capital não é uma cidade maior ou mais forte que as outras. Ela é de natureza diferente [...] Ela se apóia sobre o território de uma cidade, desdobra suas funções e as difunde de 
uma maneira hierarquizada num espaço estatal. A capital seleciona, assim, as redes de vilas mercantis e decompõe o policentrismo destas. (1980: 92)

Para Claude Raffestin (1980: 172), a capital expressa uma representação política e materializa suas estratégias. Dessa maneira, ao simbolizar a centralidade de determinada configuração política, sempre à capital se contrapõe uma marginalidade. Para este autor, a mudança de uma capital de lugar muitas vezes é somente uma mudança espacial, mas às vezes traz uma ressemantização, uma ressignificação simbólica, que acreditamos ser bastante fortes no caso do Rio de Janeiro. Afinal, a mudança da capital do Império português implica no fim da condição colonial para o Brasil, gerando a necessidade de se criarem novas referências, frente ao ineditismo da situação.

Neste ponto, podemos agregar à discussão o conceito de "capitalidade", trabalhado por Maria Fernanda Bicalho em artigo recente (2006). Segundo a autora, não basta somente uma decisão política de afirmação de uma capital, mas é necessário sustentar sua centralidade:

Só podemos falar de capitalidade na condição de este centro chegar a repercutir a sua influência num determinado espaço, ou seja, sobre um Estado, independentemente da configuração que este assuma. Há, portanto, a considerar uma vertente dinâmica, expressa na capacidade que o centro tem de estruturar e estabelecer hierarquias no interior de um território e com ele sustentar ligações. Trata-se, afinal, de analisar a rede sobre a qual se realiza a articulação entre o centro e as suas periferias" [grifo nosso].

Se a cidade do Rio de Janeiro já se estabelecia com centro de uma rede que articulava o centro-sul do Brasil e outras partes do Império português, com a chegada da família real era necessário afirmar e ampliar sua capitalidade, fazendo os fluxos, antes direcionados a Lisboa, convergirem em sua direção. Com a elevação do Brasil a Reino Unido a Portugal e Algarves, quando se oficializa o papel de capital que o Rio de Janeiro já vinha exercendo, fortalece-se a idéia da cidade enquanto "cabeça do Império", centro econômico e político desta extensa rede transcontinental. 
Pierre Musso (2003) alega que no século XVIII a idéia de rede era associada aos fluxos do corpo humano, implicando que toda a rede fosse comandada por uma "cabeça", ou seja, por um centro de decisões. Claude Raffestin (1980: 187) também chama a atenção para a analogia, realizada até os dias de hoje, entre sistemas de circulação e fluxos do corpo humano, lembrando do perigo que este tipo de prática representa, ao naturalizar um instrumento que é criado por atores e reproduzido em função de determinados projetos políticos e econômicos.

Essa associação é historicamente compreensível, entretanto, uma vez que princípios fundamentais da descrição espacial encontram raízes na natureza humana, começando pelo próprio corpo $^{77}$ (Arheim, 1988). Para Goschler (2005), "nações, assim como cidades e todas as comunidades humanas e políticas, são frequentemente conceituadas metaforicamente como pessoas ou corpos". Nesse sentido, parece interessante refletir sobre algumas metáforas encontradas nos discursos coevos. Além de "cabeça do Império", na descrição de Antonio D’Oliva Sousa Sequeira ${ }^{78}$, o Rio de Janeiro era também, para o viajante prussiano Johan Emmanuel Pohl, o "olho do Brasil". Ambas as metáforas indicam de alguma maneira a centralidade que a cidade exercia, sendo tanto a "cabeça" quanto o "olho" associados a comando, poder e controle.

Se o Rio de Janeiro era "cabeça" do Império, enquanto centro pensante e articulador de seus membros restantes, era também o "olho" do Brasil, por ser a porta de entrada deste país e o posto central de onde se avistava e se controlava o território. Esta centralidade concedida ao sentido da visão tem raízes no Iluminismo, quando, a partir do que já haviam anunciado Descartes e Bacon, se lançam as bases sistemáticas do triunfo da visão. Denis Cosgrove afirma que, no racionalismo ocidental "o olho se apresenta como uma janela para a alma racional" (2002: 65), sendo frequentemente associado a conhecimento e razão ${ }^{79}$.

\footnotetext{
${ }^{77}$ Walter Mignolo (2001) destaca que tanto a cosmologia cristã medieval quanto a cosmologia mexica, por exemplo, partiam do corpo humano para pensar e dividir o mundo.

${ }_{78}$ Antonio D'Oliva de Sousa Sequeira, tenente do $6^{\circ}$ Regimento d'Infantaria, e estudante de Matemática na Universidade de Coimbra, escreveu o "Projeto para o estabelecimento político do Reino-Unido de Portugal, Brasil e Algarves, offerecido aos illustres legisladores, em Cortes Geraes e extraordinarias" em 1821, em que considera: "Portugal em relação ao Brasil, apenas um dos membros extremos". (ver capítulo 1 desta dissertação, p. 22).

${ }^{79}$ Michel Foucault (2002: 216), em artigo intitulado "O olho do poder", analisa a necessidade de controle e visibilidade, que ganha destaque no século das "Luzes", diferenciando a dupla dimensão atribuída a este "olhar": por um lado, e principalmente, trata-se de um olhar "dominador e vigilante" (2002: 215), como no panóptico de Bentham, mas por outro, no sentido colocado pelos atores da Revolução Francesa, o
} 
Conforme exposto no capítulo I, a instalação da corte no Brasil teria acelerado, na escala urbana, o processo de "abertura" das janelas, até então fechadas, aos olhos alheios, incentivando um convívio público. Os cerimoniais da realeza contribuíam para a afirmação deste novo imperativo e é interessante notar que, se antes o príncipe regente marcava sua presença à distância, através de retratos expostos durante as festas ${ }^{80}$, agora era possível, aos habitantes do Rio de Janeiro, ver o soberano com seus próprios olhos.

Na missão de afirmar a soberania do rei e a unidade do seu governo, a festa aparecia como um momento ímpar de consolidação de um imaginário. Para Iara Lis Souza (1998: 237), "dar-se a ver" 81 , no teatro e nas festas reais, era uma maneira do soberano entrar em contato com seus súditos, transformando o mundo num grande palco onde ele exibia sua persona. De modo semelhante, Lilia Scharwcz (2006: 272) infere que:

As aparições públicas do príncipe [e depois rei] d. João - seja nos cortejos reais, seja nas procissões - convertiam-se em demarcações territoriais e vinculavam sua imagem à própria representação do império português, espalhado pelos quatro cantos do mundo e governado a partir da [antiga] colônia”.

Durante o reinado de d. João VI no Rio de Janeiro ocorreram várias ocasiões festivas de peso para o cotidiano da cidade e seus domínios, começando com a elevação do Brasil a Reino Unido de Portugal, Brasil e Algarves, decretado em dezembro de 1815 mas celebrado apenas em 6 de fevereiro de 1816. Na sequência desenrolam-se momentos tensos: a morte de d. Maria I, em março de 1816, e as turbulências da Revolução Pernambucana de 1817. Abaladas as previsões e seguranças refletidas nas repetições do calendário, logo se tenta retomar o curso das comemorações, com a chegada da princesa Leopoldina, em fins de 1817, seguida de seu aniversário em janeiro de 1818, a aclamação de d. João VI, em fevereiro de 1818, seu aniversário em 13 de maio do

olhar enquanto visibilidade das ações teria uma dimensão positiva, pois contribuiria à formação de uma opinião pública, coibindo injustiças e maus comportamentos.

80 “....a ausência física do monarca era compensada por representações e especialmente por seu retrato, o que permitia sua presença simbólica, elemento fundamental na idealização da unidade social e no fortalecimento dos laços de pertencimento à Nação portuguesa" (Lopez, 2004: 44).

${ }^{81}$ Diziam os editores da Gazeta que "enchia a todos de alegria a Augusta Presença de Sua Magestade, com o magnifico Manto Real, todo recamado de ouro..." [grifo nosso]. Gazeta do Rio de Janeiro, 10/02/1818, edição extraordinária. Biblioteca Nacional do Rio de Janeiro digital. 
mesmo ano e, por fim, o casamento de d. Pedro I com a princesa austríaca (Lopez, 2004).

Todas estas celebrações sempre contavam com diversos elementos, como a arquitetura efềmera, as iluminações, fogos de artifício $^{82}$, típicos da festa barroca, em que importava a novidade, a invenção e o caráter fugidio do evento. Para a ocasião da aclamação de d. João, realizada em 6 de fevereiro de 1818, o Paço Real foi cuidadosamente preparado e todas as ruas próximas enfeitadas. Mas o ponto alto da festa:

era mesmo a varanda, que ocupava toda a frente do Convento do Carmo, desde o passadiço sobre a rua Direita - que unia o convento onde vivera d. Maria - até a Capela Real. Não faltaram detalhes nesse cenário efêmero, que deixava o rei visível de onde quer que se quisesse observar. (Schwarcz, 2006: 279)

Desenhada por João da Silva Moniz e executada por Caetano Alberto Nunes de Almeida ${ }^{83}$, sob auspícios do patrono Visconde do Rio Seco, a varanda "occupava ella toda a face do Real Paço, contigua a Capella [e] compunha-se de 18 arcos elegantes" ${ }^{\text {" }}$, acomodando o monarca, os nobres e as "pessoas distintas". Na descrição realizada pelos editores da Gazeta do Rio de Janeiro, durante a aclamação:

Para que o povo tivesse a satisfação de ver a Sua Magestade se retirarão para a parte da parede as pessoas, que estavão junto á grade.[...] O immenso concurso do povo que estava em frente da Varanda, e que atulhava as ruas contiguas, rompeu em unanimes e não interrompidos vivas, que mostravão da maneira mais evidente o prazer, que transbordava nos corações de todos. Multiplicavão-se os brados, e os seus echos erão encontrados pelas vozes dos espectadores, que ornavão as janellas, e até occupavão os telhados e as torres das Igrejas, e todos os lugares eminentes...

A construção da Régia Varanda nos coloca a questão das "janelas" 85 enquanto metáfora da vida pública, porém agora em nova escala: depois de elevada à condição de capital

\footnotetext{
82 "Então salvarão as fortalezas e os navios de guerra surtos neste porto, e se elevarão muitos fogos de artifícios, que arremedavão hum regular fogo rolante com perto de dois mil tiros". Descrição da Aclamação de d. João VI. Gazeta do Rio de Janeiro, 10/02/1818.

${ }^{83} \mathrm{Na}$ Biblioteca Nacional do Rio de Janeiro encontra-se a "Planta e prospecto geometrico da Regia Varanda que se eregio para a Feliz Aclamação do Nosso Augusto Soberano o S. D. João VI com a Côrte do Rio de Janeiro".

${ }^{84}$ Gazeta do Rio de Janeiro, 10/02/1818.

${ }^{85}$ No dia da aclamação de d. João VI gritava-se:

"Grandes, pequenos, homens, mulheres

Pelas ruas, janelas e pela praça

Com esta voz somente os ares fendem $=$
} 
do Reino Unido, a cidade do Rio de Janeiro necessitava também afirmar ao resto do mundo como a capital monárquica de um grande império.

A elevação em 1815/1816 trouxe, para os portugueses do Reino e a comunidade internacional, algumas inquietações a respeito da possibilidade de um país europeu ser governado a partir do "Novo Mundo". O abade De Pradt, por exemplo, em seu texto sobre o Congresso de Viena publicado em 1816, sugere um temor de que a América pudesse ter colônias na Europa e completa: "Neste caso, poderia a Europa tolerar esta mudança, ou se submeter a leis transmitidas pelos seus próprios filhos, de outro hemisfério?" 86 .

O problema inicia-se, segundo ele pelo fato de que:

Portugal preservou seus domínios, mas perdeu seu soberano. A partida do príncipe regente para os 'Brasis' [the Brazils] deu início a uma nova ordem das coisas. É sobre ele que pretendemos falar. Deve a Europa permitir que uma de suas porções receba ordens da América? Essa é uma questão que a residência do soberano de Portugal no Brasil sugere.

Para De Pradt, no futuro "o mesmo soberano não pode[ria] governar ambos [Brasil e Portugal]", sendo necessário e urgente fazer-se uma escolha, entre as difíceis opções que apresentava:

Se ele permanece na América, Portugal nunca pode se submeter a tornar-se uma província do Brasil: Se ele retorna a Portugal, o Brasil, que experimentou o conforto e o valor de um governo local, vai querer sempre desfrutá-lo. Portugal, assim como a Espanha, não mais teria assuntos na América; e como o Brasil está posicionado em meio às movimentações que agitam o continente americano, é evidente que será afetado por isso. Em todos os casos, deve ocorrer uma separação entre Portugal e Brasil.

Hipólito José da Costa, português contestador que tocava o seu periódico Correio Braziliense a partir do exílio em Londres, comenta o fato da elevação do Brasil a reino sem, contudo, tocar nesta questão da localização do centro de poder. Admitindo que não

Viva El Rei, viva, viva!"

Bernardo Avelino Ferreira e Souza. "Relação dos festejos que à Feliz Aclamação do Mui Alto, muito poderoso, fidelíssimo Senhor D. João VI Rei do Reino Unido de Portugal, Brasil e Algarves...", 1818. Apud Lopez, 2004: 74.

${ }^{86}$ The Congress of Viena. Londres, 1816, p. 160. 
poderia mais competir aos países antigamente dominados por Portugal "a denominaçao de colonia", o ilustrado acredita que esta "mudança de nome" deveria ser acompanhada de uma mudança substantiva que visasse, de fato, consolidar uma união.

Escrevia ele:

Esperamos pois, com summa anxiedade, pelos planos, que terao meditado os Ministros da Corte do Rio de Janeiro, para estabalecer a unidade de systema de administração, no Reyno, a que deram o nome de Unido. De uma cousa podem esses Ministros estar seguros; e he, que os Portuguezes se não hao de satisfazer só com o nome de união; e que se faltar a realidade, uma vez que declararam a nomenclatura, o erro do presente modo de administração sera tao conspicuo, que ninguem lhe perdoará as más consequencias $^{87}$.

Já o viajante inglês John Luccock, presenciando os acontecimentos a partir do local diretamente beneficiado pela mudança, faz uma avaliação um pouco mais otimista sobre as consequências do que se dizia ser apenas uma mudança de nome. (1975: 376, grifo nosso):

embora os autores do projeto nele não vissem senão pouco mais que uma alteração de nome, o povo sentiu que penetrava numa era nova de existência política, pareceu sentir-se guindado a categoria mais elevada na escala dos seres humanos, e viu nele uma prova irrefutável de que estava fixado seu destino, a saber, que o Brasil, no futuro, ainda seria considerado como uma das nações do mundo, deixando de ser sacrificado aos interesses de outra nação. $\mathrm{O}$ acontecimento infundiu na alma do povo um sentimento de independência, uma consciência própria de sua importância e a resolução de manter sua nova dignidade.

Parecia que se estava vivendo um grande acontecimento histórico que reservaria ao nascente país inúmeras felicidades por vir. Nestes discursos, identifica-se, no Brasil que se formava, a idéia de uma enorme potencialidade, formulando-se a imagem de um país cujo futuro conteria grandes êxitos ${ }^{88}$.

Johann Emanuel Pohl, escrevendo em 1818, descreve a baía de Guanabara como "pujante e grandiosa", reservando ao Rio de Janeiro a alcunha de "Olho do Brasil". E completa:

\footnotetext{
${ }^{87}$ Correio Braziliense, fevereiro de 1816, p. 296. Biblioteca Nacional digital.

${ }^{88}$ Nas memórias do Padre Perereca, sempre exaltando a monarquia, lê-se: "ó venturoso Brasil, contemplo a tua futura grandeza" [grifo nosso]. (Santos, 1981: 188).
} 
se algum ponto do Novo Mundo merece, por sua situação e condições naturais, tornarse um dia teatro de grandes acontecimentos, um foco de civilização, e cultura, um empório do comércio mundial, é, ao meu ver, o Rio de Janeiro. [...] De bom grado a fantasia paira sobre o futuro de tão sedutor país, que tem um presente pouco desenvolvido e, por assim dizer, não tem passado (1976, p. 38, grifo nosso).

Dentro dessa chave, ao mesmo tempo em que se valiam da esperança de construir um potente Império num mundo novo, os eventos festivos eram compostos por simbologias que tentavam transferir o peso da tradição da monarquia portuguesa para o cenário "sem passado" dos trópicos. Segundo Lilia Schwarcz, "decorava-se o evento com monumentos frágeis como o momento político; mas as alegorias clássicas e referências ao passado davam às celebrações a tradição que lhes faltava e a história de que careciam" (2006: 278). Assim, por exemplo, a reunião de monumentos efêmeros grego, romano e egípcio, durante a aclamação de d. João, buscava estampar aos olhos dos presentes uma erudição ocidental, causando "agradável sensação à vista simultânea", segundo o Padre Perereca (Santos, L. G. dos, 1981, tomo II: 32).

Pode-se dizer, de acordo com Schultz (2006: 131), que "potenciais contradições e tensões eram dirimidas pela festa e pelo resgate de eventos históricos que davam força à imagem do Império unido". Isso, contudo, não eliminava os temores de eventuais revoltas, frente ao clima de tensão no ar (principalmente em 1818), relatados por viajantes como Luccock e Debret e discutidos por Emilio Lopez (2004).

\subsection{O olho sobre o Brasil: a paisagem, o mapa, o relato}

O período joanino no Rio de Janeiro também representou uma expansão do olhar sobre o restante do território, num esquadrinhamento das potencialidades contidas nas terras brasílicas. O olhar do conhecimento se estende pelo espaço em busca de seu domínio, gerando, no gênero da escrita, relatos, roteiros e crônicas, e no gênero da produção iconográfica, a paisagem e o mapa (ambos instrumentos fundamentais do conhecimento geográfico). 
As expedições de exploração do território não eram novidade quando a corte aportou no Rio de Janeiro. Pelo contrário, desde meados do século XVIII, sobretudo a partir de 1770, a Coroa inicia o patrocínio de memórias que desvendassem o interior da América Portuguesa e propusessem inovações para o progresso material do país, como medidas para o aumento da população, incremento do comércio e melhorias agrícolas (Dias, 2005: 44). Segundo Maria Odila Dias, os estudos realizados nas Universidades européias de Coimbra, Montepellier, Edimburgo, Paris e Estrasburgo ${ }^{89}$, no fim do século XVIII seriam responsáveis pela formação intelectual de toda uma geração, por trás dos escritos destas memórias.

De todo modo, o incentivo a este tipo de pesquisa aumentaria após a vinda da Corte, sob comando do Ministro D. Rodrigo de Sousa Coutinho, e com a criação da Impressão Régia. A atuação do órgão foi fundamental para a publicação de estudos importantes, como os onze volumes do "Fazendeiro do Brasil", além de traduções para o português de diversos tratados sobre as culturas agrícolas. Coutinho sempre é lembrado como grande apoiador deste tipo de iniciativa e, para Iara Lis Souza (2003: 614), foi através de seu programa de reformas que o Brasil foi saindo de sua condição "genérica" 90 e ganhando uma especificidade.

Além do "Fazendeiro do Brasill", podemos listar, entre as publicações da Impressão Régia, uma infinidade de roteiros de exploração do interior do país, visando a conexão entre a capital e as vilas e cidades mais distantes, como São Luis do Maranhão ou Belém do Pará. E pode-se considerar que a grande obra geográfica do período é a “Corografia Brasílica”, de Aires de Casal, editada pela Impressão Régia em 1817. Nela, o padre descreve todas as províncias (assim chamadas desde a elevação do Brasil a reino), incluindo a Cisplatina e a Guiana, sob domínio português à época.

Juntamente com memórias, relatos e roteiros de viagem, a Impressão Régia também publicou diversas gravuras e mapas. Inclusive, conforme coloca Renata Santos (2008), uma das duas primeiras encomendas técnicas do órgão, em 1809, foi:

\footnotetext{
${ }^{89}$ Lembremos que somente em 1826 se criaram cursos de ensino superior no Brasil, como os de direito em Olinda e São Paulo (diferentemente da América espanhola, onde desde o início colonização a metrópole se preocupou em criar Universidades).

${ }^{90}$ Afinal, o próprio Coutinho afirmara que as províncias da América eram denominadas pelo "genérico nome de Brasil”. Apud Lyra, 1994: 123.
} 
a gravação da planta da cidade [do Rio de Janeiro] 'tirada' do Arquivo [Militar], ou seja, levantada pelos oficiais desse estabelecimento [...]. A planta foi desenhada pelo primeiro-tenente Ignácio Antonio dos Reis e gravada a buril por Paulo dos Santos Ferreira Souto. Sua publicação foi anunciada na Gazeta do Rio de Janeiro [...] somente em 13 de maio de 1812, sendo vendida por 6.400 réis.

A autora prossegue dizendo que a geografia era onipresente nas imagens produzidas pela Impressão Régia (e muitas vezes anunciadas na Gazeta), na forma de "mapas, plantas, planos de batalhas e atlas, tanto para atender às necessidades militares quanto para possibilitar a localização espacial por parte do público comum" (Santos, 2008: 38). Nesta última categoria poderíamos listar os mapas de batalha saídos em números extraordinários da Gazeta em 1809 e 1810. E destaque-se que, além de "estampas e Cartas Geográficas" "91, também era comum a venda de "retratos, paisagens, registros de santos, 'bentinhos' e caricaturas" (Ferreira, 1994: 437).

Em meio às descrições que se faziam do território, destacamos a paisagem e o mapa por seu poder de elaboração imagética ${ }^{92}$. Ambas as formas de representação, ainda que destinadas a distintos fins, tiveram bastante peso para a formação de uma identidade nacional, a partir da construção de imagens do território. Segundo Jean Marc-Besse (2000: 37), desde o Renascimento, “o olhar do pintor e o olhar do cartógrafo não estavam então separados, ainda que não se confundam. Eles participam de uma mesma atitude cognitiva e de uma mesma competência visual, que compartilham na época com a dos médicos, arquitetos, engenheiros”. Esta atitude cognitiva só passou a ser possível a partir da idéia de perspectiva e pela busca de uma veracidade descritiva, através da proporção.

\footnotetext{
${ }^{91}$ Segundo anúncio da Gazeta do Rio de Janeiro, em 08/08/1818:

"José Bellieni, italiano, tendo ultimamente chegado de Paris, vai abrir huma loja na rua do Ouvidor, $\mathrm{n}^{\circ}$ 72 , com todas as qualidade das melhores estampas e Cartas Geográficas, princípios de desenho, tendo tambem endouraduras para fazer molduras a preço commodo".

${ }^{92}$ Denis Cosgrove (2008: 6), em livro recente sobre a relação entre geografia e visão, coloca que: "em ambos os modos de cognição geográfica [a paisagem e o mapa], e em suas constantes interações, imagens gráficas e pictóricas jogam papéis ativos e criativos que levam o significado da representação muito além da mera transcrição dos fatos ambientais e espaciais".
} 
Figura 11. Prospecto da cidade de S. Sebastião do Rio de Janeiro. Luis dos Santos Vilhena, $1775^{93}$.

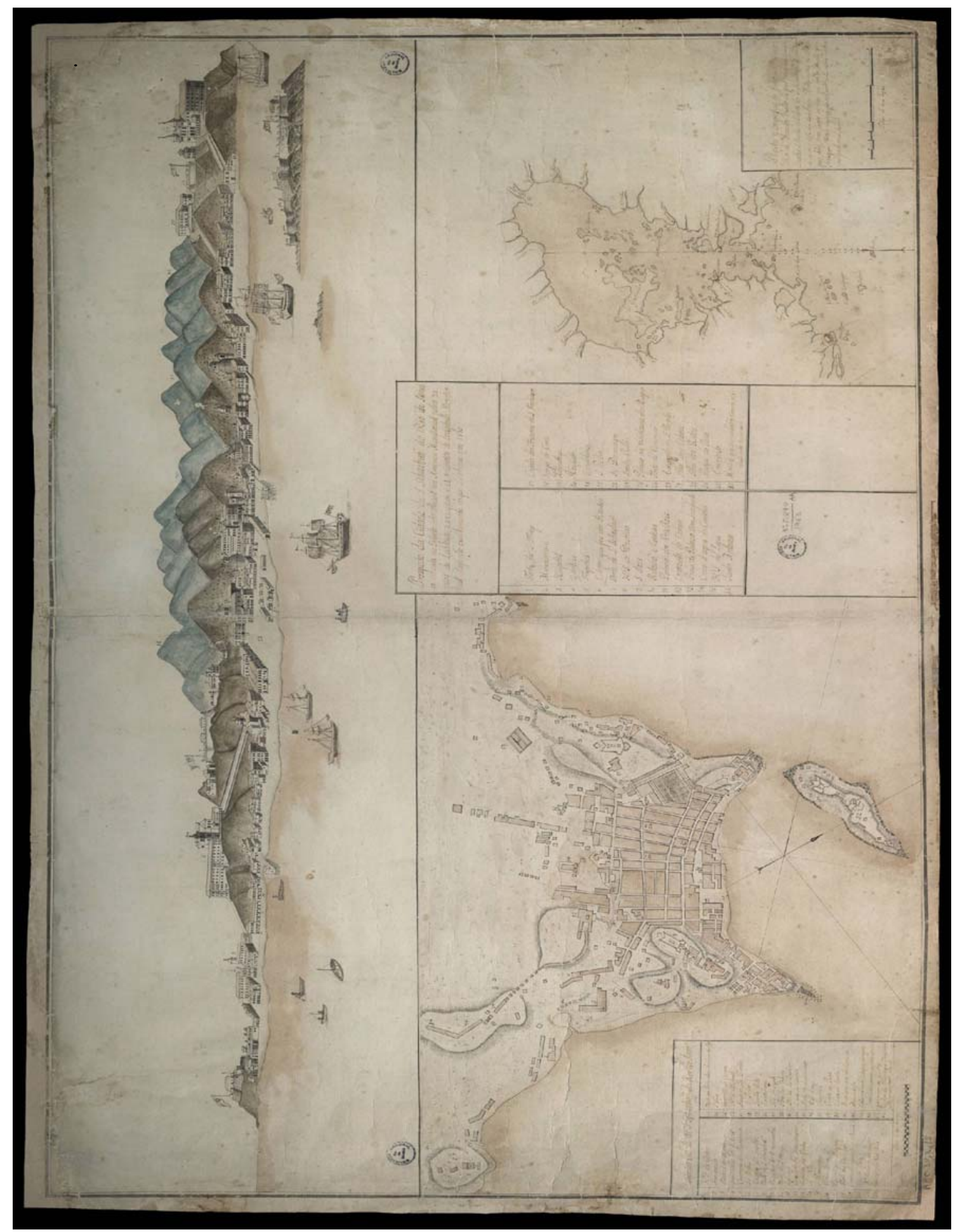

Biblioteca Nacional do Rio de Janeiro, catálogo digital. ARC.030,02,015

\footnotetext{
${ }^{93}$ Vislumbra-se um exemplo de combinação de uma vista topográfica com dois registros cartográficos em diferentes escalas (o plano da cidade e a sua localização na baía de Guanabara), realizado em fins do século XVIII por Luis dos Santos Vilhena
} 
De todo modo, enquanto o mapa, apesar de ser instrumento de utilidade prática, exigia maior abstração, as "vistas" de cidades eram bastante atrativas e cumpriam o papel de facilitar o reconhecimento de um lugar, dotando-o de sentido simbólico (Maderuelo, 2008). Para Javier Maderuelo (2008: 73), “as vistas topográficas são o precedente mais próximo [...] do que se começaria a denominar com propriedade "paisagem"”. Justamente, ao longo do XIX, os álbuns com estampas de vistas de cidades se constituiriam em grande sucesso editorial no Rio de Janeiro (Ferreira, 1994).

Lilia Schwarcz (2008: 119), em livro que investiga a estadia do pintor francês Nicolas Antoine Taunay no Brasil, ressalta que:

Se o gênero da paisagem continuava sendo considerado inferior ao de história, era não obstante muito tradicional e o seria ainda mais, ao passar a identificar-se com discursos de identidade nacional em inícios do século XIX. [...] A paisagem passava a representar a nacionalidade, um 'jardim interno, um senso possível de identidade': o lugar a que se pertence.

A produção, tanto de mapas quanto de gravuras ou pinturas de paisagens sobre o território luso-americano sem dúvida é incrementada com a instalação da corte joanina no Rio de Janeiro e a conseqüente abertura dos portos às "nações amigas". A partir deste fato, fica liberada a entrada de viajantes estrangeiros, até então bastante restrita, ocasionando o que Sérgio Buarque de Holanda (1975: 12) denominou de um "novo descobrimento do Brasil":

A não ser no Quinhentos e, até certo ponto, no Seiscentos, nunca o nosso país parecera tão atraente aos geógrafos, aos naturalistas, aos economistas, aos simples viajantes, como naqueles anos que imediatamente se seguem à instalação da Corte portuguesa no Rio e à abertura dos portos ao comércio internacional. O fato acha em si mesmo sua explicação. A contar de 1808 ficam enfim suspensas as barreiras que, ainda pouco antes, motivaram o célebre episódio daquela ordem régia mandando atalhar a entrada em terras da Coroa de Portugal de 'certo Barão de Humboldt, natural de Berlim', por parecer suspeita a sua expedição e sumamente prejudicial aos interesses políticos do Reino. De modo que a curiosidade tão longamente sofreada pode agora expandir-se sem estorvo, e não poucas vezes, com o solícito amparo das autoridades.

Desde meados do século XVIII a Europa se lançava a um "redescobrimento" do mundo, mas agora com intuitos distintos do primeiro expansionismo, que se remetiam 
principalmente a uma apropriação científica da natureza tropical. Através da figura dos viajantes, organizados ou não a partir de expedições cientificas, um mundo pitoresco era revelado aos europeus. A partir de 1808 estas expedições científicas, e também artísticas, produziram um conhecimento sistemático sobre o território luso-americano, finalmente aberto a olhares externos.

Se no século XVIII já não era possível conceber um sábio que não tivesse viajado e visto o mundo com seus próprios olhos (Capel, 1985), no século XIX a valorização da experiência empírica se afirma e se expande, consolidando a crítica à postura científica dita de "gabinete". O viajante francês Auguste de Saint-Hilaire, que percorreu províncias do Brasil entre 1816 e 1822, correspondia a este "novo perfil do viajantenaturalista idealizado no meio cientifico parisiense: pesquisa in loco, especialização, capacidade de produzir informações balizadas, publicação dos resultados” (Kury, 2001), sendo elogiado por Humboldt pelas "observações preciosas que ele fez nos próprios sítios" $" 94$ ).

Pode-se identificar a gênese da geografia moderna nestas expedições científicas, que visavam explorar e testemunhar 'outros' mundos, incluindo o máximo possível de descrições visuais e imagens gráficas ou pictóricas (Cosgrove, 2008). Se a Geografia, como clamam muitos, nasceu com Humboldt, não é à toa que o olhar e o trabalho de campo representaram uma das dimensões fundamentais desta ciência.

Segundo Elizabeth Mendes, os viajantes que aportaram no Rio de Janeiro entre 1808 e 1822 podiam ser classificados como: naturalistas, assim como Auguste de SaintHilaire, Edward Pohl e Johann von Spix e Carl von Martius, o Barão de Langsdorff e o Príncipe Maximilian Wied de Neuwied; artistas, como Jean Debret, Nicolas Taunay e os membros da missão artística francesa; militares, como os prussianos Leithold e Raugo; alguns especialistas contratados pela Coroa para um serviço específico, como o mineralogista Eschwege; e ainda os viajantes renomados, membros de uma burguesia

\footnotetext{
94 “...o que concede verdadeiro valor a objetos tão numerosos, o que distingue o viajante cientista do simples coletor, são as observações preciosas que ele fez nos próprios sítios, para fazer avançar o estudo das famílias naturais, a geografia das plantas e dos animais, o conhecimento das variedades de solo e o estado de seu cultivo". Trecho de discurso de Alexander von Humboldt sobre Saint-Hilaire. Raport verbal fait à l'Academie des sciences sur un ouvrage de M. de Saint-Hilaire intitulé : Plantes usuelles de Brasiliens. (apud Kury, 2001)
} 
comercial inglesa e francesa, como John Luccock, Koster e Tollenare, geralmente interessados em verificar assuntos de importância econômica.

Muitos desses viajantes realizavam sozinhos a sua empreitada ${ }^{95}$, mas havia também o envio de missões, como a missão artística francesa (1816), chefiada por Joaquim Lebreton, e a expedição científica enviada por Francisco II, Imperador da Áustria, em 1817, para compor a comitiva nupcial da futura princesa Leopoldina, por onde vieram Spix, Martius e Pohl ${ }^{96}$.

Segundo Lilia Schwarcz (2008), a missão francesa não foi exatamente contratada com antecedência pela Coroa portuguesa, mas sim incorporada aos planos reais após os artistas e suas famílias (cerca de quarenta pessoas) resolverem partir para o Brasil, seduzidos por ofertas de trabalho e pelo vasto campo a explorar, em termos artísticos e naturalistas. O intermédio da negociação se deu com a ajuda do barão de Humboldt, altamente renomado na comunidade científica à época, que creditou Lebreton como pessoa de confiança. Os artistas dessa missão retrataram os membros da Corte e diversas cenas do cotidiano da cidade do Rio de Janeiro e de outras partes do Brasil e foram encarregados do projeto de fundar a Escola Real das Ciências, Artes e Ofícios, transformada, em 1826, na Imperial Academia e Escola de Belas-Artes ${ }^{97}$.

A descrição da "natureza brasílica" "era um dos assuntos preferidos dos viajantes, em sua exuberância, grandeza e diversidade" (Souza, 2003: 617). Neste ponto, uma passagem de Johann Emmanuel Pohl é elucidativa. Depois de fazer uma descrição um tanto desinteressada sobre os costumes sociais na cidade do Rio de Janeiro, o austríaco retoma o entusiasmo quando volta-se à descrição do mundo natural: "passo agora, dessas descrições da vida no Rio, para a esplêndida Natureza e conduzo o leitor ao ar livre, onde tudo reverdeja e cresce viçosamente" (Pohl, 1976: 47).

\footnotetext{
${ }^{95} \mathrm{Na}$ verdade, levavam o mérito sozinhos, pois qualquer viagem da época requisitava acompanhantes para carregar bagagens, conduzir os animais e indicar caminhos.

${ }_{96}$ Os membros da Expedição eram: Mikan, doutor em Medicina e botânico; Pohl, mineralogista e botânico; Natterer, assistente de Zoologia; Schott, real e imperial jardineiro; Raddi, naturalista da Toscana; Spix e Martius, "Reais naturalistas bávaros"; Ender, pintor de paisagens; Buchberger, desenhista de plantas.

${ }^{97}$ Dela faziam parte os pintores Jean-Baptiste Debret e Nicolas Antoine Taunay e seu filho Felix Emille Taunay, os escultores Auguste Marie Taunay, Marc e Zéphirin Ferrez e o arquiteto Grandjean de Montigny, entre outros.
} 
Este intuito correspondia às expectativas do leitor europeu "sedentário" de entrar em contato com o "exótico" e "pitoresco", e de retornar ao idílico, já que o cenário urbano europeu era aquele que se deixava tomar pela recente Revolução Industrial. Desse modo, pode-se afirmar que:

havia um imperativo em explicitar uma paisagem própria ao Brasil entre esses viajantes do início do XIX, que dá, para nossa contemporaneidade, a impressão de que ampliaram o retrato do Brasil, formulando maximamente em sua totalidade tão ambicionada, sobretudo ao conformarem um amplo quadro da natureza em sua completude e unidade, suscitando um efeito sensível agradável no espectador (Souza: 2003: 624).

É bastante rica a produção iconográfica destes viajantes estrangeiros nesta época, e a maioria deles registrou, de alguma forma, a cidade do Rio de Janeiro. Esta aparece como retrato do Brasil, por ser porta de entrada da maioria dos visitantes que adentravam o país. A cidade parecia oferecer o equilíbrio ideal entre uma natureza exótica e a presença humana:

Nas representações paisagísticas do Rio de Janeiro do período em questão [início do século XIX], destaca-se um determinado aspecto: a predominância de uma composição resultado da presença dialética do mar e da montanha como dois grandes elementos temáticos, $[. .$.$] articulados entre si pela arquitetura e a vegetação existentes nos terrenos$ menos acidentados. (Andrade, 2002: 44)

Praticamente todos os relatos de viajantes estrangeiros no período em questão iniciamse pelas bandas do Rio de Janeiro. Eram muito comuns descrições idílicas da baía de Guanabara, por sua beleza natural e também pelo dito "efeito de contraste" para os que chegavam de meses de viagem alimentando os olhos somente com a monótona paisagem marítima. O prussiano von Leithold, escrevendo em fins da década de 1810, comenta a "mágica visão" do porto do Rio de Janeiro, sobre o qual também diz: “...fixei a vista pausadamente, uma vez mais, até onde alcançava, sobre as belezas naturais e confesso que minha pena não seria capaz de lhe fazer justiça, nem mesmo parcialmente" (1966: 9).

Pode-se dizer que, já no início do século XIX, cria-se a imagem do Rio de Janeiro como lugar simbolicamente reluzente, um haut lieu, no imaginário referente ao Brasil. "Produto social feito de pedra e de terra, um lugar é dito ou se torna um 'haut-lieu' em 
função do imaginário que suscita e da simbologia que faz reconhecermos nele". Um haut lieu reúne "sob um objeto, um nome, uma imagem ou uma sensação, uma espessura de sentidos que extrapolam sua materialidade primeira". (Bédard, 2002: 52). No caso do Rio de Janeiro, este haut lieu era a ilustração concreta do vasto território encabeçado pela cidade. "Evocando uma soma de partes e uma trama de escalas espaçotemporais, estamos, em sua companhia, na presença de um lugar supersignificado..." (Bédard, 2002: 52).

As pinturas de paisagem acompanham quase todos os relatos de viajantes, seja na forma de um registro que se propõe mais científico, ou de uma criação artística, que comporta traços mais soltos. Pode-se dizer que a pintura de paisagem vivenciava no início do século XIX uma relação tênue entre arte e ciência, ao transitar entre a necessidade de registro exato e a criação artística e estética. Para Nicolau Sevcenko (1995: 57), "a arte da paisagem nasceu na zona de fronteira entre essas duas forças opostas". Ou seja, “...qualquer que seja seu feitio ou condição, esse ícone [a arte da paisagem] ao mesmo tempo ratifica o rigor da observação direta, 'científica', do artista e proporciona a dimensão evasiva da imagem, sua remissão ao imaginário mítico, seu valor exótico".

Seguindo a idéia propagada pelo método de Humboldt, a descrição minuciosa das espécies coletadas, levada a cabo pelos viajantes, exigia também a contextualização das plantas em seu habitat, em seu entorno, valorizando o recorte da paisagem (enquanto apreensão possível do visível) como recurso explicativo e estético. Esta "superlativa valoração da vegetação tropical como motivo pictórico e as minuciosas e eruditas observações acerca dos diversos tipos de plantas que podem conviver num mesmo ambiente introduziram a criação de uma nova linguagem artística para o registro da natureza de ultramar" (Diener \& Costa, 2002)

Identificam-se, entre esses viajantes estrangeiros, diversos elogios da natureza americana, como no trecho em que Saint-Hilaire (2000: 20) revela que: "nada faz lembrar a fatigante monotonia dos nossos bosques de carvalhos e pinheiros; [pois] cada árvore ostenta, por assim dizer, um porte que lhe é próprio; cada qual tem sua folhagem, que freqüentemente difere do matiz da das arvores vizinhas”. O viajante francês acreditava também que, "para conhecer toda a beleza das florestas tropicais [era] preciso penetrar nesses retiros tão antigos como o mundo", demonstrando que 
discordava da idéia (defendida por Hegel e pelo conde Buffon) de que a natureza do "Novo Mundo" teria se formado posteriormente à do "Velho Mundo", sendo, por isso, inferior.

Os austríacos Spix e Martius (1981, vol. II: 103), em dado momento de sua longa viagem, declaram que a beleza natural do Brasil proporcionava "tanta serenidade de alma, que nos sentimos ricamente compensados da falta do ambiente civilizado". Por fim, o francês Ferdinand Denis, em seu Resumo da história literária do Brasil, de 1825, destacando a magnitude das belezas da América portuguesa, afirma que: "se os poetas dessas regiões fitarem a natureza, se se compenetrarem da grandeza que ela oferece, dentro de poucos anos serão iguais a nós, talvez nossos mestres" (apud Souza, 2003: 624), admitindo a possibilidade, nada convencional, da colônia suplantar a metrópole em termos artísticos.

Para Sérgio Buarque de Holanda (1975: 13, 14), os inúmeros viajantes que desembarcaram no Rio de Janeiro teriam uma papel considerável na criação de uma imagem de Brasil, uma vez que este olhar estrangeiro acabava por levar ao habitante local um ponto de vista ignorado ou esquecido, reavivando um sentimento de pertencimento a um grande país. Em sua obra Viagem pelo Brasil, Spix e Martius relatam que, reunindo material rico e variado, de diversas localidades, sempre apresentavam ao povo seus resultados, comentando que estes eram "alvo de admiração da gente da cidade, que peregrinavam em multidão à nossa casa, para ver as riquezas de sua pátria, tão pouco conhecida deles próprios" (apud Lisboa, 1997: 115).

Para Iara Lis Souza (2003: 606, 607), as coleções desempenhavam um papel importante na formação de um imaginário sobre a natureza de um determinado lugar, uma vez que "traziam para perto algo que estava ausente, concorrendo para a instauração de uma geografia imaginativa do império". Através da reunião de uma série de elementos que, antes dispersos na natureza, passavam a encontrar um sentido e uma ordem nos jardins botânicos ou nos museus, ampliava-se o leque de observadores e transformava-se esta natureza em "patrimônio de um lugar, no caso do Brasil".

É importante destacar que a investigação da natureza "brasílica" já vinha sendo realizada por letrados ligados à burocracia portuguesa, não sendo exclusividade dos 
viajantes estrangeiros a circulação pelo território em expedições científicas. Afinal, nos mesmos caminhos e pontes que se buscavam incrementar na administração joanina, viajavam estrangeiros e os letrados portugueses e brasileiros. Iara Lis Souza (2003) destaca, inclusive, que durante a estadia da corte no Brasil o raio de influência desses letrados brasileiros se estenderia a todo Império português, ajudando na formulação de uma idéia de "poderoso Império" centralizado no Rio de Janeiro.

Além de incluir trânsito entre localidades diferentes, a circulação destes letrados se dava por diferentes instâncias do poder português. As "viagens [de naturalistas contratados pela Coroa] envolviam um circuito e uma sociabilidade que ia do Estado às academias, passava pela universidade e pelos governos locais, pela recepção de memórias remetidas pelos administradores até a Impressão Régia ou seu veto em determinada instância letrada e, ou, burocrática". Pode-se dizer, portanto, que este "trânsito de memórias, objetos, coleções, exploradores, letrados, instruções, que iam e vinham pelos mares, reordenando a compreensão dessa natureza" (Souza, 2003: 612) ajudou a criar, nos moldes das pilgrimage journeys (ou "rotas de peregrinação") de Benedict Anderson (1983), um sentimento de conexão entre os funcionários do governo português.

Para alguns brasileiros ilustrados, tratava-se de "fazer conhecer este continente tão desfigurado por aqueles que, às cegas, ou prevenidos, têm escrito a seu respeito"98, e isso incluía adaptar os conhecimentos e teorias européias à realidade brasileira, tentando perceber as diferenças e as particularidades do mundo tropical. Todavia, os métodos que norteavam este "fazer conhecer" eram ditados pelo espírito cientifico europeu, através, por exemplo, das mencionadas coleções e classificações.

Pode-se depreender, dessas declarações, que no período de estadia da Corte no Brasil gestam-se alguns elementos, e intensificam-se outros, que permitem elaborar uma idéia de pertencimento a um grande país, ou, mais ainda, a um "grande Império", em que a identidade seria portuguesa, mas a base material americana e tropical. E seria a partir das possibilidades reais do território da América portuguesa que se passam a projetar diferentes concepções políticas que entram em jogo nos acontecimentos de 1821-1822 (Dias, 2005).

\footnotetext{
98 "Notícia das novas povoações de São Pedro de Alcântara e São Fernando, civilização da nação Macamecran na estrada para o Pará". O Patriota, n.3, setembro de 1813, p. 61. (Apud Dias, 2005: 73).
} 
Para Maria Odila Dias (2005), esse conhecimento construído a partir do fim do século XVIII representava os instrumentos de que dispunham os homens do período da Independência para manejar a realidade de sua terra. A partir do intuito de conhecer as potencialidades naturais da América portuguesa derivou-se um projeto de nação, no qual os problemas sociais também passam a ser discutidos.

\subsection{Porto e porta: entradas e saídas}

Inserido num contexto de abertura, evidentemente que ainda não imune à censura, o Brasil intensificava contatos com mercadorias, idéias e pessoas de várias partes do mundo. E o Rio de Janeiro era a porta de entrada (e saída) deste trânsito.

Quando a vila de São Sebastião do Rio de Janeiro foi elevada à condição de cidade, ela já podia ser considerada um bom ancoradouro, pelas suas águas profundas e relevo montanhoso, que garantiam atracação e proteção, tornando-se ponto de parada para embarcações da rota do Atlântico sul e das Índias. Um século depois, quando descobertas de ouro no sertão motivavam abertura de caminhos e expedições, a relativa importância dessa cidade na porção meridional da colônia a tornaria porto escoador da economia aurífera, consolidando-se como capital do Vice-Reino do Brasil em 1763.

Desde que o Rio de Janeiro se tornou o porto escoador da produção da Minas, o espaço apropriado da capitania cresceu muito, assim como sua capital, cuja população aumentaria de quatro mil habitantes (no início do século XVIII) para cerca $43 \mathrm{mil} \mathrm{em}$ 1799, segundo dados de Afonso Arinos de Mello Franco ${ }^{99}$.

O século XVIII seria decisivo na constituição do Rio de Janeiro como principal porto da América portuguesa, alcançando uma vasta hinterlândia, que articulava redes marítimas e terrestres, ligadas ao comércio de produtos do Oriente e da Europa, tráfico de ao escravos e ao comércio de abastecimento.

\footnotetext{
99 Apud Francisco J. C. Fálcon \& Ilmar R. Mattos, "O Processo de Independência no Rio de Janeiro". In: Carlos G. Mota, 1822: Dimensões. São Paulo, Ed. Perspectiva, 1972.
} 
Após 1808, há uma mudança qualitativa e quantitativa nas relações de troca deste porto que possuía funções múltiplas, conforme atesta Corcino Santos (1980), sendo ao mesmo tempo "distribuidor, recolhedor, redistribuidor, consumidor e varadouro [...], portotrânsito, e de tráfego de passageiros".

Daí o papel articulador do Rio de Janeiro entre o interior da colônia e as redes marítimas, principalmente após a vinda da Corte portuguesa, quando se passa a ter uma política deliberada de ligação das diferentes capitanias da América portuguesa. Lentamente, a cidade do Rio de Janeiro:

passava à condição de ponto de encontro de diferentes rotas de comércio interno (leiamse mercado interno e acumulações dele derivadas), a constituir-se em entreposto fundamental na redistribuição de produtos importados e a principal porto de exportação de produtos coloniais (Florentino \& Fragoso, 2001: 85).

Para se compreender o Rio de Janeiro do início do século XIX é necessário ter em mente a diversidade de condicionantes que atuavam em seu contexto de porto centralizador. Uma face atlântica, que contemplava desde comércio com Europa, África e Ásia, até a navegação de cabotagem; uma face terrestre, que se interiorizava cada vez mais, recriando o sistema agrário-exportador, com o café, mas gerando, para sua perpetuação, outras formas de produção e um mercado interno que possibilitou inclusive a realização de acumulações endógenas, no âmbito da própria colônia.

Como vimos, a partir da instalação da Corte portuguesa na cidade se constrói uma estreita aliança entre a monarquia e a elite local carioca, com interesses que se conjugam numa ampla rede de negócios que extrapola a produção e envolve a Europa, a Ásia e a África, assim como as Minas Gerais, Goiás, Mato Grosso, São Paulo, Rio Grande de São Pedro. Pode-se dizer que se forma uma região econômica no Centro-sul, com o pólo principal no Rio de Janeiro, sendo esta região o primeiro exemplo de mercado interno, se seguirmos a acepção de Karl Polanyi.

Para este autor, "o comércio local é limitado às mercadorias da região, as quais não compensa transportar porque são demasiado pesadas, volumosas ou perecíveis" (Polanyi, 2000: 78) ou seja, seria este tipo de comércio, afetado pela distância 
geográfica, que nortearia a conexão dos núcleos produtivos com os portos e localidades produtoras de alimentos até o advento da mineração. Tratava-se de comércio simplesmente complementar, o que, para Polanyi, também caracterizaria a troca entre países diferentes por gêneros não produzidos em seu interior. "Um comércio desse tipo [local] é descrito corretamente como complementar. A troca local entre cidade e campo e o comércio exterior entre diferentes zonas climáticas baseiam-se neste princípio. Um tal comércio não implica competição necessariamente, e se a competição levasse à desorganização do comércio não haveria contradição em eliminá-la" (Polanyi, 2000: $80)$.

Já o comércio interno, por sua vez, seria "essencialmente competitivo", por incluir um número muito maior de trocas, inclusive de mercadorias similares, provenientes de diferentes fontes e oferecidas em competição. Segundo Polanyi (2000: 81), este mercado interno, que conecta longas distâncias com competição entre mercadores, é essencialmente territorial e seria a base do comércio nacional, por sua vez articulador de várias "regiões".

Estas colocações nos remetem às formulações de Walter Christaller sobre os "lugares centrais". Apesar de estar pensando sobre a realidade alemã, o modelo criado pelo autor é interessante para a reflexão sobre a emergência de um pólo, no bojo de uma rede de comércio e serviços. Christaller acredita que os assentamentos humanos são configurados em uma relação hierárquica regular uns com os outros e propõe uma teoria dedutiva para explicar o tamanho e a distribuição das cidades em termos de tipos de serviços que elas dispõem à hinterlândia ao redor (Eufrásio, 1982) ${ }^{100}$.

Localidades que são consideradas "lugares centrais" têm uma concentração de fornecedores de produtos e serviços. O tamanho de suas respectivas "hinterlândias mercantis" é determinado pelo mínimo peso econômico de atividades de suprimento e pela máxima demanda de bens. Para cada importante lugar central, que disponibiliza uma ampla gama de funções básicas e especializadas, Christaller identificou a existência de numerosos pequenos estabelecimentos próximos uns dos outros que apenas produzem funções básicas, de ordem menor, como a produção de alimentos perecíveis

\footnotetext{
${ }^{100}$ A dissertação em questão contém tradução do original de Walter Christaller, "Die zentrale Orte in Süddeutschland" - o Lugar Central no sul da Alemanha - de 1933.
} 
que não podem ser transportados a longas distâncias, ficando reduzidos a um curto raio de circulação (Eufrásio, 1982).

Ou seja, quanto mais serviços e produtos uma localidade central oferece, em meio a uma série de localidades de pequeno porte, maior passa a ser seu raio de influência, condição necessária para a formação de um mercado interno, que ultrapasse as pequenas distâncias geográficas. A teoria de Christaller, entretanto, se mostra um tanto insuficiente para pensar a realidade colonial, visto que o autor se reporta somente às implicações endógenas da formação de uma hierarquia de lugares.

Claude Raffestin (1980: 169) critica a visão demasiadamente sistêmica de teorias como a de Christaller. Para ele, a centralidade:

não é esta noção pura geométrica que os homens teriam inventado ou descoberto. Ela é uma outra coisa. Ela é primeiramente a existência de uma coletividade unida por ações, criadora de relações, que fundam diferenças específicas. O lugar, sem estas relações, não é nada além de um lugar entre outros.

Conforme colocado no capítulo II desta dissertação, Raffestin (1980) acredita que a centralidade expressa tanto um "topos" quanto uma "tensão", uma vez que sua construção implica na violência e no ocultamento das rejeições necessárias à consolidação de um centro. Pois toda centralidade pressupõe também uma marginalidade, sendo estas categorias relacionais, definidas partir uma da outra. Como exemplo, temos que metrópole e colônia se constituíam numa relação, sendo essenciais à existência uma da outra, mas uma relação pautada pela "regra da diferença" (Hall, 2002), ou seja, em que os diferentes papéis sustentavam-se a partir do gap que definia uma como centro e outra como periferia (ou margem).

Refletindo sobre a situação colonial da América do Norte, James E. Vance Jr (1970) considera necessário articular condicionantes endógenas e exógenas para entender a dinâmica das centralidades criadas sob estas condições, uma vez que a produção das colônias era essencialmente voltada para o mercado externo. O autor destaca que, no sistema mercantil, as relações comerciais de longa distância formam assentamentos que inicialmente têm a função de entrepostos comerciais. Com o tempo, estes assentamentos vão engendrando uma rede local de abastecimento, e se transformam em "pontos de 
conexão". Assim, os assentamentos mais bem sucedidos se estabelecem como centros comerciais, com sua própria hinterlândia, seguindo hierarquias semelhantes às da teoria dos lugares centrais.

O modelo voltado para a exportação gera hierarquias urbanas assimétricas, em que centros de ordem menor têm função similar aos outros, pois também servem como pontos de produção para exportação e concentração de capital mercantil (Vance Jr, 1970).

No caso do Rio de Janeiro, é importante destacar o papel da política da metrópole em restringir a exportação do ouro extraído nas regiões mineradoras a seu porto. Se a cidade já apresentava certa relevância comercial, a partir deste fato impulsiona-se a formação de um pólo, um lugar central no topo da hierarquia, o que não se dá "naturalmente", mas juntamente com uma clara política de concentração, para facilitar o controle de tão preciosas mercadorias. Aqui também podemos lembrar as reflexões de Raffestin (1980) e Hall (2002), colocadas acima, uma vez que a eleição de um ponto como centralidade acaba marginalizando outras áreas (como foi o caso dos "sertões proibidos").

Para Russel-Wood (1998) um "centro" ou "núcleo", associado sempre a um aglomerado urbano, seria uma vila ou cidade capaz de cumprir um papel multifuncional enquanto centro de governo, bispado, comércio, ou de importância estratégico-militar, entre outras. Wood evoca os conceitos de "umland", "hinterland" e "vorland" para explicar as possíveis relações entre os núcleos constituídos e suas áreas de influência. Estes conceitos são interessantes para se pensar a centralidade econômica do Rio de Janeiro, pois permitem refletir sobre as áreas de influência contíguas territorialmente (hinterland e umland), mas também sobre as áreas que não apresentam contigüidade com o centro da rede, como por exemplo os portos africanos que negociavam intensamente com o Rio de Janeiro (vorland).

Para Eugene Von Cleef (1941), a umland de uma cidade é a área imediatamente adjacente a seus limites políticos, sendo uma parte da hinterlândia contínua. Geralmente 
na umland estão incluídos os subúrbios da cidade em questão. Já a hinterlândia compreenderia uma região mais extensa, incluindo as cidades "satélites" e as localidades que são ligadas econômica e culturalmente ao centro principal.

A idéia de vorland (ou foreland, em inglês) vem geralmente associada à extensão da hinterlândia para o além-mar, ou seja, localidades que possuem estreita ligação com o centro principal, mas que não se encontram contiguamente articuladas a ele. Muitos geógrafos, como Guido Weigend (1956: 3), por exemplo, consideram que a 'foreland' de um porto inclui todas as áreas conectadas a ele através de rotas oceânicas.

Na sessão "Notícias Marítimas" da Gazeta do Rio de Janeiro, percebem-se as localidades que tinham contato com o porto do Rio de Janeiro, seja pelas "entradas" ou pelas "sahidas" de embarcações. Em "mappa" (tabela) publicado no dia 01/01/1812, listam-se as embarcações que entraram neste porto no ano de 1811, com os seguintes destaques internacionais, a partir do local de proveniência: Inglaterra, com 57 embarcações, África, com 54, Portugal, com 40 e Estados Unidos com 32. Montevidéu e Buenos Aires, totalizavam 70 embarcações (sendo 22 delas de pequeno porte: lanchas, sumacas e escunas). No comércio de cabotagem, também contemplado por embarcações menores, as origens mais recorrentes são: Rio Grande e Campos, ambos com 179 embarcações (sendo as provenientes de Campos de menor porte), seguidos de Bahia e Pernambuco, que somam 80, Ilha Grande, 58 e Santa Catarina, 51 embarcações.

As mercadorias eram das mais variadas: açúcar, aguardente e gêneros alimentícios da capitania do Rio de Janeiro, madeiras, couros, sebo dos portos do sul e do Prata, "gêneros de Inglaterra", ou gêneros variados de Inglaterra, fazendas, manteiga, bacalhau e azeite de Portugal, escravos, sebo e marfim da África. Dos navios dos Estados Unidos, vinham gêneros como vinho ou escravos, ou seja, produções de outros lugares, intermediadas por estes comerciantes. Na Gazeta também se anunciavam as partidas mensais de embarcações para outros portos, o que sugere que era intenso o fluxo de pessoas em trânsito nas rotas marítimas.

Seria justamente através do porto do Rio de Janeiro que chegaria, em 1815, um presente um tanto curioso para o príncipe regente: um portão de ferro, cópia quase idêntica do 
portão que adornava entrada do Syon Park de Londres, que o príncipe regente havia visto num esboço e desejado para a entrada de sua casa de campo, a Quinta da Boa Vista. Uma réplica do portão havia sido solicitada pelo embaixador inglês em Portugal, Lord Strangford, ao segundo duque de Northumberland, através de uma carta recebida por este em 19 de agosto de 1810. O segundo duque de Northumberland havia estado em Portugal por razões de saúde entre 1792 e 1794 e nutria pelo país e seus habitantes uma forte afeição. Na carta, Strangford pedia ao duque que se encarregasse dos preparativos para a fabricação do portão:

O Principe Regente está imensamente desejoso de obter dois portões de ferro para a Residência de campo que possui a 5 milhas de seu palácio, e sua fantasia foi tão cativada por um esboço que ele havia visto do portão mais belo que forma a entrada do Syon Park que me designou a mencionar a sua Graça o quão agradecido ele se sentiria se sua Graça ordenasse o mesmo artista a fazer dois portões muito menores em tamanho mas no mesmo estilo, endereçando-os quando terminados à conta do 'Chevalier de Souza'. Acredito que a largura de cada portão deve ter aproximadamente 30 pés. As Armas Reais de Portugal também devem ser inseridas na parte ornamental ${ }^{101}$.

Se inicialmente a carta dizia que as despesas seriam pagas pelo Cavaleiro de Souza, em outra carta, escrita pelo Conde de Funchal na sequência, e também endereçada ao duque, agradecia-se a ele pelo magnífico presente (Kelly, 1984). Dois anos depois, chegava ao Rio de Janeiro, depois de cruzar o Atlântico no navio Betsie, o artesão encarregado da fabricação da réplica, trazendo o pesado presente, custeado, ao final, inteiramente pelo duque de Northumberland. Apenas em 1815 finalizou-se a instalação do portão, visando embelezar a entrada do palácio real.

John Luccock, ao descrever o palácio, diz: "à frente dele acha-se um portão que à Sua Alteza Real enviou o Duque de Northumberland, cópia exata do que dá acesso à 'Sion House', mas que aqui constitui uma singular espécime de incongruência" (1975: 176). Talvez, para o viajante inglês, ver um simulacro de um objeto que lhe era familiar colocado em outro contexto, em terras tropicais, fosse um tanto estranho, talvez fora de lugar.

Já o viajante Johann Pohl nos presenteia com um detalhe interessante:

101 Carta de Lord Strangford para o segundo duque de Northumberland. Percy Family Letters, 66. Northumberland Archives. Apud Kelly, 1984. 
Este Palácio de verão, que é chamado também São Cristóvão (do nome de uma aldeia próxima), acha-se dentro de um parque, sobre uma colina baixa, mas isolada, cujo planalto nos dá a magnífica vista da capital. O grande portão é um presente, para aqui vindo da Inglaterra. Foi porém tão inconvenientemente colocado, num muro a pique sobre uma ladeira da colina, que apenas serve de ornato e não de verdadeira entrada. Esta se faz por uma abertura lateral, murada, no castelo (1976: 54).

Figura 12. Portão do Palácio de São Cristóvão

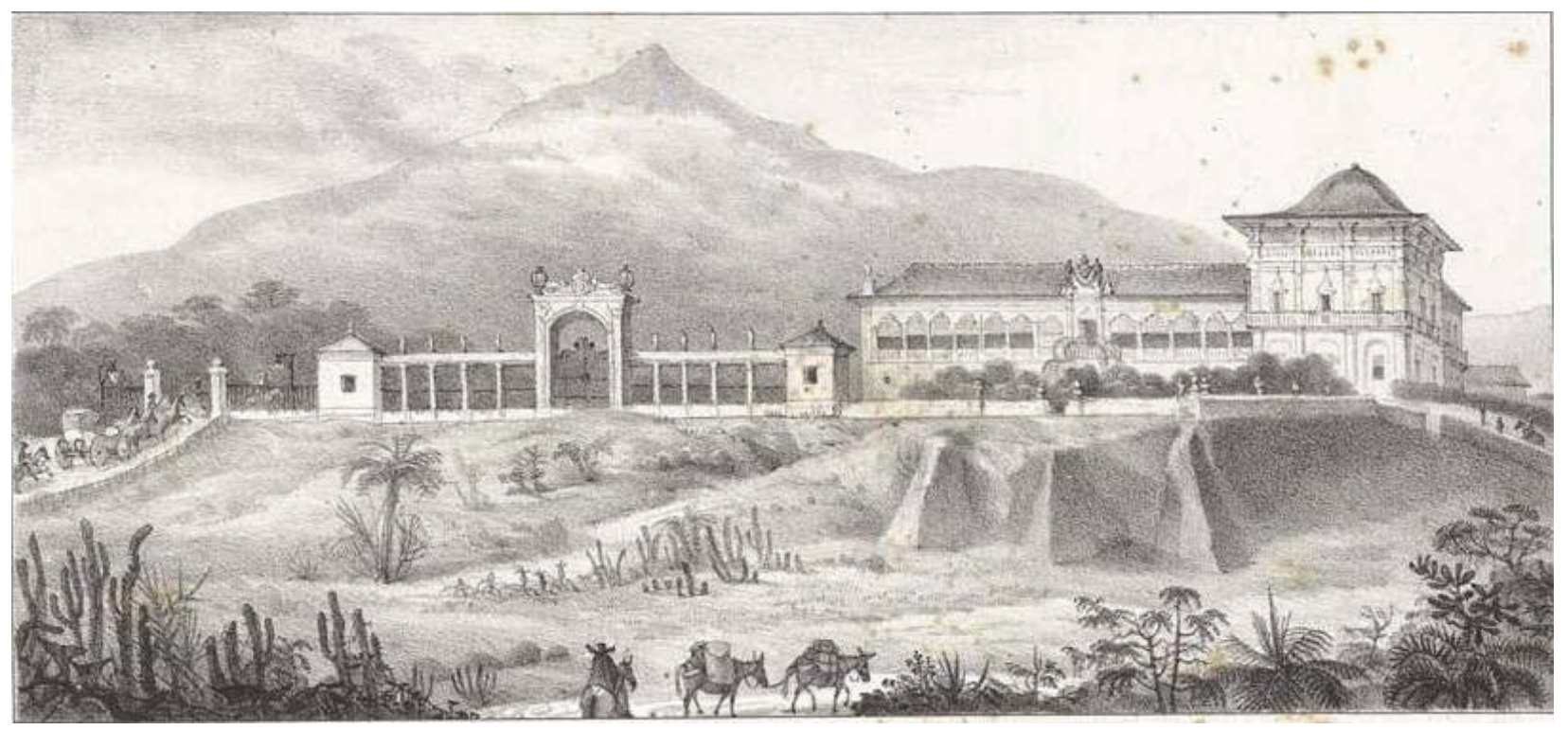

Debret, Jean Baptiste. “Améliorations progressives du palais de St Christophe” Biblioteca Nacional Digital. 
Ou seja, afinal, o portão importado da Inglaterra não servia de "verdadeira entrada" e sim de enfeite, simulacro de porta, prestando-se somente ao serviço de enobrecer a construção com falta de requinte. A porta não servia nem para abrir nem para fechar, mas era estática. Esta metáfora nos faz refletir sobre a situação do porto enquanto "porta", questionando o que de fato entrava e saía, além de produtos e pessoas. Será que o porto do Rio de Janeiro se abrira também às novas idéias européias?

Conforme trabalhamos no capítulo II, houve um imperativo da política joanina de "abrir as portas do sertão", seja no caso dos Sertões do Macacu, examinado mais de perto neste trabalho, seja no do sertão do rio Doce, por exemplo. Quanto ao porto, o direcionamento era filtrar ao máximo as informações e idéias perigosas que pudessem abalar a legitimidade da monarquia ${ }^{102}$.

Se pela "porta" do porto não passavam indistintamente variadas mercadorias, censurando-se livros e periódicos ditos "revolucionários", ao mesmo tempo era difícil conter a propagação destas idéias, que bem ou mal acabavam chegando às rodas de conversa, panfletos e mentes.

Kirsten Schultz (2006: 147) argumenta que houve, da parte da Coroa, uma habilidade em lidar com as novas idéias, subvertendo-as para a realização de algumas continuidades:

Mais do que uma simples reação à revolução, os modos pelos quais os funcionários e vassalos reais definiram o sentido da monarquia e do império depois de 1807 abriram possibilidade de uma transição da colônia para o império baseada em continuidades e tradições políticas e institucionais, mesmo que eles desafiassem aquelas instituições e tradições e, ao fim e ao cabo, mudassem seus sentidos.

Para a autora (Schultz, 2000), a vinda da corte portuguesa para o Rio ocasionou uma equalização da vassalagem, assim como uma inversão na ordem estabelecida entre metrópole e colônia, justamente numa época em que a política e as identidades políticas se redefiniam com apelos aos princípios universais da liberdade e da igualdade, e ao

${ }^{102}$ Se o Rio de Janeiro era descrito, em 1765, por d. Luiz de Antonio de Souza, como "a chave deste Brasil, pela sua situação", (apud Bicalho, 2006: 2) podemos dizer que, durante o período joanino, ele afirma seu papel de "chave" ao concentrar o controle político do que podia passar ou não pela porta de entrada do porto. 
exercício da soberania popular. A resolução dessa contradição entre tradição e inovação encontrou-se no ideal de uma renovação do poder real e imperial no novo mundo e numa reclamação dos direitos dos "vassalos", ambos baseados no fim do chamado "antigo sistema colonial".

Para Souza (1998) essas mudanças acabaram refletindo numa transformação qualitativa da idéia de rei, que passa pela revisão do caráter absoluto da figura do monarca e culmina, ainda que não com a revogação da forma monárquica de governo, mas com a sua forma constitucional aparecendo como essencial. Se, pela treliça porosa das janelas fechadas entravam alguns raios de luz, pela porta do porto também passavam novos ventos, que podiam ser contornados de acordo com um ímpeto de conservação, mas não barrados.

Sobre este ponto, vale a pena resgatar a reflexão de Jean Gottman sobre movimento e resistência. Para este geógrafo, a circulação de homens e seus produtos é a grande dinâmica da sociedade e um dos temas mais apaixonantes em geografia: "o fato fundamental do nosso universo é que ele se move, que tudo nele é movimento, fluidez: a atmosfera, as águas, os homens, o pensamento. É por isso que a circulação está na base de toda geografia e de toda política" (Gottmann, 1952: 120).

Para este geógrafo, existem "sistemas de movimento", que formam tudo o que chamamos de circulação no espaço, e também sistemas de resistência ao movimento, os quais denomina "iconografias". Estas seriam mais abstratas do que materiais, consistindo em um determinado número de símbolos (Gottman, 1952: 214, 215). A circulação, ao mover as coisas de lugar, acaba tendo uma função transformadora, seja ao criar um circuito de troca, ou ao efetuar uma transferência em sentido único.

O interessante é que a mobilização, por parte dos atores sociais, da "iconografia" utiliza a circulação a fim de estabelecer e reforçar sua autoridade, assim como "os sistemas de movimento" acabam transformando a iconografia, conforme vão se estendendo pelos lugares. No caso do Rio de Janeiro, a presença da monarquia em solo americano tinha um duplo condicionamento, pois, ao reforçar a ponte de contato com a Europa, ocasionava o aumento do trânsito tanto de idéias favoráveis ao absolutismo quanto 
daquelas contrárias a ele. Como dizia Heliodoro Araújo Carneiro "o Brasil abrio os olhos e forão os mesmos Portuguezes que contribuirão para isto"103.

${ }^{103}$ Heliodoro Jacinto Araújo Carneiro. Brasil e Portugal, ou reflecções sobre o estado actual do Brasil. Rio de Janeiro, Typographia do Diario, 1822. Bibioteca Nacional do Rio de Janeiro, Seção de Obras Raras, $(39,8,10)$. 


\section{APONTAMENTOS FINAIS}

Ao invés de iniciarmos esta dissertação com teorizações sobre o que entendemos por 'território' ou 'centralidade', optamos por desenvolver, ao longo do texto, as relações entre a realidade estudada e os conceitos que se fazem sobre ela. Esta relação muda conforme avança o correr do tempo, num movimento constante de desenhos e redesenhos. A idéia de território, por exemplo, tem que ser compreendida neste movimento. A historicização do conceito leva a perceber que o território estatalnacional, tal como conhecemos hoje, é fruto de um processo gradual de afirmação de um poder soberano por um Estado, a partir de um controle administrativo e militar de um espaço contínuo, conforme descrito por Paul Alliés (1980).

Definido como se como jurisdição de um poder, numa perspectiva compartilhada pela geografia política clássica, o território é uma unidade política. De acordo com Jean Gottmann (1952: 31):

Quer seja o todo do território nacional de um Estado, ou mesmo o conjunto das terras agrupadas em uma unidade que depende de uma autoridade comum e possui um dado regime, o território é um compartimento de espaço politicamente distinto daqueles que o rodeiam.

Inseridas numa perspectiva que pensa o território como espaço de exercício de um poder, se encontram as ponderações de Robert Sack (1986), para quem o território é uma área de acesso controlado, que pressupõe a definição de fronteiras. Por ser delimitado, o território muitas vezes é associado a um compartimento fechado e horizontal, em oposição ao das redes, que seriam verticais e fluidas. Rogério Haesbaert discute essa suposta dicotomia (2006), tentando quebrar esse estigma e formular a idéia do "território-rede", ao pensar sobre a compressão espaço-temporal contemporânea. Para ele:

Talvez seja esta a grande novidade da nossa experiência espaço-temporal dita pósmoderna, onde controlar o espaço indispensável à nossa reprodução social não significa (apenas) controlar áreas e definir "fronteiras", mas, sobretudo, viver em redes, onde nossas próprias identificações e referencias espaço-simbólicas são feitas não apenas no 
enraizamento e na (sempre relativa) estabilidade, mas na própria mobilidade (Haesbaert, 2006: 279).

Ao refletirmos sobre a territorialidade vigente no Antigo Regime, fundada em princípios dinásticos, entretanto, percebemos que a fluidez fazia parte da idéia de território, e que justamente uma série de "redes" sustentavam essa coesão. Logicamente que as redes contemporâneas se valem da evolução técnica e informacional para proporcionarem uma velocidade excepcional de trânsito, ou mesmo a instantaneidade, o que era impensável numa época movida pelos passos lentos de mulas e cavalos e pelo soprar do vento sobre as velas das naus.

De qualquer modo, de acordo com Alain Bourdin:

Sempre houve territórios descontínuos, os dos comerciantes e seus balcões, os das peregrinações e de suas igrejas de romaria, "territórios-rede" de que o Império de Veneza oferece uma perfeita ilustração. Hoje, este tipo de território domina, dando um outro significado aos recortes tradicionais, sobretudo políticos. (Apud Haesbaert, 2006: 280)

Conforme já colocado, o território, segundo Benno Teschke (2002) não constituía a base da soberania dinástica, sendo somente uma propriedade adjunta da dinastia vigente. Assim, os territórios pertencentes a um mesmo soberano poderiam estar dispersos pelo globo, regidos por leis que se moldavam aos contextos locais. Para Iara Lis Schiavinatto, a centralidade encarnada pela corte "comunicava-se com todas as localidades, numa espécie de atributo universal, produzia relações de dominação e presumia certa maleabilidade para enfrentar o conflito e a negociação, assegurando a coesão do império" (2006: 210).

Por ser descontínuo, o território dinástico talvez possa ser entendido pela idéia de rede, pois diferentes territórios eram conectados por redes administrativas, militares, mercantis. Segundo Bakis (1993), o próprio território estatal nacional seria territóriorede, uma vez que estruturado por diversas redes.

A passagem do século XVIII para o XIX representa um período de ebulição, de abalo da legitimidade dinástica, que tem consequências profundas para a América colonizada. 
Gradualmente, este território disperso e descontínuo, antes associado à figura do soberano, passa a ser delimitado por fronteiras cada vez mais rígidas, que se sustentam em função de algum tipo de acordo político entre os habitantes desta porção de terra.

Temos, no início do século XIX, a coexistência tanto de uma idéia de territorialidade vinculada ao Antigo Regime, como de um nascente questionamento da soberania dinástica. Na América hispânica, por exemplo, lê-se, na Gazeta de Montevideo, o trecho “...la conservación de la integridad territorial [es] uno de los primeros deberes del vasallaje" ${ }^{104}$. Percebe-se que a integridade do território do monarca dependia da fidelidade do vassalo, não importando a contigüidade territorial. Em Buenos Aires, por sua vez, já se pensava em soberania popular (com todas as restrições que isso representava na época) e formava-se uma concepção de território que ia se dissociando daquela do Antigo Regime, como pode ser apreendido pelo seguinte trecho:

Pueden pues las provincias obrar por sí solas su constitución y arreglo, deben hacerlo porque la naturaleza misma les ha prefijado esta conducta, en las producciones y limites de sus respectivos territorios; y todo empeño, que les desvíe de este camino es un lazo, con que se pretende paralizar el entusiasmo de los pueblos hasta lograr ocasión de darles un nuevo señor ${ }^{105}$

Forma-se um novo tipo de pensamento que associa a soberania com a constituição elaborada pelas próprias províncias, em seu próprio território. Apesar de parecer que um novo conceito de nação também se delineia, trazendo um elemento da etimologia desse termo, o natio, de nascer, de acordo com João Paulo Pimenta (2002), em sua análise dos periódicos da época, o termo nação ainda estava em muito atrelado com a nação colonizadora (Portugal ou Espanha), seja em Montevidéu e no Rio de Janeiro, e até em Buenos Aires, mesmo sendo sua Gazeta a principal porta-voz de uma política revolucionária no Prata.

Todavia, na seguinte citação de José Carlos Chiaramonte, no próprio Regulamento de Divisão de Poderes de 1811, feito pela Junta de governo portenha do "Primero Triunvirato", a questão da confederação política como um acordo feito entre os nascidos em mesmo território é clara, mesmo que não se fale ainda numa nação: “...para que una

\footnotetext{
${ }^{104}$ Gazeta de Montevideo, extra no 37 de 31/8/1811. (apud Pimenta, 2002: 85)

${ }^{105}$ Gazeta de Buenos Aires, no 27 de 6/12/1810. (apud Pimenta, 2002: 94)
} 
autoridad sea legítima entre las ciudades de nuestra confederación política debe nacer

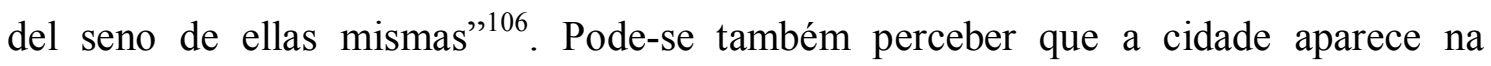
qualidade de corpo político principal, como se não houvesse nada além do que centros urbanos no território a fazer parte da Confederação.

Segundo o referido autor, as cidades eram as entidades efetivamente soberanas naquela época, criando uma "regionalidade freqüentemente reduzida ao seu núcleo urbano" (Chiaramonte, 1997: 75). Para Bertrand Badie, a cidade na História estabeleceu uma ligação direta entre urbe e território, pois ela que inaugurou a idéia de soberania territorial, tendo muitas vezes suas fronteiras bem delimitadas por muralhas. A cidade “inicia indubitavelmente a formação de uma comunidade política” (Badie, 1996: 19).

As ruas e as janelas da cidade revelam todos os tipos existentes em determinada sociedade, dos mais estabelecidos aos marginalizados. É também na cidade que se encontram os fluxos das redes (econômicas, políticas, culturais) que sustentam sua centralidade enquanto lugar de troca, comunidade política, ponto de importância simbólica. A existência de diversas redes materiais ligando variados interesses no próprio território luso-americano teve um papel fundamental na elaboração de um projeto político, centralizado no Rio de Janeiro, que tinha na manutenção da integridade territorial um de seus principais alicerces, assim como na continuidade da escravidão.

Ilmar Mattos (2005) ressalta que o projeto hegemônico de construção política do Brasil se realizaria como condição para a preservação de uma herança. Antes de construtores, os protagonistas desse projeto eram, primeiramente, herdeiros de um nome e de um território. Nisso se destacam discursos, como os de José Bonifácio, em que a conservação da integridade territorial - a principal herança - se coloca como alta prioridade $^{107}$. Para Mattos, a herança territorialista teria se mantido após a Independência política da América portuguesa, e, mais que isso, teria tido papel fundamental na constituição do Império, sob o qual os ímpetos expansionistas se mantiveram na ordem do dia. Ou seja, seria a partir do território, enquanto principal

\footnotetext{
${ }^{106}$ Introdución al Reglamento de la División de Poderes, setembro de 1811, (apud Chiaramonte, 1997: 121, íntegra do documento na p. 349)

107 “... preguei a Independência e Monarquia Constitucional, único sistema que poderia conservar unida e sólida esta peça majestosa e inteiriça de arquitetura social desde o Prata até o Amazonas, qual a formara a mão onipotente e sábia da Divindade". Carta dirigida ao Imperador, 1823. "O Tamoio", edição de 2 de setembro de 1823. (apud Mattos, 2005).
} 
herança, que a construção da nação se daria, sendo o povoamento, dentro dessa perspectiva, uma das diretrizes básicas de uma organização política que se faria também por outra continuidade: a monarquia.

Entretanto, a afirmação de certas heranças não se deu facilmente. Buscou-se propagar uma imagem de coesão do Império português, porém alguns acontecimentos, como a Revolução de 1817 e depois o próprio movimento constitucionalista do Porto, demonstraram a fragilidade da união luso-brasileira.

Em Recife, cidade proeminente na porção norte do que era o Brasil, se inicia o movimento que uniu padres, negociantes, pequenos sitiantes, homens livres, boticários, todos opostos ao aumento dos tributos desde a instalação da corte. Estendendo-se a Paraíba, Ceará e Rio Grande do Norte, a Revolução de 1817, através de seus atores, formula uma concepção de soberania pautada no povo, em que "não havia lugar para o rei" (Souza, 1998: 69). Denis Bernardes (2002: 205) qualifica o momento como a "mais ousada e radical tentativa de enfrentamento até então vivido pela monarquia portuguesa em toda sua história". Neste momento "uma parte importante da monarquia funda uma outra soberania e lança-se no crime de separar-se do corpo do Rei, de não ser mais, simbólica e praticamente, parte dele, em solo então marcado pela presença da Corte e elevado à categoria de Reino Unido. Numa acepção um tanto exagerada, crê que, se não chegam a rolar cabeças, literalmente, "o corpo da Nação estava sendo cortado e negada a unidade que tinha na pessoa real a sua cabeça e símbolo" (Bernardes, 2002: 206).

Mas se a presença da pessoa real nas Américas pode ter acirrado as disputas regionais, por outro lado acabou vinculando o rei ao território colonial, através da sua interiorização na região centralizada pelo Rio de Janeiro, fortalecendo a monarquia nos trópicos. A dificuldade em sustentar o laço de vassalagem a um rei distante, em épocas de idéias revolucionárias, pôde ser minimizada pela construção de uma nova relação, que reafirmava a tradição da monarquia portuguesa em novo terreno americano, visto como lócus repleto de potencialidades e de um glorioso futuro.

Tanto que a verdadeira ruptura viria de fora, da parte que havia ficado marginalizada no todo demasiado extenso que era o Império português. Ao longo do período joanino no Rio de Janeiro, eram comuns os questionamentos sobre a localização do soberano, 
prevendo-se a impossibilidade deste governar a totalidade imperial por muito tempo a partir da ex-colônia. Essa questão do lugar onde deveria residir o poder se colocava tanto para os ilustrados fiéis à Coroa quanto para aqueles críticos ao absolutismo.

O deputado Silvestre Pinheiro Ferreira, por exemplo, escrevendo em 1815, após a queda de Napoleão, perguntava-se: qual o lugar, a fonte de poder? Onde o rei residiria e instalaria sua corte? Enfim, onde localizar a soberania? (Souza, 1998). O filósofo temia uma revolta em Portugal, pela sensação de inversão de papéis e o sentimento de orfandade que havia se instalado sobre a antiga capital. Como solução, chegou a pensar na instalação de duas cortes, uma em Lisboa e outra no Rio de Janeiro. Entre os homens ligados ao governo de d. João VI, buscava-se instaurar uma "rede de poder no império que o estruturasse e o hierarquizasse de maneira uniformizada, procurando amenizar as discrepâncias entre seus diversos interesses" (Souza, 1998: 56).

O matemático Antonio D’Oliva Sousa Sequeira, afirma, em 1821, a necessidade de estabelecer um "centro comum" no Império português, não deixando dúvidas de que o local adequado seria o Rio de Janeiro:

He hoje sem duvida que os nossos Illustres Legisladores, occupados em lançar bronzeados alicerces a um grande futuro, devem alargar as suas vistas pelas vastas descobertas desses heróicos Portuguezes nossos passados, e traçar tão sabias linhas, que venhão a reunir em um centro comum o producto de tantos trabalhos o cimento de tanta gloria. Qual deva ser este centro, a perspectiva do grande quadro Portuguez o está mostrando, a simples vista de um mappa nol-o indica.

Já Heliodoro Jacinto de Araújo Carneiro reflete, em 1822, pouco antes da independência, sobre a impossibilidade de manter um centro comum, vistos os acontecimentos da corte. Seus escritos trazem alguns aportes para pensar os legados da estadia joanina no Rio de Janeiro. Formado em Medicina em Coimbra e amigo de Hipólito José da Costa, Carneiro argumentava o seguinte:

Que monstruosidade em Politica não seria as Provincias do Brasil confederarem-se e terem seu ponto de reunião na Europa: e que sangue não hia a correr com estes outros tantos Reinos estabelecidos de facto! [...] Não pode existir unidade e firmeza de Governo, sem que haja hum ponto de apoio e de reunião o mais proximo destas partes 
constituintes. O Brasil deve fazer por força parte do Systema Politico da America e não do Systema Politico da Europa. Já lá vai o Systema colonial. ${ }^{108}$

Nota-se, na posição de Carneiro, uma associação da pátria ao território - este por sua vez visto como patrimônio, de enorme importância para a nação. Diz ele, em reposta ao argumento de alguns deputados portugueses que preferiam perder "mil Brasis" à dignidade:

Quando se trata de perder ou conservar parte da nossa Patria, do Territorio, que constitue não só o nosso Patrimonio, mas o da nossa posteridade, não há dignidade a ganhar, quando aquilo se perde. Que dignidade podemos nós conservar, a perdermos a maior parte do Territorio, que constituía a Monarquia Portugueza? ${ }^{109}$

Segundo Iara Lis Schiavinato (2006: 230) a partir dos acontecimentos de 1820:

A idéia de pátria articulava a terra onde se nasce, o amor à terra onde se vive, com o monarca que pactua com a localidade, a origem do próprio pacto, seu gesto de fundação, a liturgia política, a Constituição.

Da nação portuguesa à nação brasílica, realiza-se um percurso que articula cada vez mais a pátria ao território. Para o projeto político que norteará a construção do Império do Brasil, sediado no Rio de Janeiro e encabeçado pela continuidade da monarquia através do governo de D. Pedro I, a unidade territorial era pressuposto fundamental. Conforme destaca Demétrio Magnoli (1997: 88):

O poder imperial no Brasil surge como resposta à ameaça da desintegração republicana: como instrumento da unidade política e territorial. De certo modo, a centralização real e simbólica das instituições políticas substituía um (inexistente) substrato integrador social e econômico. A solução imperial para a crise representou, também, uma conciliação e um compromisso entre os princípios conflitantes do direito hereditário da Casa de Bragança e da soberania popular.

A defesa da unidade territorial conduz, para Ilmar Mattos (1994: 97, 98), "a uma desqualificação da política e a um realce da ação administrativa" que reserva "ao centro - à Coroa -, ao mesmo tempo que o justifica, um papel de gestor dos interesses dominantes que se distribuem de maneira irregular pela imensidão do território". E a

\footnotetext{
${ }^{108}$ Brasil e Portugal, ou reflecções sobre o estado actual do Brasil. Rio de Janeiro, Typographia do Diario, 1822. Bibioteca Nacional do Rio de Janeiro, Seção de Obras Raras, $(39,8,10)$.

${ }^{109}$ Idem, página 14.
} 
monarquia, neste contexto, era ressaltada como a única capaz de ordenar tamanho território, em contraposição ao "resto da América espanhola retalhado em estados diferentes" ${ }^{110}$. Inaugura-se, a partir de 1822, um Estado, centralizado no Rio de Janeiro e nos interesses de seus atores políticos, com ímpetos essencialmente territorialistas, bem como uma preocupação particular com a questão fronteiriça.

É nesse contexto que José Antônio Pimenta Bueno, Marquês de São Vicente, afirmaria que "o território do império não constitui somente a sua mais valiosa propriedade; a integridade, a indivisibilidade dele é mais a mais não só um direito fundamental, mas um dogma político. É um atributo sagrado de seu poder e de sua independência; é uma das bases primordiais de sua grandeza interior e exterior" (apud Mattos, 1994: 95).

Mas o curioso é que, se na Europa o princípio da territorialidade, ao afirmar um direito de solo em detrimento do direito de sangue, seria "portador de uma liberdade e de uma igualdade" e "anunciador de uma cidadania cuja vocação é impor-se para lá das alianças comunitárias" (Badie, 1996: 54) no Brasil ele vai se justificar pela consideração do povo como mero instrumento de garantia da integridade territorial, o que pode ser percebido nas diretrizes de povoamento das áreas fronteiriças. A formação da nacionalidade brasileira seria, assim, "obra de conquista territorial, de apropriação de espaço, de exploração do homem e da terra. De construção de uma sociedade e de um território. De uma sociedade que tinha a construção do território como elemento de identidade" (Moraes, 1988: 96) Nascida sob o estigma do territorialismo ibérico, a América portuguesa viveria um peculiar processo de emancipação causado pela vinda da Corte e pela inversão da situação colonial, que relegaria ao projeto centralizador das elites políticas um caráter essencialmente territorialista, tendo o Rio de Janeiro como centro.

${ }^{110}$ Carta de um leitor do Observador Constitucional, 1823. (apud Pimenta, 2002: 196, 197). 


\section{FONTES E BIBLIOGRAFIA}

\section{FONTES}

\section{Instituto de Estudos Brasileiros (USP)}

"Projecto para o estabelecimento político do Reino-Unido de Portugal, Brasil e Algarves, offerecido aos illustres legisladores em Cortes Geraes e Extraordinarias". Antonio D’Oliva Sousa Sequeira, 1821.

\section{Biblioteca Nacional do Rio de Janeiro}

\section{Manuscritos}

"Preparatórios no Rio de Janeiro para receber a Familia Real Portuguesa. Janeiro, 16, 1808 ". II - 35, 4, 1 .

"Requerimento de aposentadoria das casas de negocio onde residem", 1808, II 30, 24, 27.

“Mapa estatístico do Rio de Janeiro”, 1816. Manuel Pedro Gomes. Ms I - 31, 19, 11.

\section{Obras Raras}

"Exposição Analytica, e Justificativa da Conducta, e Vida Pública do Visconde do Rio Secco", 1821. 37, 17, 1.

“Brasil e Portugal, ou reflecções sobre o estado actual do Brasill”. H. J. D’Araujo Carneiro. Reimpresso no Rio de Janeiro na Typographia do Diario, 1822.

$39,8,10$

\section{Arquivo Nacional}

"Carta enviada ao visconde de Anadia, João Rodrigues de Sá e Melo, por Caetano Pinto de Miranda Montenegro, governador da capitania de Pernambuco, em 1808”. Arquivo Nacional, Fundo Ministério do Reino. Pernambuco. Correspondência do presidente da província. IJJ 237.

"Bando sobre as novas Minas das Caxoeiras de Macacú e se o povoarem as terras daquele Certão. Rio de Janeiro", 19/10/1786. Portarias/ Vice-Reinado - ANRJ, códice 73, vol. 16, fl.140. Rio de Janeiro, 19/10/1786.

"Bando sobre todas as pessoas que pertenderem levar e introduzir gados e quaisquer otras Provizoens nas novas Minas de Macacú o poderem fazer livremente". Portarias/Vice-Reinado, ANRJ, códice 53, vol 16,fl. 141. Rio de Janeiro, 23/10/1786. 


\section{Fontes Impressas}

"Abreviada demonstração dos trabalhos da Policia em todo o tempo que servio o Dezembargador do Paço Paulo Fernandes Viana". Revista Trimestral do IHGB, tomo 55, parte I, 1892.

Colecção das Leis do Brazil de 1808. Rio de Janeiro: Imprensa Nacional, 1891.

"Instrucção militar para Martim Lopes Lobo de Saldanha - Governador e CapitãoGeneral da Capitania de S. Paulo" Salvaterra de Magos, 14 de janeiro de 1775. Revista do Instituto Histórico e Geográfico Brasileiro, Rio de Janeiro, 1863.

"Memórias e cotidiano do Rio de Janeiro no tempo do rei: trechos selecionados das cartas de Luis Joaquim dos Santos Marrocos". Acervo digital da Biblioteca Nacional, Rio de Janeiro.

"Officio do Vice-Rei D. Luiz de Vasconcellos e Souza com a copia da relação instructiva e circunstanciada, para ser entregue ao seu sucessor". Revista do IHGB Instituto Histórico e Geográfico Brasileiro, n. 13, abril de 1842, tomo IV, Rio de Janeiro.

ANTONIL, André João. Cultura e opulência do Brasil. Belo Horizonte, Ed. Itatiaia/ Edusp, 1982.

CASAL, Aires. Corografia Brasílica. São Paulo, Belo Horizonte, Edusp, Itatiaia, 1976.

CUNHA, D. Luis da. Instruções políticas. Introdução e edição Abílio Diniz Silva, Lisboa, Comissão Nacional para as Comemorações dos Descobrimentos Portugueses, 2001 .

DEBRET, Jean-Baptiste. Viagem pitoresca e histórica ao Brasil. Tomo II. Belo Horizonte, Ed. Itatiaia, 1978.

DENIS, Ferdinand. O Brasil. Belo Horizonte/ São Paulo, Ed. Itatiaia/ Edusp, 1992.

LEITHOLD, Theodor von \& RANGO, L. von. O Rio de Janeiro visto por dois prussianos. São Paulo, Ed. Nacional, 1966.

LUCCOCK, John. Notas sobre o Rio de Janeiro e partes meridionais do Brasil. Belo Horizonte, Ed. Itatiaia, 1975.

MARTIUS, Carl. "No Reino das Palmeiras. Viagem do Rio de janeiro a Sumidouro, 1817”. In: E. S. Bruno e D. Riedel. A Cidade, O Mar e as Serras (ES, RJ e DF), Histórias e Paisagens do Brasil, vol.V. São Paulo, Ed. Cultrix, 1959.

MAWE, John. Viagem pelo interior do Brasil. São Paulo, Edusp/ Itatiaia, 1978. 
MORAES, A. J. de Mello. História da Transladação da Corte portuguesa para o Brasil. 1807-1808. Rio de Janeiro, 1872, Livraria da Casa Imperial (Biblioteca Nacional - Seção de Obras Raras).

O’NEIL, Thomas. A vinda da família real portuguesa para o Brasil. Rio de Janeiro, José Olympio, Secretaria Municipal das Culturas, 2007.

PRADT, M de. The Congress of Viena. London, S. Leigh, 1816.

POHL, Johann. Emanuel. Viagem ao interior do Brasil. Belo Horizonte: Ed. Itatiaia, 1976.

SAINT-HILAIRE, Auguste. Segunda viagem do Rio de Janeiro a Minas Gerais e a São Paulo, 1822. Belo Horizonte, Ed. Itatiaia, 1974.

Horizonte, Ed. Itatiaia, 2000.

- Viagem pelas províncias do Rio de Janeiro e Minas Gerais. Belo

SANTOS, Luis Gonçalves dos. Memórias para servir à história do reino do Brasil. Belo Horizonte/ São Paulo, Itatiaia/ Edusp, 1981.

SILVA, Manuel Vieira da. Reflexoes sobre alguns dos meios propostos por mais conducentes para melhorar o clima da cidade do Rio de Janeiro Rio de Janeiro: Impressão Régia, 1808.

SPIX, Johann von \& MARTIUS, Carl von. Viagem pelo Brasil (1817-1820). São Paulo/ Belo Horizonte, Edusp/ Itatiaia, 1981 (3 vols).

\section{Cartografia}

BNRJ - Biblioteca Nacional do Rio de Janeiro

Capasso, Domenico (c. 1730). "Mapa Corographico da Capitania do Rio de Janeiro", manuscrito. Mapoteca da BNRJ, ARC 023,01,001. (Catálogo Digital: referência cart542711.tif)

Leão, Manuel Vieira (1767). "Cartas topographicas da capitania do Rio de Janeiro mandadas tirar pelo Illmo. e Exmo. Sr. Conde da Cunha Capitam general e Vice-Rey do Estado do Brazil", 15 folhas, manuscrito. Mapoteca da BNRJ, CAM.02,008 (Catalogo digital: referência cart512339)

Roscio, Francisco (1777). "Carta Corographica da Capitania do Ryo de Janeyro, capital dos Estados do Brasil”, manuscrito. BNRJ, ARC.012,04,006. (catalogo digital: cart534317.tif)

"Reconhecimento do rio de Macacu e da estrada que conduz a Nova Friburgo: (Colônia Suissa)" Lith. do Archivo Militar, 1819. BNRJ ARC.003,13,026. (Catálogo digital, referência cart524755.tif)

BNL - Biblioteca Nacional de Lisboa 
Mawe, John (1812). "Travels in the Interior of Brazil, particularly in the Gold and Diamond Districts of that country by Authority of the Prince Regent of Portugal, including a voyage to the Rio de la Plata, and an Historical Sketch of the Revolution of Buenos Ayres". Londres. Mapoteca da Biblioteca Nacionalde Lisboa, Portugal (catálogo digital, n. 263)

\section{BIBLIOGRAFIA}

ABREU, Mauricio. Evolução Urbana do Rio de Janeiro, RJ, IPLANRIO/ Jorge Zahar, 1987.

- "Construindo uma geografia do passado: Rio de Janeiro, cidade portuária, século XVII”, In: Revista GEOUSP nº 7, DG/FFLCH/USP, 2000.

ADONIAS, Isa. Mapa. Imagens da Formação Territorial do Brasil. Fundação Emilio Odebrecht, Rio de Janeiro, 1993.

. Mapas e planos manuscritos no Brasil Colonial: 1500-1822. Ministério das Relações Exteriores, Rio de Janeiro, 1960.

ALENCASTRO, Luis Felipe de. O trato dos viventes. Formação do Brasil no Atlântico Sul. São Paulo, Cia das Letras, 2000.

ALGRANTI, Leila M. "Os ofícios urbanos e os escravos a ganho no Rio de Janeiro colonial (1808-1822). In: T. Szmerecsànyi (org). História Econômica do período colonial. São Paulo, Edusp/ Imesp/ Hucitec, 2002.

ALLIÈS, Paul. L'invention du territoire. Grenoble, Presses Universitaires de Grenoble, 1980.

ALMEIDA, André Ferrand. “'Arrumar as terras, os rios e os montes': os jesuítas matemáticos e os mapas do Brasil meridional, 1720-1748”. In: Manoel de Azevedo Fortes. Cartografia, cultura e urbanismo. Fernandes, Mário Gonçalves. (coord, 2006). Gabinete de Estudos de Desenvolvimento e Ordenamento do Território. Departamento de Geografia, Universidade de Lisboa, Lisboa, pp. 99-122, 2006.

ALMEIDA, Manuel Antonio de. Memórias de um sargento de milícias. São Paulo, Ed. Ática, 1982.

ANDERSON, Benedict. Imagined Communities. London/ New York, Verso, 1983.

ANDRADE, Santiago Silva de. "Morar na Casa do Rei, servir na Casa do Império". Informes de pesquisa. Revista Almanack Braziliense, n. 5, maio/2007.

ANDRADE, Tarcísio Bahia de. Paisagem e arquitetura no Rio de Janeiro. Iconografia do olhar conciliador de pintores e arquitetos. Tese de doutoramento.Escuela Técnica Superior de Arquitectura de Barcelona, Universidad Politécnica de Cataluña, 2002. 
ARAÚJO, Ana Cristina. "Um Reino, um império e uma monarquia na América. As vésperas da independência do Brasil". In: A Independência do Brasil: História e Historiografia. István Jancsó (org). São Paulo, Hucitec, 2005.

ARAÚJO, Elysio. Estudo histórico sobre a policia da capital federal. Rio de Janeiro, Imprensa Nacional, 1898.

ARAÚJO, Carlos Eduardo Moreira de. "Corrigindo os Desviantes: aconstrução do sistema prisional no Brasil - uma perspectiva comparativa Rio de Janeiro e Rio Grande do Sul, século XIX. In: Anais do $3^{\circ}$ Encontro Escravidão e Liberdade no Brasil Meridional, Florianópolis, UFSC, 2007.

ARHEIM, Rudolf. The power of the center. A study of composition in the visual arts. Berkley, Los Angeles, University of California Press, 1988.

AZEVEDO, Aroldo. Vilas e Cidades do Brasil Colonial. Boletim de Geografia nº11, FCL/USP, 1956.

BADIE, Bertrand. O fim dos territórios. Lisboa, Ed. Piaget, 1996.

BAKER, Alan. “"The Dead Don't Answer Questionnaires': researching and writing/ historical geography”. Journal of Geography in Higher Education, vol. 21, n 2, 1997.

University Press, 2003.

Geography and History: Bridging the Divide. Cambridge, Cambridge

BAKIS, Henry. Les réseaux et leurs enjeux sociaux. Paris, PUF, 1993.

BARATA, Carlos Eduardo. "Afinal!!! Quantas pessoas vieram com a corte de d. João? 1807-1808". In: Ipanema, Rogéria Moreira (org). D. João e a cidade do Rio de Janeiro: 1808-2008. Instituto Histórico e Geográfico do Rio de Janeiro, 2008.

BARBOZA FILHO, Rubem. Tradição e artifício. Iberismo e Barroco na formação americana. Belo Horizonte/ Rio de Janeiro, Ed. UFMG/ IUPERJ, 2000.

BARROS, Edval de Souza. "Proprietários rurais e Estado português em meio ao avanço da fronteira agrária escravista: a capitania do Rio de Janeiro (1763-1808). Dissertação de Mestrado, UFF, Niterói, 1997.

BÉDARD, Mario «Une typologie du haut-lieu, ou la quadrature d'un geosymbole ». Cahiers de Géographie du Québec, volume 46, n 127, abril 2002.

BEDIAGA, Begonha. "Conciliar o útil ao agradável e fazer ciência: Jardim Botânico do Rio de Janeiro - 1808 a 1860”. História, Ciências, Saúde - Manguinhos, Rio de Janeiro, v.14, n.4, out.-dez. 2007.

BERMAN, Marshall. Tudo o que é sólido desmancha no ar: a aventura da modernidade. São. Paulo: Cia das Letras, 1986. 
BERNARDES, Denis. O patriotismo constitucional: Pernambuco 1820-1822. São Paulo, Hucitec, 2002.

BESSE, Jean Marc. Voir la Terre. Six essais sur le paysage et la géographie. Arlés, Actes du Sud ENSP/ Centre du Paysage, 2000.

BICALHO, Maria Fernanda. A cidade e o império. $O$ Rio de Janeiro na dinâmica colonial portuguesa. Tese de Doutorado, DH/FFLCH/USP, 1997.

BICALHO, M. Fernanda, FRAGOSO, J. Luis \& GOUVEA, M. Fátima. O Antigo Regime nos trópicos: a dinâmica imperial portuguesa, séculos XVI-XVII. Rio de Janeiro, Civilização Brasileira, 2001

BICALHO, Maria Fernanda. "O Rio de Janeiro no Século XVIII: A transferência da capital e a construção do território centro-sul da América portuguesa". URBANA. Revista Eletrônica do CIEC/IFCH/ UNICAMP, v. 1, p. 1-20, 2006.

BOURDIEU, Pierre. Razões Práticas. Campinas, Papirus, 1997.

BRAUDEL, Fernand. O Mediterrâneo e o mundo mediterrâneo na época de Filipe II. São Paulo, Martins Fontes, 1984.

BROWN, Larissa. Internal commerce in a colony: Rio de Janeiro and its hinterland (1790-1822). University of Virginia, PHD, 1986.

BRUNO, Ernani da Silva \& RIEDEL, Diaulas (org). A Cidade, O Mar e as Serras (ES, $R J$ e DF), Histórias e Paisagens do Brasil, vol.V. São Paulo, Ed. Cultrix, 1959.

BRUNO, Ernani. História Regional do Brasil. Vol. 4. Rio e Minas. São Paulo, Ed. Cultrix, 1967.

CAPEL, H. "Geografia y arte apodémica en el siglo de los viajes". Scripta Nova. [En línea]. Barcelona: Universidad de Barcelona, Marzo de 1985, ano IX, $\mathrm{n}^{\circ} 56$. $<$ http://www.ub.es/geocrit/geo56.htm>. [05 de Marzo de 2006]. ISSN: 0210-0754.

CANDIDO, Antonio. "Dialética da malandragem". In: $O$ discurso e a cidade. São Paulo, Ed. Duas Cidades, 1993.

CAVALCANTI, Nireu. O Rio de Janeiro setecentista. A vida e a construção da cidade da invasão francesa até a chegada da Corte. Rio de Janeiro, Jorge Zahar Editor, 2004.

CARDOSO, Ciro Flamarion. Agricultura, Escravidão e Capitalismo. Petrópolis, Vozes, 1979.

CARVALHO, Marieta Pinheiro de. "Uma idéia de cidade ilustrada: as transformações urbanas da nova corte portuguesa (1808-1821)". Dissertação de Mestrado. Rio de Janeiro, UERJ, 2003.

CHIARAMONTE, José Carlos. Ciudades, Províncias, Estados: Orígenes de la Nación Argentina (1800-1843), Biblioteca del Pensamiento Argentino, I/ Ariel Historia, 1997. 
CORRÊA, Lucelinda Schramm. “As políticas públicas de imigração européia nãoportuguesa para o Brasil - de Pombal à República".Revista Geo-Paisagem. Ano 4, no 8, 2005 Julho/Dezembro de 2005. ISSN N 1677-650 X

Cortesão, Jaime (1965). História do Brasil nos Velhos Mapas. Instituto Rio Branco, Rio de Janeiro, 2005.

COSGROVE, Denis. "Observando la natureleza: el paisaje y el sentido europeo de la vista", Buenos Aires, Boletin de AGE, n. 34, 2002, 63-89.

Geography and Vision: Seeing, Imagining and Representing the World. London, IB Tauris, 2008.

COSTA, Wanderley Messias da \& MORAES, Antônio Carlos Robert. Geografia Crítica. A Valorização do Espaço. São Paulo, Hucitec, 1984.

DARBY, Henry Clifford. "Historical Geography in Britain, 1920-1980: continuity and change". Transactions Institute of British Geographers, nº, Londres, 1983.

DIAS, Maria Odila Silva. “A interiorização da metrópole”. In: C. G. Mota (org). 1822: Dimensões. São Paulo, Ed.Perspectiva, 1972.

Casa Editorial, 2005.

. A Interiorização da Metrópole e outros estudos. São Paulo, Alameda

DIENER, P. \& COSTA, M. F. Rugendas e o Brasil. São Paulo: Capivara, 2002.

DODGSHON, Robert A. Society in Time and Space. A Geographical Perspective on Change. Cambridge Studies in Historical Geography. Cambridge, University Press, 1998.

DOMINGUES, Ângela. "Dom João, príncipe esclarecido e pai dos povos, e a fundação das colônias sueca de Sorocaba e suiça de Nova Friburgo". In: Oliveira, Luis Valente de \& Ricupero, Rubens (org). A abertura dos portos. São Paulo, Ed. Senac, 2007.

ELIAS, Norbert. A socidade de corte. Lisboa, Estampa, 1987.

ELLIS, Miriam. A baleia no Brasil colonial. S. Paulo, Ed. Melhoramentos, 1968.

ERTHAL, Ruy. "A presença de dois distintos padrões de organização agrária moldando a região de Cantagalo, província do Rio de Janeiro, na primeira metade do século XIX". Revista Scripta Nova de Geografia e Ciências Sociais, Universidade de Barcelona, Vol. X, núm. 218 (34), 1/ago/2006.

ESPINDOLA, Haruf Salmen. Sertão do Rio Doce: navegação fluvial, acesso ao mercado mundial, guerra aos povos nativos e incorporação do território de floresta tropical por Minas Gerais (1800-1845). Tese (Doutorado), DH/ FFLCH/ USP, 2000.

EUFRÁSIO, Mario Antonio. A Estrutura da Teoria dos Lugares Centrais de W. Christaller. Dissertação de Mestrado, DG/FFLCH/USP, 1982. (contém tradução do 
original de Walter Christaller em alemão, "Die zentrale Orte in Süddeutschland" de 1933).

FÁLCON, Francisco C. \& MATTOS, Ilmar Rohloff de. "O Processo de Independência no Rio de Janeiro". In Carlos Guilherme Mota (org). 1822: Dimensões. São Paulo, Perspectiva, 1972.

FERNANDES, Florestan. Circuito Fechado. São Paulo, Hucitec, 1977.

FERREIRA, Orlando da Costa. Imagem e letra: introdução à bibliologia brasileira. São Paulo: Edusp, 1994.

FLORENTINO, Manolo \& FRAGOSO, João Fragoso. O Arcaísmo como projeto. Rio de Janeiro, Ed Civilização Brasileira, 2001.

FOUCAULT, Michel. Microfísica do Poder. Rio de Janeiro, Edições Graal, 2002.

FRAGOSO, João Luis. Homens de Grossa Aventura: acumulação e hierarquia na praça mercantil do Rio de Janeiro. Rio de Janeiro, Arquivo Nacional, 1992.

FREYRE, Gilberto. Sobrados e Mocambos. Rio de Janeiro, Record, 2000.

FURTADO, Junia F \& SAFIER, Neil. "O sertão das Minas como espaço vivido: Luis da Cunha e Jean-Baptiste Bourguignon D'Anville na construção da cartografia européia sobre o Brasil". In: Paiva, Eduardo França (org, 2006). Brasil-Portugal. Sociedades, culturas e formas de governar no mundo português (séculos XVI-XVIII). Ed. Annablume, São Paulo, pp 263-277, 2006.

GARCIA, Romyr C. "Nos descaminhos dos reais direitos: o contrabando na capitania do Rio de Janeiro (1770-1790)". Dissertação de Mestrado, DH/FFLCH/USP, 1995.

GOMES, Mauro Leão. "Ouro, posseiros e fazendas de café, a ocupação e a degradação ambiental da região de Cantagalo". Tese de Doutorado, Ciências Sociais, UFRJ, Rio de Janeiro, 2004.

GORENDER, Jacob. O escravismo colonial. São Paulo, Ed. Ática, 1978.

GORENSTEIN, Riva. Comércio e política: o enraizamento dos interesses mercantis portugueses no Rio de Janeiro (1808-1830). In: Lenira Martinho e Riva Gorenstein. Negociantes e caixeiros na sociedade da Independência. Rio de Janeiro, Secretaria Municipal de Cultura, 1993.

GOSCHLER, Juliana. "Embodiment and body metaphors". Metaphorik www.metaphorik.de, no . 9, December, 2005.

GOTTMANN, Jean. La politique des états et leur géographie. Paris, Armand Colin, 1952. 
GOUVEA, Maria de Fátima Silva. "Redes de poder na América Portuguesa: O caso dos homens bons do Rio de Janeiro, ca. 1790-1822”. Revista Brasileira de História, 1998, vol.18, no.36, p.297-330.

"As bases institucionais da construção da unidade. Dos poderes do Rio de Janeiro joanino: administração e governabilidade no império luso-brasileiro". In: Jancsó, Istvan. (Org.). Independência: história e historiografia. São Paulo, 2005.

HAESBAERT, Rogério. O mito da desterritorialização. Do "fim dos territórios" à multiterritorialidade. $2^{\mathrm{a}}$ ed. Rio de Janeiro, Bertrand Brasil, 2006.

HALL, Catherine. Civilising Subjects: Metropole and Colony in the English Imagination. Cambridge, Polity, 2002.

HARLEY, J. Brian. La nueva naturaleza de los mapas. Fondo de Cultura Económica, México, 2005.

HARVEY, David. Condição pós-moderna. 11 a ed. São Paulo, Edições Loyola, 2002. A produção capitalista do espaço. São Paulo, Hucitec, 2005.

HESPANHA, A. Manuel \& XAVIER, Ângela B. "As redes clientelares". In: José Tengarrinha (org.). História de Portugal: o Antigo Regime. Lisboa, Editorial Estampa, 1993.

HOLANDA, S. B. “A herança colonial, sua desagregação". In: Idem (org.) História Geral da Civilização Brasileira, tomo II, $1^{\circ}$ volume. São Paulo: Difel, 1975.

. Visão do Paraíso. São Paulo: Brasiliense, 1994.

JANCSÓ, Ístvan. "A construção dos estados nacionais na América Latina. Apontamentos para o estudo do Império como projeto". In Tamas Szmrecsányi \& José R. do Amaral Lapa (org.). História Econômica da Independência e do Império. São Paulo, EDUSP/ IMESP/ HUCITEC, 2002.

Hucitec/ Unijui, 2003. (org). Brasil: Formação do Estado e da Nação. São Paulo, Fapesp/ Hucitec, 2005. . (org.). Independência: história e historiografia. São Paulo, Fapesp/

JANCSÓ, Ístvan \& PIMENTA, João Paulo G. "Peças de um mosaico: apontamentos para o estudo da emergência da identidade nacional brasileira". In: Carlos Guilherme Mota (org.) Viagem incompleta. A experiência brasileira. São Paulo, Senac, 2000.

KARASCH, Mary. A vida dos escravos no Rio de Janeiro (1808-1850). São Paulo, Cia das Letras, 2000.

KELLY, Allison. "An expensive present: the Adam Screen in Rio de Janeiro". The Burlington Magazine, Vol. 126, No. 978, setembro, 1984. 
KURY, L "Viajantes-naturalistas no Brasil oitocentista: experiência, relato e imagem". Hist. cienc. saude-Manguinhos, 2001, vol.8 supl, p.863-880.

. "Auguste de Saint-Hilaire: viajante exemplar". Revista Intellèctus [em línea]. Rio de Janeiro: Universidade Estadual do Rio de Janeiro, 2004, ano II, vol.I. < http://www2.uerj.br/ intellectus/Anterior_2 01.htm> [15 de Febrero de 2006] ISSN: 1676-7640.

LACOSTE, Yves. Paysages politiques. Paris, Librairie Générale Française, 1990.

LAMEGO, Alberto Ribeiro. O Homem e o Brejo. Rio de Janeiro, IBGE, 1945. . O Homem e a Restinga. Rio de Janeiro, IBGE, 1946. . O Homem e a Guanabara. Rio de Janeiro, IBGE, 1964

LENHARO, Alcir. As tropas da moderação. Rio de Janeiro, Biblioteca Carioca, 1992.

LEPETIT, Bernard. Por uma Nova História Urbana. São Paulo, EDUSP, 2001.

LIRA, Larissa Alves de. "Fernand Braudel e Vidal de La Blache: Geohistória e História da Geografia". Revista eletrônica Confins, n. 2, $1^{\circ}$ semestre 2008.

LISBOA, K. M. A Nova Atlântida de Spix e Martius: natureza e civilização na "Viagem pelo Brasil”, 1817-1820. São Paulo: Hucitec, 1997.

LOBO, Eulália Meyer L. História do Rio de Janeiro: do capital comercial ao capital industrial e financeiro. Rio de Janeiro, Imbel, 1978.

LOPEZ, Emilio C. R. Festa públicas, memória e representação. São Paulo, Humanitas, 2004.

LOS RIOS FILHO, Adolfo Morales. O Rio de Janeiro Imperial. Rio de Janeiro: Topbooks, 2000.

LYRA, Maria de Lourdes Viana. "A unidade brasileira: uma questão preliminar no processo de independência”. In: Rev. Inst. Est. Bras., SP, n 34, pp. 121-138, 1992.

1994.

. A utopia do poderoso Império. Rio de Janeiro, Ed. Sette Letras,

MADERUELO, Javier. Paisaje y territorio. Madrid, Ed. Abada, 2008.

MAGNOLI, Demétrio. O Corpo da Pátria. Imaginação Geográfica e Política externa no Brasil, 1808-1912. São Paulo, Ed. UNESP/Moderna, 1997.

MALERBA, Jurandir. A corte no exílio. Civilização e poder às vésperas da independência. São Paulo, Cia das Letras, 2000. 
FGV, 2006.

. A independência do Brasil: : novas dimensões. Rio de Janeiro, Ed.

MARAVALL, José Antonio. La cultura del barroco. Barcelona, Ed. Ariel, 1993.

MARINS, Paulo Garcez. Através da rótula: sociedade e arquitetura no Brasil, século XVII a XX. São Paulo, Humanitas, 1999.

MARIUTTI, Eduardo B. Balanço do debate: a transição do Feudalismo ao Capitalismo. São Paulo, Hucitec, 2004.

MARTIN, André Roberto. Fronteiras e Nações. São Paulo, Contexto, 1992.

MARTINS, L. L. O Rio de Janeiro dos viajantes: o olhar britânico (1800-1850). Rio de Janeiro: Jorge Zahar, 2001.

MARTINHO, Lenira e GORENSTEIN, Riva. Negociantes e caixeiros na sociedade da Independência. Rio de Janeiro, Secretaria Municipal de Cultura, 1993.

MARX, Karl. O Capital. Rio de Janeiro, Civilização Brasileira, 1975.

MASSEY, Doreen. Space, Place and Gender. Minneapolis, University of Minesota Press, 1994.

MATTOS, Ilmar Rohloff. O tempo saquarema. A formação do Estado imperial. Rio de Janeiro, Access, 1994.

. "Construtores e herdeiros - a trama dos interesses na construção da unidade política”. In: Jancsó, István (org). Independência: história e historiografia. São Paulo, Fapesp/ Hucitec, 2005.

MENDES, Elizabeth de Camargo. Viajantes no Brasil: 1808-1822. Dissertação de mestrado. DH/FFLCH/USP, 1981.

MIGNOLO, Walter. The Darker Side of Renaissance. Literacy, Territoriality, and Colonization. $3^{\text {a }}$ ed. University of Michigan, 2001.

. Historias locales/ diseños globales. Madrid, Akal, 2003.

MORAES, Antonio Carlos R. Ideologias Geográficas. Espaço, cultura e política no Brasil. São Paulo, Hucitec, 1988.

Bases da Formação Territorial do Brasil. O território colonial brasileiro no "longo" século XVI. São Paulo, Hucitec, 2000.

. Território e História no Brasil. São Paulo, Hucitec, 2002. 
. "El sertón como el otro geográfico".In: Bertoncello, Rodolfo \&

Carlos, Ana Fani A. (org.) (2003). Processos Territoriales entre Argentina y Brasil. Universidad Buenos Aires, Buenos Aires, 2003.

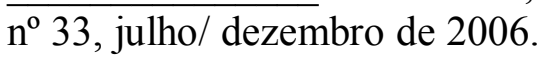

“Território, Região e formação colonial". In: Ciência \& Ambiente,

MUSSO, Pierre (org). Réseaux et societé. Paris, PUF, 2003.

NOGUEIRA, Carlo Eugenio. Nos sertões do poente: conquista e colonização do Brasil Central. Dissertação de Mestrado, Departamento de Geografia, FFLCH, USP, 2008.

NOVAIS, Fernando A. Portugal e Brasil na crise do Antigo Sistema Colonial (17771808). São Paulo, Ed. Hucitec, 1979.

OLIVEIRA, Cecília Helena L. S. “A astúcia liberal. Relações de mercado e projetos políticos no Rio de Janeiro (1820-1824)". Tese de doutorado. DH/ FFLCH/ USP, 1986.

“Tramas políticas, redes de negócios". In István

Jancsó (org). Brasil: formação do Estado e da Nação. São Paulo, Fapesp/ Hucitec/ Unijui, 2000.

OLIVEIRA, Luis Valente de \& RICUPERO, Rubens (org). A abertura dos portos. São Paulo, Ed. Senac, 2007.

OLIVEIRA LIMA, Manuel de. D. João VI no Brasil. $3^{\text {a }}$ ed. Rio de Janeiro, Topbooks, 1996.

PECHMAN, Robert Moses. Cidades estreitamente vigiadas. Rio de Janeiro, Casa da Palavra, 2002.

PEIXOTO, Léa Quintino. Os principais antigos caminhos fluminenses para as minas gerais. Niterói, Imprensa Estadual, 1951.

PIJNING, Ernst. "Contrabando, ilegalidade e medidas políticas no Rio de Janeiro do século XVIII”. In: Revista Brasileira de História, vol.21, n.42, 2001.

PIMENTA, João Paulo Garrido. Estado e Nação no fim dos Impérios Ibéricos no Prata (1808-1828). Hucitec/FAPESP, São Paulo, 2002.

POLANYI, Karl. A grande transformação: as origens de nossa época. Rio de Janeiro, Campus, 2000.

PRADO JÚNIOR, Caio. Evolução política do Brasil. São Paulo, Ed. Brasiliense, 1983. Brasiliense/ Publifolha, 2000.

Formação do Brasil Contemporâneo. São Paulo, Ed. 
RAFFESTIN, Claude. Pour une géographie du pouvoir. Paris, Ed. Litec, 1980.

RATZEL, Friedrich. "O solo, a sociedade e o Estado" In Revista do Departamento de Geografia da FFLCH/USP n ${ }^{\circ} 2,1983$.

ROCHA, Antonio Penalves. "Economia política e política no período joanino". In: T. Szmerecsànyi \& J. R. A. Lapa (org). História Econômica da Independência e do Império. São Paulo, Edusp/ Imesp/ Hucitec, 2002.

RUSSEL-WOOD, A. “Centros e periferias no mundo luso-brasileiro". Revista brasileira de História, vol. 18, n. 36, São Paulo, 1998.

SACK, Robert. Human Territoriality. Cambridge, Cambridge University Press, 1986.

SALVADOR, Frei Vicente do. História do Brasil. Weisz-Flog Irmãos, São Paulo. 1918.

SANTOS, Corcino M. dos. Relações comerciais do Rio de Janeiro com Lisboa (17631808). Rio de Janeiro, Tempo Brasileiro, 1980.

SANTOS, Douglas. A reinvenção do espaço. São Paulo, Ed. Unesp, 2002.

SANTOS, Milton. Metamorfoses do espaço habitado. São Paulo, Hucitec, 1988.

. Pensando o espaço do homem. São Paulo, Hucitec, 1997.

. A natureza do espaço. São Paulo, Hucitec, 2002a.

Por uma Geografia nova. São Paulo, Hucitec, 2002b.

SANTOS, Milton \& SILVEIRA, Maria Laura. O Brasil: território e sociedade no limiar do século XXI. Rio de Janeiro, Record, 2001.

SANTOS, Renata. A imagem gravada. Rio de Janeiro, Casa da Palavra, 2008.

SCHIAVINATO, Iara Lis. "Questões de poder na fundação do Brasil: o governo dos homens e de si (c. 1780-1830)". In: Malerba, Jurandir (org). A independência brasileira: novas dimensões. Rio de Janeiro, Ed. FGV, 2006.

SCHULTZ, Kirsten. Tropical Versailles. Empire, Monarchy, and the Portuguese Royal Court in Rio de Janeiro, 1808-1821. Nova Iorque, Routledge, 2001.

"Royal Authority, Empire and the Critique of Colonialism : Political Discourse in Rio de Janeiro (1808-1821)" Luso-Brazilian Review, Vol. 37, No. 2, Special Issue: State, Society, and Political Culture in Nineteenth-Century Brazil, 2000.

SCHULTZ, Kirsten. "A era das revoluções e a transferência da corte portuguesa para o Rio de Janeiro (1790-1821)". In: Malerba, Jurandir (org). A independência brasileira: novas dimensões. Rio de Janeiro, Ed. FGV, 2006. 
SCHWARCZ, Lílian Moritz. A longa viagem da biblioteca dos reis: do terremoto de Lisboa à Independência do Brasil. São Paulo: Cia das Letras, 2002.

. "Pagando caro e correndo atrás do prejuízo". In: Malerba, Jurandir (org). A independência brasileira: novas dimensões. Rio de Janeiro, Ed. FGV, 2006.

- O sol do Brasil: Nicolas-Antoine Taunay e as desventuras dos artistas franceses na corte de d. João. São Paulo, Cia das Letras, 2008.

SEVCENKO, N. O. "Dragões, borboletas e brasis". In: Jornal de resenhas, $\mathrm{n}^{\circ} 2$, 01/05/1995.

SILVA, Ana Rosa Cloclet da. Inventando a nação. Intelectuais ilustrados e estadistas luso-brasileiros na crise do Antigo Regime português (1750-1822). São Paulo, Hucitec/ Fapesp, 2006.

SILVA, Maria Betriz Nizza da. Cultura e Sociedade no Rio de Janeiro (1808-1822).

São Paulo, Ed. Nacional (Brasiliana), 1978.

Vida privada e quotidiano no Brasil na época de D. Maria I e D. João

VI, Lisboa, Editorial Estampa, 1993.

SIMMEL, Georg. La tragédie de la culture. Paris, PUF, 1998. . "The Stranger". In: Kurt Wolff (org.) The Sociology of Georg

Simmel. New York, Free Press, 1950.

SLEMIAN, Andréa. Vida política em tempo de crise: Rio de Janeiro (1808-1824). São Paulo, Hucitec, 2006.

SOARES, Luiz Carlos. "A indústria na sociedade escravista: as origens do crescimento manufatureiro na região fluminense em meados do século XIX (1840-1850)". In: T. Szmerecsányi \& J. R. A. Lapa. História Econômica da Independência e do Império. São Paulo, Edusp/ Imesp/ Hucitec, 2002.

SOJA, Edward. Geografias pós-modernas: a reafirmação do espaço na teoria social crítica. Rio de Janeiro, Ed. Jorge Zahar, 1993.

SORRE, Max. "Migrações e mobilidade do ecúmeno". In: Januário F. Megale. Max Sorre. Coleção Grandes Cientistas Sociais - Geografia. São Paulo, ed. Ática, 1984.

SOUZA, Candice Vidal. A pátria geográfica. Sertão e litoral no pensamento social brasileiro. Ed. Universidade Federal de Goiás, Goiânia, 1997.

SOUZA, Iara Lis Carvalho. A pátria coroada. O Brasil como corpo político autônomo. São Paulo, Ed, Unesp, 1998.

" "Imagens do Brasil: entre a natureza e a história". In: İstvan Jancsó (org.). Brasil: formação do Estado e da Nação. São Paulo: Fapesp/ Hucitec/ Unijui, 2003. 
SOUZA, Laura de Mello e. O sol e a sombra. Politica e administração na América portuguesa do século XVIII. São Paulo, Cia das Letras, 2006.

SZMERECSÀNYI, Tamas \& LAPA, José Amaral (org). História Econômica da Independência e do Império. São Paulo, Edusp/ Imesp/ Hucitec, 2002.

TESCHKE, Benno. "Dynastic Territoriality Theorizing the Westphalian System of States: International Relations from Absolutism to Capitalism". European Journal of International Relations, 2002.

VAN HOUTUM, Henk \& STRÜVER, Anke. "Borders, Strangers, Doors and Bridges" Space and Polity, Vol. 6, n. 2, 2002, p. 141-146.

VANCE JR, James E.. The Merchant's World: The Geography of Wholesaling. Englewood Cliffs, Prentice-Hall, 1970.

VENÂNCIO, Renato P. "Pobreza estrutural e pobreza conjuntural no Rio de Janeiro, 1750-1808". In: Tarcísio R. Botelho et alli. (org). História Quantitativa e Serial no Brasil - um balanço. ANPUH, Minas Gerais, 2001.

VITERBO, Sousa. Dicionário histórico e documental dos arquitectos, engenheiros e construtores portugueses. Ed. Fac-símile. Imprensa Nacional-Casa da Moeda, Lisboa, 1988.

VON CLEEF, Eugene. "Hinterland and Umland". Geographical Review, American Geographical Society, Vol. 31, No. 2 Apr, 1941, p. 308-311.

WALLERSTEIN, Immanuel. O sistema mundial moderno. Lisboa, Afrontamento, 1974.

WEBER, Max. História Geral da economia. São Paulo, Mestre Jou, 1968.

WEIGEND, Guido. "The problem of hinterland and foreland as illustrated by the port of Hamburg”. Economic Geography, Clark University, vol 32, nº 1, jan. 1956.

WILCKEN, Patrick. O império à deriva. A corte portuguesa no Rio de Janeiro (18081821). Rio de Janeiro, Objetiva, 2005. 